\title{
The Matter of
}

\section{Early Modern Female Melancholy}

By

Emma Rayner

A thesis submitted to the Victoria University of Wellington in fulfilment of the requirements for the degree of

Master of Arts

in English Literature

Victoria University of Wellington 


\section{Contents}

Acknowledgements.........................................................

Abstract................................................................. vii

Introduction: Diagnosing Melancholy..................................... 1-19

1. Female Melancholy From Within and Without

Shakespeare and An Collins.....................................................20-52

2. The Monuments Melancholy Makes

Webster, Shakespeare, Milton, and Pulter..................................54-84

3. Postlapsarian Melancholy and the Woman Poet

Lucy Hutchinson ........................................................... $85-113$

Conclusion............................................................. 114-7

Appendix......................................................................

Works Cited............................................................. 120-128 


\section{Acknowledgements}

I owe my biggest thanks to my supervisor Sarah Ross, both for her invaluable input throughout this thesis' writing, and for the opportunity to take up an MA scholarship on the "'Woe is me': Women and Complaint in the English Renaissance" project, funded by a Royal Society Te Apārangi Marsden grant. Thanks also to my family and pals for the cheering help along the way. 


\begin{abstract}
The Renaissance is often touted as the age of melancholy. For fictional personages like Hamlet as well as for writers like Robert Burton, melancholy served both as a burden and a blessing, facilitating intellectual activity at the expense of psychological and bodily comfort. Precisely because of its Aristotelean associations with brilliance, melancholy was off-limits to early modern women, who were afforded a pathology different not merely in degree but in kind to that of the male melancholic. Female melancholy was understood as an entirely corporeal illness, lacking any semblance of the creative or intellectual fecundity which its male sufferers enjoyed.
\end{abstract}

Literary critics and cultural historians have long taken the authors of early modern medical treatises at their word, and because of this, the extant scholarship on melancholy projects an overwhelmingly masculinist history of the emotion. Those scholars who have addressed the subterraneous literature of women's emotion in the Renaissance, moreover, have commonly understood female-voiced articulations of negative affect through the lens of "grief" or "sorrow". A poetics of female melancholy in the English Renaissance is thus still awaiting formulation, and it is this critical absence that I move to redress.

Putting male-authored, canonical works of literature in dialogue with the poetry of three seventeenth-century women writers, this thesis pursues the topic of a literary melancholy that is specifically female, or female-voiced. Chapter One explores the shape of female melancholic discourse in two Shakespearean texts - Hamlet and The Two Noble Kinsmen - and in the poetry of devotional poet An Collins. Chapter Two considers the telos of self-marmorisation (the female melancholic's turn to stone) first in Webster's Duchess of Malfi, Shakespeare's The Winter's Tale, and Milton's Comus, and then in the verse of Hester Pulter. Finally, Chapter Three discusses the presence of postlapsarian melancholy in the elegies of Lucy Hutchinson. All three chapters argue for the significance, the matter, of artistic representations of women's affect in a period which has traditionally seen male expressions of melancholy raised above female expressions of the same. 


\section{Diagnosing Melancholy}

Two acts into Shakespeare's most famous play, Hamlet airs the following confession to his untrustworthy friends:

I have of late, but wherefore I know not, lost all my mirth, forgone all custom of exercises, and indeed it goes so heavily with my disposition that this goodly frame, the earth, seems to me a sterile promontory; this most excellent canopy, the air, look you, this brave o'erhanging firmament, this majestical roof fretted with golden fire - why, it appeareth no other thing to me but a foul and pestilent congregation of vapours. $(2.2 .257-264)^{1}$

There are two angles of vision expressed in this, and they correspond to the melancholic's native residence between subjectivity and objectivity, sanity and insanity. Foucault suggests that beneath the apparent delirium of madness, there resides a "second delirium, which is, in a sense, pure reason, reason delivered of all the external tinsel of dementia" (91). Just so, with one eye, Hamlet can see - and does describe, richly and hypnotically - the beauty of the Globe he appraises; with the other, though, he ousts that splendor as a mere fiction. This last perspective might be the mad one, colouring everything over in greyscale and delirium (making it merely "seem" to be so), but it might just as well be Foucault's feat of "pure reason", revealing mortal man as a myopic fool, and terrestrial wonder for the flight of fancy that it is. Since he is not wholly restricted to one view over the other, Hamlet can hold these two worlds up to each other at once, and render neither

\footnotetext{
${ }^{1}$ All Shakespeare quotations hereafter are taken from The Norton Shakespeare ( $3^{\text {rd }}$ ed.). I work from the Combined Text edition of Hamlet.
} 
worth seeing. "[T] he gifted melancholic", in the words of Klibansky, Panofsky, and Saxl, "walked a narrow path between two abysses" (32) - but if any character succeeds in finding sublimity in the terrifying in-between, it is surely Hamlet.

More than any other piece of Western literature, Shakespeare's Hamlet signifies the elevation of melancholy into the ideal and masculinized condition we have come to know it as. It is melancholy that drives Hamlet's ability to realize and express his sense of acute loneliness, to gesture towards a core or essence of being which others cannot access, and to see beyond the dross of reality (albeit to yet more dross). All the things which make Hamlet the "modern subject" par excellence, in other words, seem to turn on the historically-specific melancholy that he suffers. "It is his melancholy alienation and indecision", Jonathan Flatley confirms, "that defines Hamlet as a hero and has allowed him to allegorize modern subjectivity for several centuries now" (36). The moment of Hamlet thus marks, in strokes difficult to undo, the making of the nexus between melancholy, interiority, and masculinity. But what would it mean if our conception of seventeenth-century melancholy were to stretch beyond Hamlet (the character, that is), and beyond the pale of the male?

A historically-gendered tradition is never easy to square, and the institution of melancholy is no exception. Brought into being by male physicians and intellectuals in the classical period, written into the best-known Renaissance verse and prose by male authors, and typically articulated in male-authored literature by characters or speakers of that same sex, the affective state of melancholy has from the first been designated the provenance of the educated man. Conversely, lesser forms of grief and sorrow have been reserved for women. In early modern England, mourning was an activity "necessarily left to women since it responds to the loss of an actual rather than a symbolic object, thus tying women to a material level and preventing them from reaching the sublime symbolics 
of loss accorded to the melancholic man" (Breitenberg 40). ${ }^{2}$ If women were allowed to experience melancholy over the material mourning described above, moreover, then they were afforded a pathology different not merely in degree but in kind to that of the male melancholic. Take Johann Weyer, the sixteenth-century demonologist who more or less set the tone for later cultural constructions of female melancholy when he asserted that, due to the "Frailty of the Female Sex", a Satanic form of melancholy regularly transformed women - and especially "stupid, worn-out, unstable old women" - into delusional liars (Radden Nature of Melancholy 99). Robert Burton continued the derogatory theme into the seventeenth century, locating in his influential Anatomy of Melancholy (1621) the aetiology of women's melancholy in idleness and sexual deprivation. Burton's solution? Domestication of the passions through marriage, of course $^{3}$

What philosopher Max Pensky identifies as the central dialectic of melancholy experience, however - this being the tension between "affliction and empowerment" (31) - seems uniquely applicable to the premodern woman writer's situation. Owing to the exclusionary practices of a society unwilling even to admit female-authored works to the literary playground, and apt to decry the few manuscripts which did achieve publication, women poets' common experience was one of isolation and obscurity - the duo of

\footnotetext{
${ }^{2}$ As Patricia Phillippy notes, the material praxis of mourning the dead was in the early modern period a woman's reserve:

In the absence of professional undertakers, early modern women were the most frequent and immediate attendants on bodies in death, fulfilling not only emotive rites of mourning but also the more mundane tasks of caring for the dying, washing out and winding the corpse, watching the body during its period of laying out, serving as mourners for funerals, and donning mourning garments according to cultural rules of relation, sex, and class. ("The Mat[t]er of Death" 150)

3 " [T] he best and surest remedy of all, is to see them well placed, and married to good husbands in due time, hinc illae lachrymae, thats the primary cause, $\&$ this the ready cure, to give them content to their desires" (Burton 1:416).
} 
existential qualities which attend, indeed comprise, melancholy. Alert to this parallel, Jennifer Radden writes that melancholy is a reasonable response to women's "lack of freedom, opportunity, self-expression, respect, and esteem" (Moody Minds 68). Douglas Trevor also briefly speaks to this point in The Poetics of Melancholy, concluding that "the prospect of acute isolation, coupled with their Galenically-understood dispositions, made the risk of scholarly melancholy far greater for [early modern] women" (22). Further strengthening the analogy between melancholy affect and female marginalisation, Bronwen Price notes - in a comment which maps quite directly onto Pensky's affliction/empowerment dialectic - that female-authored poetry of the early modern period tends to "Jost[le]" between self-negation and affirmation" ("Women's Poetry" 284). Women's exclusion from male discourse, Price argues, registers in the instability of their poetic speakers, who regularly assert their own feminine deficiency and modesty whilst at the same time exploiting autonomously-written verse as a vehicle for expression and enfranchisement. The woman writer soars into sublime regions, but just as often, she descends into a nadir of corporeality and self-hatred; add melancholy to the mix, and the rate of oscillation increases twofold.

And so, in light of Juliana Schiesari's statement that "we must ... recognize the hierarchical determination of who can legitimate loss and recuperate it, whose laments are heard and whose are not" (54), this thesis takes up the topic of a melancholy that is specifically female, or female-voiced. Through uncovering the ideological particularities and formal patterns within selected canonical and sub-canonical works of seventeenthcentury English literature, I ask what might distinguish the subterraneous story of female melancholy from the male version mapped below. 


\section{A brief (literary) history of melancholy}

"For most of western European history", writes Jennifer Radden in her preface to The Nature of Melancholy, "melancholy was a central cultural idea, focusing, explaining, and organizing the way people saw the world and one another and framing social, medical, and epistemological norms" (vii). This much I have hopefully established - but from whence did this prevailing mode of affect originate? One thing is certain: melancholy enjoyed an elevated status for many centuries prior to Shakespeare's dramatizing the rottenness of Denmark (and its crown prince).

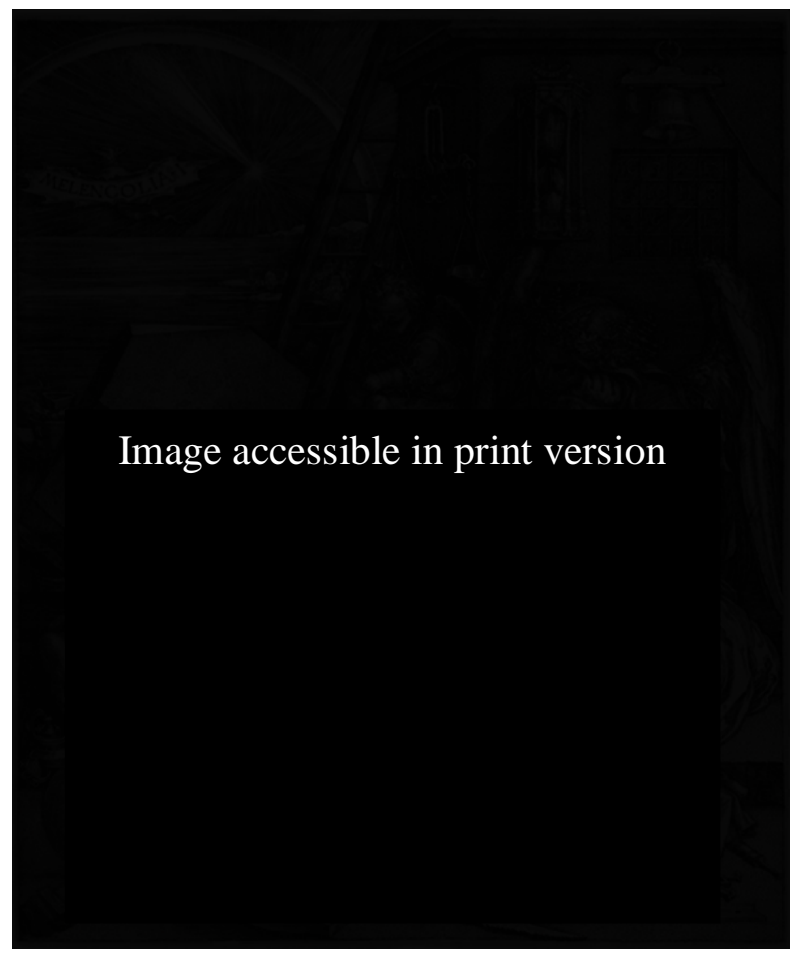

Figure 1: Albrecht Dürer's Melencolia I (1514). Note the mathematical instruments bordering the central figure.

As early as the 1480s, Aristotle's claim that "all those who have become eminent in philosophy or politics or poetry or the arts are clearly melancholics" 4 was experiencing a renaissance all of its own at the hands of European humanists. Italian Neoplatonist Marsilio Ficino, translator of both Plato and Plotinus, was particularly central to the

\footnotetext{
${ }^{4}$ As quoted in Klibansky, Panofsky and Saxl, Saturn and Melancholy, p. 18.
} 
founding of the Renaissance cult of melancholy. According to Klibansky, Panofsky, and Saxl, it was Ficino "who really gave shape to the idea of the melancholy man of genius and revealed it to the rest of Europe - in particular, to the great Englishmen of the sixteenth and seventeenth centuries - in the magic chiaroscuro of Christian Neoplatonic mysticism" (255). Ficino's address to the scholar, De vita libri tres (1480), is said to have sparked a conceptual shift which "transform[ed] the way a cadre of intellectuals claimed to value unhappiness" (Trevor 4).

Thanks to Ficino's promotion of the link between dispositional sadness and brilliance, melancholy - or rather, the claim to being so - became an assured route to selfcharacterisation as a scholar. The correlation was so marked that students were thought to live under the sign of Saturn, the melancholy planet, for the duration of their university careers (Dixon 17-18). It is this studious brand of melancholy Milton takes up in his poem "Il Penseroso" (1631), the last section of which reads as follows:

And may at last my weary age Find out the peaceful hermitage, The hairy gown and mossy cell, Where I may it and rightly spell Of every star that heaven doth shew, And every herb that sips the dew; Till old experience do attain To something like prophetic strain. These pleasures Melancholy give, And I with thee will choose to live. $(167-176)^{5}$

Promoting melancholy as the key to spiritual rest and knowledge, Milton's speaker professes his willingness to accept omniscient powers of insight as the sweet reparation for old age and solitude. ${ }^{6}$ Suggesting a familiarity with Ficino's Neoplatonist view of melancholy, Milton records at one point of his poem an ambition to

\footnotetext{
${ }^{5}$ All quotations from Milton's shorter poems are taken from the Longman edition ( $2^{\text {nd }}$ ed.).

${ }^{6}$ Because of their cold and dry constitutions, old men were thought the most susceptible to melancholy of all the social demographics. See Burton, who defines the first "secundary" cause
} 
unsphere

The spirit of Plato to unfold

What worlds, or what vast regions hold

The immortal mind that hath forsook

Her mansion in this fleshly nook ... (88-92)

In the scheme of "Il Penseroso", intellect is raised above mere matter to the point of (imagined) bodily erasure, made a means to the attainment of artistic and philosophical superiority.

By 1600, however, this indulgently-exceptionalising type of melancholy had become thoroughly modish, no longer a mark of distinction but of stereotyping done to the self. ${ }^{7}$ Jaques, the resident "Melancholy Monsieur" of As You Like It (1599), satirically catalogues melancholy's many postures as he attempts to assert a melancholy all of his own:

I have neither the scholar's melancholy, which is emulation, nor the courtier's, which is proud, nor the soldier's, which is ambitious, nor the lawyer's, which is polite, nor the lady's, which is nice, nor the lover's, which is all of these ... (4.1.10-14)

To be sure, the "scholar's melancholy" which I have until this point been discussing and which comes first on Jaques' list - continued to make its presence known into the seventeenth century (Burton, the leading proponent of scholarly melancholy in England, did not pen his Anatomy until 1621, and revised it up until his death in 1640). It was increasingly challenged, however, by the discourse of humoural melancholy which, technically, preceded it.

of melancholy as "olde age, which being cold and dry, and of the same quality of melancholy is, must needes cause it, by diminution of spirits and substance, and increasing of adust humours" (1:203).

7 "Il Penseroso" was written in the 1630s, but critics have often pointed to its pastiche-like anachronism. See, for example, Christopher Kendrick, who notes a "regressive impulse" within the poem, its "imaginary retreat into the past, into pre-Spensarian, indeed perhaps into preReformation times" (“Anachronism in 'Lycidas"”, ELH, vol. 64, no. 1, 1971, pp. 1-40), p. 22. 
Under the Hippocratic medical theory Galen advanced, the body was thought to be comprised of four humours, all of which jostled for eminence within walls of flesh. Disharmony of the humours - the dominating influence of one over the other, for reasons internal or external - was believed to be the source of all somatic illness. ${ }^{8}$ Melancholy was thus first and foremost a physiological disorder, the alleged consequence of an excess of black bile flooding the body's hydraulic system. ${ }^{9}$ Unlike the rest of the humoural illnesses, however, melancholy was also explicitly related to symptoms of mental disorder. Galen was the first to draw out the heady associations between the body's black bile and the mind's sadness, observing in his bilious patients a tendency to "exhibit fear and despondency", to "dread death and desire to die at the same time", and to fall prey to “abnormal sensory images" (Radden Nature of Melancholy 67-9). Foucault elaborates on the premodern correspondence between black bile and darkness of mood in Madness and Civilisation:

A symbolic unity formed by the languor of the fluids, by the darkening of the animal spirits and the shadowy twilight they spread over the images of things, by the viscosity of the blood that laboriously trickles through the vessels, by the thickening of vapours that have become blackish, deleterious, and acrid, by visceral functions that have become slow and somehow slimy - this unity, more a product of sensibility than of thought or theory, gives melancholia its characteristic stamp. (114)

Foucault convenes a hypnotizing cluster of images, but they are at once poetic and visceral, and aptly convey the "anti-Platonic, materialist conception of being" (Trevor 34) which humouralism engendered in Renaissance thought.

\footnotetext{
${ }^{8}$ The overwhelming physicality of the humoural complaint of melancholy is what perhaps makes "affect" a more apposite term to use in relation to it than "emotion". Like the humours, "affects are not productively examined in terms of a body-mind dichotomy; they occur neither in mind nor body but in an assemblage, network, or system that is not comprehensible in terms of its corporeal or cognitive component parts" (Flatley 14). See also Kern Paster, Humouring the Body, p. 28, and Trevor, The Poetics of Melancholy, p. 4.

${ }^{9}$ The Hippocratic corpus was in fact responsible for the coining of the term 'melancholy', which derives from the Greek melaina-kole, meaning 'black bile' (Flatley 1).
} 
By the early seventeenth century, few authors failed to allude to the body and its humours - to gesture (if only metaphorically) to the "symbolic unity" Foucault discusses in the above. Returning to Milton, we see this pained Galenic vocabulary deployed in a work as late as Samson Agonistes (1671). Suffice to say, Samson's "humours black" (600) are worlds away from the idealized representation of melancholy that features in "Il Penseroso":

Sam. All otherwise to me my thoughts portend,

That these darks orbs no more shall treat with light, Nor the other light of life continue long, But yield to double darkness nigh at hand: So much I feel my genial spirits droop, My hopes all flat, nature within me seems In all her functions weary of herself; My race of glory run, and race of shame, And I shall shortly be with them that rest. (590-8)

Given Samson's literal inability to see, he suffers the "double darkness" of blindness and divine disfavor. The affect that this dismal state of being breeds is a melancholy without the perk of genius (Samson feels his "genial spirits droop"). Milton's biblical hero continues to bewail melancholy's ruthless infection of his body and mind:

\footnotetext{
My griefs not only pain me As a lingering disease, But finding no redress, ferment and rage, Nor less then wounds immedicable Rankle, and fester, and gangrene, To black mortification. (617-22)
}

Mingling expressions of mental anguish with the vigorous actions of chronic disease, Samson ultimately succeeds in conflating the two, his mental griefs manifesting as if physical sores before - in a blanketing image - all congealing into blackness. We can well surmise that any promise of "prophetic strain" ("Il Penseroso" 174) would be cold comfort for such acute physiological and emotional suffering. Samson's griefs, he says, "[find] no redress", and certainly not in the form of scholarly pursuits. 
In the representations of melancholy Milton supplies in "Il Penseroso" and Samson Agonistes (one written at the start, one at the end of his career), the two branches of early modern melancholy are neatly illustrated. The first is Aristotelian, scholarly, and pleasurable; the second Galenic, bodily, and debilitating. Most artistic representations of melancholy are a mix of the two, phenomenal pain on the underside, intellectual jouissance on the other. ${ }^{10}$ This balance, however, must be carefully calibrated, for only at the perfect fill of black bile "is the melancholic not a freak but a genius" (Klibansky, Panofsky \& Saxl 32). Hamlet, of course, manages to achieve the latter plane of melancholic subjectivity, along with the Burtons, Donnes, and Miltons of the Renaissance. By vice of contrast, early modern women and their literary representations were typically enslaved by their bodies to freakishness.

Galenic doctrine stated that men were hot and dry of body, making them at least half-compatible with cold and dry melancholy. By the same logic, women, who were thought moist and cold of body, were also halfway to melancholy. ${ }^{11}$ Some Renaissance authorities even affirm women as being more vulnerable to the onset of melancholy than men - but invariably, they tie women to the "material level" of melancholy in order to distance female melancholy further from its genial male counterpart. In this period, Katharine Hodgkin records, women's melancholy was divorced from men's because thought more bodily: "Women in their disorders are ... emblems of the disorders of their ungovernable bodies and unruly passions, rather than of any idea that genius might be

\footnotetext{
${ }^{10}$ This split between suffering and genius continues to define modern ideas about melancholy. Consider Julia Kristeva's statement that "My pain is the hidden side of my philosophy, its mute sister" (4).

${ }^{11}$ Gail Kern Paster wittily titles one of her articles on Renaissance humouralism "The Unbearable Coldness of Female Being" (English Literary Renaissance, vol. 28, no. 3, 1998, pp. 416-440). Douglas Trevor, who claims (perhaps erroneously) that women's bodies are both cold and dry, writes that humoural models exactly conflated the female body and the aged melancholic's, thereby threatening any male sufferer of melancholy with "thermal feminization" (21).
} 
close to madness" ("Dionys Fitzherbert" 74). The early modern woman, seen as subject to her unruly humours and still-more-ungovernable womb, found her melancholy associated with sexuality and irrationality, her suffering located "in her restless and greedy body rather than her restless and creative mind" (Hodgkin "Dionys Fitzherbert" 75). "The category of genius", affirms Radden, "had no more place for women than the category of melancholy" (Moody Minds 47). The closest Renaissance woman came to the achievement of scholarly melancholy was through the lending of her gender to allegorical personifications of the emotion. ${ }^{12}$ The rest, literary-historical scholarship on the matter tells us, is silence.

\section{Making a noise}

This silence is especially striking because, as a broad topic of interest, melancholy has suffered the opposite to critical neglect. A natural candidate for multidisciplinary study, the matter of melancholy has inspired interpretations psychological, biological, historical, and cultural in the last century, especially following the publication of Klibansky, Panofsky, and Saxl's pioneering study, Saturn and Melancholy, in 1964. Not least because of the recent critical turn toward affect theory and the history of the emotions, the past two decades have seen a further increase in the production of scholarship on melancholy - so much so, in fact, that Drew Daniel begins The Melancholy Assemblage (2013) with the weary observation that "The topic of melancholy courts a suitable exhaustion at the present moment" (1). Daniel does not stop there: "one might well wonder", he writes, "whether anything could have gone unnoticed about this particular quintessence of scholarly dust" (1). What the "quintessence" of literary-historical scholarship on Renaissance melancholy sorely lacks, however, is an equivalent depth and

\footnotetext{
${ }^{12}$ Think of the long-haired figure of Dürer's Melencolia I, Milton's sage "goddess", or the popular Dame Mélancolie of contemporaneous French literature and song.
} 
diversity when it comes to gender. I mean this both in terms of the textual methodology employed and the ideological conclusions drawn in the extant literature.

Firstly, critics and literary historians have tended to occupy themselves with the same canon of texts, re-affirming the quartet of Shakespeare, Milton, Donne and Burton as a mainstay, and sidestepping the matter of either male-authored female melancholy, or women writers' appropriation of the emotion. ${ }^{10}$ These more traditional studies have flooded the field with expert analyses of Hamlet's melancholy, of Donne's argument for self-slaughter in the Biathanatos, and of the chaotic structure of Burton's Anatomy. At issue, however, is the fact that such interpretations suffer and perpetuate a certain narrowness of scope (a scope limited, perhaps, to "great works" and "great men"), and that this has resulted in an overwhelmingly masculinist and historicist view of Renaissance melancholy. ${ }^{13}$ The critical landscape has not fundamentally changed in more recent decades, despite increasingly gender-conscious critics acknowledging the importance of balancing male-dominated discussion of melancholy with equal reference to women writers. Douglas Trevor, for instance, is alert to the masculinist bent of his Poetics of Melancholy (2004), but only makes the gendered gap in his project all the more glaring when he claims that "it is rare to uncover scholars in this period, male or female, who do not claim melancholy as their predominant complexion" (6). Consigning this startling contention to oblivion with the disclaimer that "it would take a separate study to trace the emergence of female scholars and their passions in early modern England" (21),

\footnotetext{
${ }^{13}$ Recent monographs in this field include Douglas Trevor's Poetics of Melancholy (Cambridge University Press, 2004); Angus Gowland's Worlds of Renaissance Melancholy (Cambridge University Press, 2006); Drew Daniel's The Melancholy Assemblage (Fordham University Press, 2013); Mary Ann Lund's Melancholy, Medicine, and Religion in Early Modern England (Cambridge University Press, 2010); Stephanie Shirilan's Robert Burton and the Transformative Powers of Melancholy (Routledge, 2016); and Erin Sullivan's Beyond Melancholy: Sadness and Selfhood in Renaissance England (Oxford University Press, 2016).
} 
Trevor goes on to dedicate chapters to Spenser, Shakespeare, Donne, Burton, and Milton.

In recent decades, feminist scholars have moved to correct the balance, producing numerous shorter articles and longer studies which address women's experience of sadness and sorrow in the Renaissance. ${ }^{14}$ Of these, Juliana Schiesari's The Gendering of Melancholia: Feminism, Pyschoanalysis, and the Symbolics of Loss in Renaissance Culture (1992) remains the closest precedent for my own project, constituting as it does the first sustained investigation into women's exclusion from the Western tradition of melancholy. Schiesari's book is an invaluable resource: its author's interest, though, lies with continental European writers rather than with English ones, and as the book's subtitle would suggest, Schiesari engages a psychoanalaytic approach which occasionally forces literary symbols through a Freudian hermeneutic. A prolonged literary and theoretical exploration of female melancholic complaint in the English Renaissance is thus still to be formulated, and it is this lacuna that my thesis aims to partly redress.

Prior to mounting this exploration, it is necessary that I do some diagnostic work. Melancholy has, from its earliest incarnation in Classical Greece, presented a definitional quandary as to which emotional states and aetiologies it encompasses or excludes. Robert Burton, always a case in point, claims in The Anatomy of Melancholy that "Proteus himselfe is not so divers, you may as well make the Moone a new coat, as a true character

\footnotetext{
${ }^{14}$ For shorter pieces, see Eardley's article on Hester Pulter ("'Saturn [whose aspects soe sads my soule]': Lady Hester Pulter's feminine melancholic genius", New Ways of Looking at Old Texts, IV: Papers of the Renaissance English Text Society, 2002-2006, ed. Michael Denbo, ACMRS, pp. 239-254); Angela Bullard on Mary Wroth ("Love Melancholy and Creative Inspiration in Mary Wroth's Pamphilia to Amphilanthus", Sidney Journal, vol. 33, no. 2, 2015, pp. 81-102); and Sharon Alker and Holly Faith Nelson's "Memory, Monuments, and Melancholic Genius in Margaret Cavendish's Bell in Campo", Eighteenth Century Fiction, vol. 21, no. 1, 2008, pp. 1336. For monographs on grief, see Lesel Dawson's Lovesickness and Gender in Early Modern Literature (Oxford University Press, 2008); Elizabeth Hodgson's Grief and Women Writers in the English Renaissance (Cambridge University Press, 2015); and Speaking Grief in English Literary Culture, ed. Margo Swiss and David A. Kent (Duquesne University Press, 2002).
} 
of a melancholy man; as soone finde the motion of a bird in the aire, as the heart of man, a melancholy man" (1: 401). There is no better testament to Burton's claim than the Anatomy itself, which in its three hefty volumes does a remarkable job of expanding, rather than reducing into manageable shape, the protean idea of melancholy. Burton was not the last to define the affect-cum-illness of melancholy largely according to its indefinability. Modern readers may be familiar with Freud's proviso at the beginning of "Mourning and Melancholia" (1917) that "even in the field of descriptive psychiatry", melancholia "takes on various clinical forms[,] the grouping together of which into a single unity does not seem to be established with certainty" (243). Julia Kristeva makes a similar disclaimer at the beginning of Black Sun (1981): "I am trying to address an abyss of sorrow, a noncommunicable grief" (3). The debate about the status of melancholia as a distinct sub-type of depression in the current DSM-5 continues to speak to the impossibility of defining melancholy with reference to a specific cause or set of causes. ${ }^{15}$

Because "feelings of melancholy [can] blur into dull despair, elegiac states, nostalgia, and ennui” (Radden Moody Minds 15), the sheer flexibility of melancholy as a diagnosis and descriptor for affective states of seemingly all kinds is striking. For Shakespeare's Ophelia, melancholy follows on the heels of paternal death and a lover's betrayal; for Webster's Duchess, from fraternal assault and (supposed) familial slaughter; for Hester Pulter, from political and maternal loss; for An Collins, from a devout dissatisfaction with earthly joys and toys. These bases of grief are various, but in nearly all cases, melancholy is the chosen name for the reactive state at hand. This is due, in large part, to the complex merging of sadness and grief with melancholy from the fifteenth century onwards, of which the outcome could not but be

\footnotetext{
${ }^{15}$ See, for example, Gordon Parker et al., "Issues for DSM-5: Whither Melancholia? The Case for Its Classification as a Distinct Mood Disorder", Am J Psychiatry, vol. 167, no. 7, pp. 745-7.
} 
a singularly complex affective condition of the soul, in which the subjective and transitory emotion of mere 'grief' was combined with brooding withdrawal from the world and with the gloom, verging on sickness, of melancholy in the emphatic sense. (Klibansky, Panofsky \& Saxl 231) ${ }^{16}$

Likely because of the multiple cultural discourses informing it, early modern melancholy boasted the myriad nuances which made it such a useful umbrella term for sadness in this period. But though Renaissance-era melancholy is, in the literature, apt to bleed into the states of circumstantial grief, religious sorrow, and lovesickness, it retains its distinctiveness - its status as a "singularly complex affective condition" quite apart from transitory grief - in the following key respects.

The "objectless" nature of melancholy has proven the sole constant in the history of the malady, from Hippocrates and Aristotle through to the arbitrating bodies of twentyfirst century psychiatry. The Anatomy is no exception, Burton mentioning on one occasion the melancholics who, though they grieve still, do so "without any evident cause" (1:388). I want to make an immediate qualification at this juncture, however, regarding the potentially-misleading implication of the term "objectless melancholy". "Objectless" is a negative descriptor, suggesting the total absence of any identifiable cause of melancholy affect. But whilst it may be true that the melancholic person typically struggles straightforwardly to identify the cause of their woe in the manner Burton describes, this difficulty is not the result of the cause's absence so much as of its excess. An undefined or ill-defined (even a co-opted) loss is amenable to expansion and distortion; once liberated from the shackles of strictly proportionate mourning, it becomes "elusive and unbounded" (Radden Moody Minds 15). The object is not in melancholy

\footnotetext{
${ }^{16}$ Cf. Douglas Trevor: "Expressions of sadness and melancholy are [in the Renaissance] in and of themselves potentially indistinguishable" (15).
} 
missing, then, so much as it is made global and unspecific. Radden, addressing Marsilio Ficino's commentary on melancholy, explains further:

When Ficino says that the melancholic fears everything, he identifies a state he believes is caused by humoural imbalance, the scholarly life and temperament, and so on. But this state pervades all of its subject's experience, and thus it is about nothing, because it is about everything. (Moody Minds 184)

By reason of the paradoxical absence and excess of the melancholic object, some twentyfirst century experts on melancholy prefer to replace "loss" with "lack", a term bettersuited to the signification of the great range of causes - "internal and external, perceptible and imperceptible" (Radden Melancholic Habits 131) - which inform this enigmatic mode of affect.

Another essential criterion for the diagnosis of melancholy is duration. Freud says of typical grief that "We rely on its being overcome after a certain lapse of time, and we look upon any interference with it as useless or even harmful" (244). Not so with melancholia, which persists far beyond the accepted period of object-based mourning, and - because the object is swollen to mean, as Radden says, everything - often presents as a disproportionate or even a melodramatic response to the objectively-assessed "lack". Sheer longevity is not absolutely necessary to the pathology of melancholy. ${ }^{17}$ In terms of the female melancholy addressed in this thesis, however, duration does prove a defining element. For female speakers, the assertion of one's own protracted or acute mourning constitutes a political statement. When a writer Lucy Hutchinson uses her poetry to reject the culturally-sanctioned, terminable, material kind of mourning Breitenberg refers to, she accepts the chronic condition of melancholy, and in so doing moves to inject her sadness with far greater gravitas than it was afforded by her culture. In the course of this

\footnotetext{
${ }^{17}$ Burton, for example, refers in the Anatomy to a "transitory Melancholy" (1:136) which disappears nearly as fast as it manifests, and Freud makes a similar gesture in "Mourning and Melancholia" ("The fact that [melancholia] passes off after a certain time has elapsed without leaving traces of any gross changes is a feature it shares with mourning" [252]).
} 
transformation, the lost object (if it existed to start with) is excavated of content, as melancholia proper is carved out. "The affect of melancholia both affirms and denies loss, insisting on there being a loss while denying the loss of the 'what' in the object ... In simpler terms, loss itself becomes the dominating feature when the 'content' of loss has been emptied" (Schiesari 47). For women who are always bound to mourning a distinct something or someone else, and never for longer than the prescribed period, the wallowing that Schiesari describes - this mourning, for mourning's sake - is a contrary assertion of solipsism and exceptionalism.

Freud's object-cathexis hypothesis supports this claim. In mourning, Freud asserts, the desire which was previously to be projected onto the lost object is left unmoored, not to be displaced onto another person or ideal. It subsequently boomerangs back into the ego, where the self effectively identifies with or as the lost object: "Thus the shadow of the object fell upon the ego, and the latter could henceforth be judged by a special agency, as though it were an object, the forsaken object" (Freud 249). In melancholia, then, circumstantial mourning is not necessarily erased but extenuated, its orbit of affect expanded beyond the original object of loss to hug the universal theme of mortality. Loss, emptied of its original content (which may well have been reconciled within the psyche in the usual terminus of mourning), thereby becomes a heuristic to loftier introspection. Jonathan Flatley muses on melancholy's ability to illuminate the self in this way: "[Melancholia] is a practice that might, in fact, produce its own kind of selfknowledge" (3).

This self-knowledge is, I argue, best mapped through a comparative textual method, and in what follows, I parse women-authored expressions of female melancholy alongside those authored by canonical by male writers. I do so not to assert the relative value of one over the other, but rather to put female-authored texts and feminist literary criticism in 
dialogue with male-authored works and ideas. ${ }^{18}$ As Myra Jehlen proposes, "Comparison reverses the territorial image along with its contained methodology and projects instead, as the world of women, something like a long border" (585). Such active revision of the very shape of the women's writing tradition allows women, artistic or otherwise, "no longer to be seen as floating in a man's world but as a coherent group, a context in themselves" (Jehlen 576). In the niche realm of scholarship on female melancholy, Juliana Schiesari is a champion of Jehlen's "radical comparativism", choosing in The Gendering of Melancholia not to "restrict" herself to texts authored by women, and seeking in that to "encourage a revisionist understanding of the canon itself" (x). ${ }^{19}$

As my first experiment in this comparative approach, Chapter One discusses the shape of female melancholic discourse in two Shakespearean texts - Hamlet, and the coauthored Two Noble Kinsmen - and then in the poetry of mid-seventeenth century writer An Collins. This first chapter also introduces the religious or spiritual sense of melancholia. The residual effect of melancholy's medieval antecedent, the sin of acedia, is summarised in the devout Collins' refusal to allow her melancholy the same kind of uninhibited expression as Ophelia and the Jailer's Daughter. In both Shakespeare and Collins, however, melancholic discourse points to the same apparently-absent crux of interiority. This is a particularly surprising finding in the case of Collins' poetry, which because participating in the private, confessional mode, is formally allied to the qualities of authenticity and personality.

\footnotetext{
${ }^{18}$ See Jehlen, writing in 1981: "Our world apart, our female intellectual community, becomes increasingly cut off even as it expands" (577).

${ }^{19}$ This project involves the letting-go of gender as our fundamental interpretive category; only then can we "be freed of the constraining picture of [women writers] working in the shadow of the dominant male writers of their day" (see Betty Schellenberg, The Professionalisation of Women Writers in Eighteenth-Century Britain [Cambridge University Press, 2005], p. 82). Elizabeth Hodgson argues for the same in Grief and Women Writers in the English Renaissance (see page 15).
} 
From the missing matter of female melancholic speech, Chapter Two turns to probe the telos of self-marmorisation (of enmattering) that recurs in much seventeenthcentury drama and verse. The monument, I argue, is an inherently-liminal figure which, boasting its own special agency, aids the female character's or poetic speaker's plight to make of women's material mourning a tribute to melancholy. Surveying first the manner in which a trio of male-authored, dramatic characters (Webster's Duchess of Malfi, the Lady of Milton's Comus, and Shakespeare's Hermione) become stone in order to preserve their chastity and honour, I then address the alchemical development of the marmorisation trope in the poetry of Hester Pulter.

The third and final chapter returns to the theme of religious melancholy to read the poetry of Puritan writer Lucy Hutchinson. I understand Hutchinson's "Elegies", the sequence of poems she wrote following the death of her husband, as exemplars of a uniquely postlapsarian form of melancholy. Postlapsarian melancholy is a qualification of typical religious melancholy in that for its sufferer, belief (in the Fall from Paradise) is what generates a permeating dissatisfaction with the earthly realm. Hutchinson's ardent elevation of original bliss makes her present and future not worth living, and the individualism of her Protestant faith makes her dangerously solitary. As a consequence, her "Elegies" show the beginnings of melancholy's untethering from the body to become the pervasive, allegorical, poetic mood that later (secular) generations of writers would pick up.

All three chapters work to rectify the status of women's melancholy in seventeenth-century literature, to prove the significance - the matter - of representations of women's sadness in a period which has, traditionally, raised expressions of male melancholy above female expressions of the same. 


\section{Female Melancholy from Within and Without}

In these singularities, in this apparent impropriety, a deep sense is hid ... at last, when her self-command is altogether gone, when the secrets of her heart are hovering on her tongue, that tongue betrays her; and in the innocence of insanity she solaces herself, unmindful of king or queen, with the echo of her loose and well-beloved songs ...

- Goethe, Wilhelm Meister's Apprenticeship, 1795-6

Goethe's description of Ophelia, spoken by the eponymous hero of his novel, throws up a number of pertinent questions regarding the nature of the heroine's mad discourse in Hamlet. What is the "deep sense" that can be detected amidst Ophelia's fragments of song, and yet not deduced? How, too, is the sincerity of the girl's speech to be judged when her "tongue betrays her", thus identifying her as a figure of echo in madness - as the repeater of songs sung before - rather than a bearer of original subjectivity in her own right?

Such matters of substance and authenticity trouble not only Ophelia's speech, but also that of the Jailer's Daughter in The Two Noble Kinsmen (1613-14). Notwithstanding differences of genre and social class, Shakespeare and Fletcher's greensick maiden has long been dubbed a recursion of Hamlet's tragic heroine, particularly in view of the "mad scenes" so climactic to both plays. But though Ophelia's and the Jailer's Daughter's performances in these scenes are abundant in pathos - successful, to be sure, in conveying the general state of love melancholy - the specific discourse through which their grief is played out does not facilitate the expression of subjective feeling per se. Left not to speak 
properly their "heart[s]" but to mediate others' songs, Ophelia and the Jailer's Daughter are restricted in their melancholy to a speech which is heteroglossic rather than monologic, other-referential rather than self-revealing. It is because of their mad discourse's relative evacuation of selfhood that Ophelia and the Jailer's Daughter are so easily reduced to type. It is for this reason, too, that their melancholy is made vulnerable to aestheticisation in the mouths of observing characters.

If the discourse of Shakespeare's female melancholics is left distinctly open, then the poetry of women writer An Collins invites the opposite diagnosis. Collins, whose single poetry collection Divine Songs and Meditacions (1653) was published during the "general freeing up of discourse during the Civil War period" (Gottlieb xi), announces her melancholy disposition at the beginning of her book. Unlike the dramatic mad speech of fictional melancholics Ophelia and the Jailer's Daughter, Collins' confessional verse is characterized by a markedly self-contained poetic lexicon. A comparison of these two disparate discourses of female melancholy thus forms the basis of this chapter. In arranging this contrast, however, I mean to avoid the elevation of Collins' "women's writing" above Shakespeare's ventriloquizing efforts according to the arbitrary measure of sincerity. Consequently, my argument moves toward (and perhaps finally away from) the offering of yet another dialectic to the literally-divisive critical interpretation of the brilliant man's disease: that of melancholy from within, and melancholy from without.

\section{Mad talk}

This chapter's discursive and, as such, deconstructive preoccupation reflects the centrality of speech and its related concepts - expression, complaint, rhetoric - to early modern formulations of women's sadness. Leading sixteenth-century scholar Timothie Bright returns time and again to the symptom of interrupted speech in his Treatise of 
Melancholie (1586), whilst French physician Jacques Ferrand claims in his treatise on erotomania (1610; transl. 1640) that love melancholy "stop[s] the Nerves that serve for Speech" (211). The loudest voice in the fray, however, belongs to Robert Burton, who in the Anatomy of Melancholy forges an arbitrary but potent link between women's melancholy and raving complaint. ${ }^{20}$ In a section reserved for the address of "Maides, Nunnes, and Widowes Melancholy" - a section appended, intriguingly, to the Anatomy's third edition - Burton writes that female melancholics "pine away, void of councell, apt to weep, and tremble" (1:415):

Many of them cannot tell how to expresse themselves in words, or well tell what to make of their sayings ... [they] cannot againe tell how, where or what offends them, though they be in great paine, agony, and frequently complaine, grieving, sighing, weeping and discontented still ... (1:415-6)

Burton also offers silence as an alternative manifestation of female melancholia: "they will not spake," he claims, "make answere to any question, but are almost distracted, madde, or stupid for the time, and by fits" (1:416). For Burton, then, melancholy occasions in the female sex either an inarticulate flow of words (contained within the accommodating form of the "complain[t]"), or else no words at all. Both verbal manifestations, of course, denote unreason or semantic nothingness, thereby supporting Burton's theorisation of women's melancholy as lacking any kernel of genius.

Even Burton, however, concedes that women's melancholy might be more deeply felt than it is clearly heard. ${ }^{21}$ It may be that Burton's nuns, maids, and widows “cannot tell how to express themselves in words" or plainly "will not spake", but their inarticulacy does not necessarily amount to shallowness of feeling even in the Anatomy's short treatise

\footnotetext{
${ }^{20}$ Burton also claims that women's melancholy "is not so permanent as other melancholy" $(1: 415)$

${ }^{21}$ Burton stops himself soon after the quoted extracts: "But where am I? Into what subject have I rushed? What have I to doe with Nuns, Maids, Virgins, Widows? I am a bachelor myself, and lead a Monasticke life in a College, nae ego sane ineptu qui hac dixerim [I am truly a very unfit person to talk about these subjects]" (1:417).
} 
on the subject. Silence can be loaded; unintelligibility can trace a silhouette of the speaker's interior landscape even as it obfuscates the content of that shadowy form. We learn this much from Hamlet, whose very pronouncement of having "that within which passes show" (1.2.85) advertises in vagueness the semiotic stuff that he chooses not to illuminate. $^{22}$

This dual-voiced quality is not unique to the language of the pathological melancholic. To some extent, all mad discourse shares in the tendency to self-obscuration. With language "the first and last structure of madness" (Foucault Madness and Civilisation 94), a subject's - and most certainly a fictive, literary subject's - degree of madness is measured by the comprehensibility, or rather the incomprehensibility, of the linguistic signs that they produce. If, as Foucault writes, the mad subject's "explo[sion]" of signs (101) does not align with the immediate circumstances in which those signs are uttered, if appropriate referents are not to be found in fictive reality, then the social reader of sanity is impelled to deem such discourse mad. This is not because said discourse is necessarily devoid of meaning, but because it has been unmoored from an inter-subjective space in which signifiers are accessible to all parties. It has become "nothingness" (Foucault 101) to all but the mad speaker.

But though the gap between signifier and signified is characteristic of all forms of madness, the distance between the two is further stretched in melancholy. Because the melancholic subject struggles to identify their own object of loss, two discursive routes are open to them. One is complete silence - what Julia Kristeva calls "asymbolia" (9) and the other, its opposite: an utter proliferation of signs that lead nowhere (Pensky 28). Upon reading the Anatomy, we realize that Burton's neverending prose traces a quest for

\footnotetext{
${ }^{22}$ Cf. T.S. Eliot: Hamlet 'is full of some stuff that the writer could not drag to light" ("Hamlet and His Problems" 124).
} 
meaning, a searching for the seat of melancholy (or for the self more generally). But he never gets to that crux, and we the reader are diverted instead down innumerable digressive paths which do not lead us to the source of loss plaguing the Anatomy's rambling narrator. What vindicates the genial melancholic's failure to penetrate to the heart of his own sadness, however, is the high-minded discourse he is able to construct in the meantime, the intellectual feats he performs whilst rifling through his psyche for said lost object. Burton can be described as an exceptionally philosophical speaker because he shapes a discourse which sufficiently attaches, if not to specified objects of loss, to melancholy objects of contemplation which contain nearly as much - if not, in fact, more - meaning to mine. Whether it be the example of Democritus, the precepts of Tully, or the writings of Lucian, Burton draws from an impressive repository of historical-literary knowledge in order to vaunt his own scholarly intellect.

Melancholy maidens Ophelia and the Jailer's Daughter, on the other hand, are permitted none of the learned melancholic's privileges. They are locked instead into a dramatic situation which places them before both on-stage and off-stage voyeurs, and they are denied by their author(s) either the consciousness of mind or the verbal room to engage in a self-exploration which, to put it plainly, makes sense. For these female melancholics, the last tenuous thread connecting subjectivity to sign is lost. They operate instead as conduits for a speech so void of allusion to their psychologies that their physical appearances and reported behavior must act, via substitution, as the feminized and aestheticized frame of reference through which to understand (and, in the process, make typical, flatten) their melancholic woe. 


\section{Books of quotations}

Deep into The Two Noble Kinsmen, the Doctor offers his opinion on what ails the Jailer's Daughter. "Tis not an engrafted madness", he says, "but a most thick and profound melancholy" (4.3.39-40, emphasis mine). As applies to much of what the quackish Doctor offers his female patient in the way of diagnosis and cure, however, this observation is open to dispute - not least because the Jailer's Daughter's melancholic speech is, in fact, highly grafted. Carol Thomas Neely, analyzing the speech of Shakespeare's mad characters in her influential 1990 essay, names this quality "quotation":

The characteristic speech [of madness] is both something and nothing, both coherent and incoherent ... Shakespeare's language of madness is characterised by fragmentation, obsession, and repetition, and most importantly by what I will call "quotation", which might instead be called "bracketing" or "italicization". The mad are "beside themselves": their discourse is not their own. (323) $)^{23}$

Though I wholly agree with Neely's elaboration as above, the Derrida-inflected "citation" seems to me an even more fitting term with which to head such definitions of the melancholic's patchwork discourse. It is only appropriate to analyse highly polyphonic speech - regardless of its historical period of production - via the vocabulary of deconstruction. Derrida, articulating his principle of citation in "Signature, Event, Context" (1972), advances that every written sign (or "mark") is untetherable from its immediate context, and thus amenable to grafting elsewhere. There is, a priori, "no experience of pure presence, but only chains of differential marks" (Derrida 319). The applicability of this comment to all speech acts is debatable, but engaged in relation to the discourse of the early seventeenth-century theatre's leading melancholic women, Derrida's emphasis on semiotic lack bears scrutiny. As little more than a mosaic of

\footnotetext{
${ }^{23}$ Cf. Jonathan Goldberg: "The Shakespearean text is all motion; endless grafting, staying and going at once, a text whose slippages align it with the text the stars create in their endless commentary on the rise and fall of things, a text that duplicates the world and outstrips it in its generativity" (Voice Terminal Echo 131).
} 
cultural references and communally-inspired activities, Ophelia's and the Jailer's Daughter's dramatic dialogue actively realizes "the possibility of extraction and citational grafting which belongs to the structure of every mark, spoken or written" (Derrida 320).

I will now consider two specific instances of this kind of heteroglossia, beginning with the following section of Ophelia's mad speech:

\author{
OPHELIA By Gis and by Saint Charity, \\ Alack and fie for shame, \\ Young men will do't if they come to't - \\ By Cock, they are to blame. \\ Quoth she, "Before you tumbled me, \\ You promised me to Wed." \\ He answers - \\ So would I ha' done by yonder sun \\ An thou hadst not come to my bed. \\ (4.2.58-66)
}

Notable about this particular lyric is its effect of citation within citation. ${ }^{24}$ In the course of an already proverbial ditty, Shakespeare elects to have Ophelia explicitly disclose herself as a ventriloquist of voices which are only as particular - or rather, as allegorical - as their gendered pronouns would imply. Speaking both for "she" and "he", a couple no less representative than Adam and Eve, Ophelia stretches her voice an allegorical situation, and so loses particularity as a properly psychological character. As R.D. Laing comments in The Divided Self, "in her madness there is no-one there ... She has already died. There is now only a vacuum where there was once a person" (212). Though neither Ophelia nor the Jailer's Daughter suffer any shortage of lines, those lines are given over to the reiteration of cultural artifacts - premade forms, in essence, which hold metonymic power, but very little idiosyncratic worth. Even if the two female melancholics alter a word or two of the songs they borrow in order to contextualize them to a minimal degree,

\footnotetext{
${ }^{24}$ The Jailer's Daughter does the same with "George Alow” (3.5.58).
} 
they as speakers depend always on the structure of the other, on that which exists beyond them and certainly beyond the dramatic universe of the play they inhabit. The Jailer's Daughter is not lying, then, when as she readies herself to sing proper - as sure a dramatic harbinger of female madness, it would seem, as wanton hair - she declares "I'll never say a word" (3.4.18).

The Jailer's Daughter occupies exactly this state of symbolic silence when The Two Noble Kinsmen's ship conceit is performed. Noting the disordered state of his 18year-old daughter, the Jailer and an accompanying cast of male characters join in on the madness:

DAUGHTER [to JAILER] Come hither; you are a wise man. FIRST FRIEND [aside to SECOND FRIEND] Does she know him? SECOND FRIEND [to FIRST FRIEND] No, would she did.

DAUGHTER [to JAILER] You are master of a ship?

JAILER Yes.

DAUGHTER Where's your compass?

JAILER Here.

DAUGHTER Set it to th'north,

And now direct your course to th'wood, where Palamon

Lies longing for me. For the tackling,

Let me alone. Come, weigh, my hearts, cheerily!

ALL Ugh, ugh, ugh!

'Tis up! The wind's fair! Top the bowline!

Out with the mainsail! - Where's your whistle, master?

BROTHER Let's get her in.

JAILER Up to the top, boy.

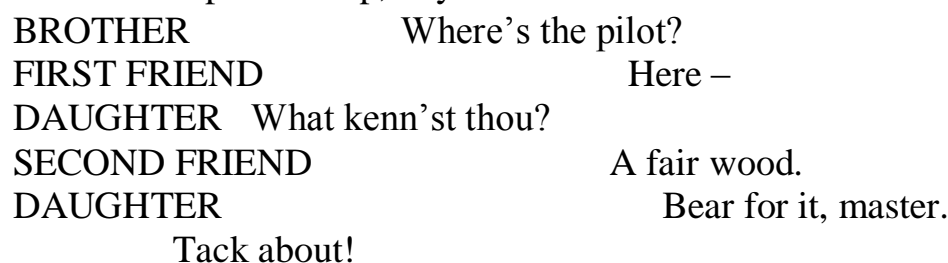

[sings.] When Cynthia with her borrowed light, etc.

Exeunt.

(4.1.140-153)

One might expect that participation in dialogue with other onstage players would expedite the melancholy speaker's self-expression. Similarly to Ophelia's distracted to-and-fros with Claudius and Gertrude in Hamlet, however, dialogue in the Jailer's Daughter's 
delusion works not to carve a reciprocal space in which each party anticipates and responds to the other's verbal offerings, but rather to veil further the young woman's individual subjectivity by presenting her desire as archetypal. The male characters, because intent on enabling and theatricalizing the Jailer's Daughter's madness, allow her mad langue to run rampant.

In this scene as elsewhere in the play, the Jailer's Daughter is confined to the communication of erotic disorder, bound by the play's discursive praxis to a performance of bawdiness. The ship mirage is firm evidence for this interpretation, approaching the status of a citation in its familiarity to early modern audiences. Robert Reed expounds on the typicality of the Jailer's Daughter's hallucination: "Such erotic illusions [were] generally believed to be the most natural expression of a maiden's demented mind, once it is no longer capable of repressing its secret and most elemental desires" (97). The paradox here is that the Jailer's Daughter's deepest desires - desires which surely, by definition, resist representation - are in the play translated for her into a figure appropriate to the cultural coupling of female virginity and erotomania. Accordingly, the ship scene draws from the realm of cultural mores first to classify the Jailer's Daughter as a greensick virgin, and then to add a number of bumbling patriarchal representatives who, recognizing the structure of her hallucination, cruelly compound it - in the hopes, one might surmise, that the young woman might utter a phrase that is bawdier still, or lead a sexual role play that is not quite so metaphorically-realized as the ship farce. ${ }^{25}$

First and foremost, then, the overt performativity of the ship scene succeeds in making a flimsy mockery of the Jailer's Daughter's melancholy. Equally, it hides her speech within a dialogic melee of others' voices and bodies. Both she and Ophelia lose

\footnotetext{
${ }^{25}$ It is essentially sexual role-play, of course, that the Doctor later prescribes as the cure for the Jailer's Daughter's lovesickness (see TNK 4.3.63-92).
} 
their speaking "I" amidst the communal activities that their discourse enacts, whether that be the physical play of the ship conceit, Ophelia's references to other "daughter[s]" (4.5.42, 168), or the Jailer's Daughter's verbally-conjured image of a collective of madwomen "boil[ing] like a gammon of bacon that will never be enough" (4.3.33-4). In such self-othering invocations of the female collective, a space is stamped out aurally for the cultural, and the madwoman's spoken citations increasingly populate that space. In the process, the subjectivity of the female melancholic recedes yet further, the psychological source of madness becoming ever more inscrutable and disembodied.

It is precisely for this reason that Ophelia and the Jailer's Daughter sound so very alike at the height of their melancholy mania. Both dipping into the same discursive melting-pot to attain their "snatches" (Ham. 4.4.176) of songs, Shakespeare's female melancholics undergo a process of intertextual de-individuation when heard in concert. ${ }^{26}$ As fictive characters, the performers of a fragmented cultural language of female complaint, Ophelia and the Jailer's Daughter inhabit others' words, and others' words inhabit them - to the extent that, in the theatrical setting, the only aspect of their characters which emerges as truly "essential" is the material instrument of the actress's (or, even more problematically, the Elizabethan boy-actor's) physical voice. ${ }^{27}$ The onus is placed on the performer billed to play Ophelia or the Jailer's Daughter to mold their given lines into anything remotely distinctive, to append the signs that exist outside of the playtext's language. ${ }^{28}$

\footnotetext{
${ }^{26}$ The Jailer's Daughter claims to be able to sing "Bonny Robin”, one of Ophelia's ditties (TNK 4.1.109).

${ }^{27}$ Katherine Mansfield seems to hit upon the centrality of the actress playing Ophelia in a diaryentry critique of Hamlet: "Mad scene. If one looks at it with a cold eye is really very poor. It depends entirely for its effect upon wispy Ophelia" (202).

${ }^{28}$ Amelia Worsley explains further: "By withholding language, Ophelia makes the relationship between her outward appearance and interiority difficult to read. She absents herself from the tradition of verbally drawing attention to the disjunction between what she feels and what she
} 


\section{Melancholic citation}

This reading of Ophelia and the Jailer's Daughter's discourse is not novel. Ophelia, in particular, has commonly been interpreted as an index of social reality rather than as a psychologically-specific character in her own right (Lopez 29). Literary historians have expended significant energy in tracing many of her speech's specific citations back to originary sources, or if not, to larger cultural phenomena active during the plays' dates of composition (see tables A \& B, appendix). ${ }^{29}$ But the theoretical argument for citation as a defining aspect of Shakespeare's melancholic female discourse tends to terminate with this assertion of Ophelia's culturally-metonymic function, with Jeremy Lopez's conclusion that "As both a textual and a theatrical phenomenon, any modern Ophelia stands in for a woman - or a kind of woman, or a group of women - that the culture at large cannot, or will not, or is notably preoccupied not to, imagine and represent". ${ }^{30}$ If, however, we apply to their mad discourse the symptomology of early modern melancholy, then Ophelia's and the Jailer's Daughter's discursive propensity to "engraft" their melancholy is published as a distinctively melancholic exercise.

Upon first hearing, Ophelia's and the Jailer's Daughter's mad speech would appear to wholly invite the Anatomy's gendered diagnosis of rhetorical excess and insensibility. To endorse this diagnosis, however, would be to ignore the citational method that structures the discourse of Shakespeare's lovesick maidens. For Ophelia's

says to other characters, and in this, she enacts a tacit refusal to privilege her offstage audience above her onstage one" (525).

${ }^{29}$ See, also, Alison A. Chapman for a theological interpretation of Ophelia's songs ("Ophelia's 'Old Lauds': Madness and Hagiography in 'Hamlet', Medieval and Renaissance Drama in England, vol. 20, no. 1, 2007, pp.111-135); Douglas Bruster on the Jailer's Daughter's discourse as a venting of the play's unconscious ("The Jailer's Daughter and the Politics of Madwomen's Language", Shakespeare Quarterly, vol. 46, no. 3, 1995, pp. 277-300); and Dorothy M. Norris for an analysis of the Saint Charity oath ("Shakespeare and Saints' Oaths", The Shakespeare Association Bulletin, vol. 7, no. 3, 1932, pp. 149-151).

${ }^{30}$ Lopez makes this comment to preface his contrary argument for Ophelia's specificity as a dramatic character (see "Reviewing Ophelia", p. 29). 
and the Jailer's Daughter's citational bent places them squarely in the corner of the intellectual male melancholic - where abides, not incidentally, Robert Burton himself. Douglas Trevor, Ruth A. Fox, and others have persuasively argued that a vital component of Burton's melancholic persona as filtered through the Anatomy is his compound discursive method. ${ }^{31}$ Aptly classified as a compendium or encyclopedia, the Anatomy of Melancholy is a veritable Eliot's "Wasteland" for the seventeenth century. In fulfilling his ambitious project to anatomize melancholy, to cut it up and fit it together once more, Burton cites upwards of 1200 other authors across the volumes of his magnum opus, mediating and containing these (male) voices of authority within a rigorously-defined and reiterated formal framework. ${ }^{32}$ Burton is not unaware of his borrowings, admitting in the Anatomy's first volume that "tis all mine and none mine" (1:11), and subsequently likening his compositional method to the feeding habits of a parasitic insect: "a Bee gathers Wax and Hony out of many Flowers", he muses, "and makes a new bundle of all" $(1: 11)$.

In view of Burton's light handling of the matter, one may be at a loss as to exactly what it is about informational extraction that so conjures the disconsolate mood of melancholy. For the aspiring Aristotelian, however, the discursive method of quoting other brilliant men - or of identifying with them pseudonymically, as Burton also moves to do with his nom de plume "Democritus Junior" 33 - is a rhetorical strategy that both sustains and advertises one's own melancholy subjectivity. Recall Jaques' remark that "the scholar's melancholy... is emulation" ( $A Y L$ 4.1.10-11). In pseudo-neurological terms, melancholics were thought to possess superior faculties of memory because of the

\footnotetext{
${ }^{31}$ See also Mark Breitenberg ("The Anatomy of Melancholy is itself a compilation of other texts on the subject" [35-6]) and Drew Daniel, The Melancholy Assemblage (from p.166 onwards).

${ }^{32}$ Ruth A. Fox counts 1250 (18).

${ }^{33}$ Democritus, as the story went, anatomised beasts in an effort to discover the seat of melancholy (Burton 1:16).
} 
refining effects of black bile (Dixon 72). When galvanized to intellectual purposes, this hyper-memory all but assured the remembering subject's place in the melancholy tradition, allowing him to practice the skill of imitation so valued by humanist scholars. The act of reiterating melancholic content thus became, for Burton and other scholarly melancholics of his generation, a way to pronounce and preserve the affective state of melancholy.

Citation is tantamount to playing hide-and-seek with one's subjectivity at the best of times: the referee exchanges his or her voice for the authority of their source, and in doing so, moves to the margins of their own discourse. Certainly in the Anatomy, searching for the melancholy selfhood of Burton alone proves an archaeological project, for he as compiler-mediator is forced to write a unique self around the deinvidividualising references that comprise his discourse. Even if we accept the proposition that consciousness can be "structured like a collection of sententiae" (De Grazia 71), therefore, it must be stated that the scholarly melancholic's subjectivity is in large part an archival phenomenon. Sifting through existing material, Burton makes a "bundle" of the dialogic offerings of other consciousnesses, and places it where his own consciousness would be. The Anatomy thus positions the authentically-mourning individual further behind the written word, to be glimpsed only at the margins of the page. ${ }^{34}$ Indeed, at points of the Anatomy, Stanley Fish has noted, Burton all but disappears (322).

\footnotetext{
${ }^{34}$ Cf. Douglas Trevor's discussion of margins and marginality throughout The Poetics of Melancholy, and especially in the chapter on "Robert Burton's Melancholic England": "Burton's discovery, in the act of writing and rewriting his book, is that the scholarly self is a marginal one" (149).
} 
All citational language is melancholic to a certain degree, the lost context of the adopted utterance analogous to the lost or missing object so often associated with modern and, indeed, premodern definitions of melancholy. ${ }^{35}$ For the genial melancholic, however, quotation is a rhetorical technique like any other, its purpose being the demonstration of learning done in an institutional setting. It may be that the vast majority of Burton's words in the Anatomy are outsourced, but it is also true that the Western intellect speaks through them; there is significant cultural capital in that. Burton's quotational method puts him in dialogue with, and ultimately defines him as, one of the great discursive talents in the Western melancholic canon. Likewise, Hamlet's association with "words, words, words" (2.2.189) affords his character a bibliophilic authority which raises esoteric complaint to a philosophical register. ${ }^{36}$ Ultimately, the melancholy scholar's exhibition of intellectual knowledge reifies his individual scholasticism, and individual scholasticism reifies melancholy humour.

Despite their being allowed to articulate citational discourse, Ophelia and the Jailer's Daughter have no recourse to the respectable and, in its peculiar way, substantial subjectivity of humanist thinkers like Burton and the fictive Hamlet. Shakespeare's madwomen are from the first restricted to the frenzied speech of the love melancholic because, long before Burton and his Anatomy, objectless grief was thought too psychically complex for the female mind and frame. Ophelia and the Jailer's Daughter hence find the content of their citations limited to the stuff of popular ballads, proverbs, and stories. These are discourses anchored to notably oral $u r$-contexts which refer not to the recovered texts of classical authors, but to a relegated society of early modern women

\footnotetext{
${ }^{35}$ Refer to this thesis' introductory material on "objectless" melancholy, pp. 15-16.

${ }^{36}$ A critic like Hardin Craig goes so far as to suggest that Hamlet reads his "To be or not to be" soliloquy directly from the book he is directed to hold ("Hamlet's Book", The Huntington Library Bulletin, no. 6, 1934, pp. 17-37).
} 
with only the verbal medium at their disposal, and male-centred plaints with which to fill it. ${ }^{37}$ Such a female langue, shut off from what Gilbert and Gubar term the "exclusiveness of a (masculinist) linguistic code" (528), works to typify all women's speech acts not in an enfranchising way - not, as in Burton's appeal to male authorities, to afford the speaker entrance to a gentleman's club of melancholic identity - but to evince women's ontological alienation from the language found in books.

One could argue that, for this reason, the subtext of cultural exclusion underlying Ophelia's and the Jailer's Daughter's lines makes their heteroglossic speech more sincerely melancholic than that of the male. Not only is their discourse equivocal and other-referential, but it lacks as well authoritative (and, in many cases, identifiable) sources at the end of its lines of signification. The female characters' words lead, in effect, to nowhere, as the loss of individual subjectivity occasioned by language-surveilling forces raises around their speech a pathetic superstructure, a web of implications and darknesses, which locates true meaning (and mourning) without that narrowly-referential lexicon.

\section{Dramatic form, female (in)expression}

To what extent is the very form of drama responsible for this caricature-view of female melancholic subjectivity? Properly addressing this question would require me to enter into the fraught debate about dramatic interiority in the early modern period, or, going further still, to join the postmodernists in destabilizing the category of a secret, inward self at its ahistorical base. For now, though, it will suffice to isolate Jonathan Goldberg's claim that "the [early-modern] individual derived a sense of self largely from external

\footnotetext{
${ }^{37}$ See Sandra Clark: "The traditional, or folk ballad, was commonly transmitted through women's singing" (103); "The ballad bemoaning the woman's lot from personal experience is not uncommon [in the early modern period]" (115).
} 
matrices" (James I 86). Goldberg's comment seems overly deconstructive when applied to a character like Hamlet, who communicates an early modern "cris[is] of authenticity" (Maus 32), a questioning of the role of the social in forming subjectivity. Goldberg's notion of a sense of self derived from external matrices is, however, highly compatible with the female melancholic's discursive characterisation.

Significantly, the most identifiably-poetic forms employed within the Renaissance play, the soliloquy and the monologue, are unavailable to Ophelia and the Jailer's Daughter once madness sets in proper. ${ }^{38}$ The citational quality of the female duo's discourse, furthermore, serves to de-individualize their characters and to excavate their speech of meaning. And because drama foregrounds the seen, the performative, and the verbally-pictorializing over the silent subjective, the female melancholic's unspoken woes quickly decrease in import as her visibly-suffering mind and body replace them as spectacle. This is where Goldberg's notion of "external matrices" becomes of use. It is not only that Shakespeare's female melancholic lacks the verbal tools to communicate her own affect; it is that she is surrounded by a network - a matrix - of characters whose own voices move to supplant hers. Quotation having already ravaged the female melancholic's sentiments, her substance-lacking speech is then populated by the aestheticizing and diagnosing words of onstage Others. The commentary of the unknown Gentleman in Hamlet is exemplary in this sense:

She speaks much of her father, says she hears There's tricks i'th' world; and hems, and beats her heart, Spurns enviously at straws, speaks things in doubt, That carry but half sense. Her speech is nothing, Yet the unshaped use of it doth move

\footnotetext{
${ }^{38}$ This is particularly important in the case of the Jailer's Daughter, who prior to and even during her descent into madness is bestowed an exceptional number of soliloquies for a Shakespearean female character. For more on this, see Michael Wagoner, "The Dramaturgical space of Solo Scenes in Fletcher and Shakespeare", Shakespeare Bulletin, vol. 35, no. 1, pp. 97118.
} 
The hearers to collection: they yawn at it And botch the words up fit to their own thoughts Which, as her winks and nods and gestures yield them, Indeed would make one think there might be thought, Though nothing sure, yet much unhappily. (4.2.4-13)

The unruly metre of this passage - lines ranging from a truncated nine syllables to an over-spilling eleven - mimics the transaction of word for meaning that its content suggests. A signifier missing or obfuscated in Ophelia's discourse is accounted for instead by her "hearers", who by their dubious discretion "botch the words up to fit their own thoughts", and so defuse the female speech act of its force.

By reading "prett[iness]" (Ham. 4.2.41, TNK 4.3.25) and "daint[iness]" (TNK 3.5.72) into female melancholy, the onstage audiences of Ophelia and the Jailer's Daughter effectively wedge their partial commentary between the real audience and the singing, speaking madwoman, presenting a vision of selfhood different to what the female melancholic presents verbally. In both plays, the spectating dramatis personae take on the role of auteurs, co-collaborating with the playwright to augment the basic (that is, the citational) dimension of the female melancholic's "profound melancholy" (TNK 4.3.44) with their extraneously-poeticizing sentiments. ${ }^{39}$ That other characters take a central role in producing meaning - and, to an extent, the interiority of characters onstage - in a theatrical context is not the problem, exactly. Issues arise when the use of dialogue towards dramatic characterisation turns into misrepresentation of the character at hand.

Nowhere is this kind of collective glossing more evident than in The Two Noble Kinsmen 4.1 and Hamlet 4.4. These scenes contain analogically-constructed unscenes

\footnotetext{
${ }^{39}$ Consider also the way in which Marcus responds to Lavinia's rape and dismemberment in Shakespeare's Titus Andronicus, with a questionable determination to speak for her (and, indeed, to make poetry out of her suffering): "Shall I speak for thee? Shall I say "tis so?" (3.1.33).
} 
(that is, reported but not theatrically-represented accounts) which detail Ophelia's and the Jailer's Daughter's riverside wanderings. ${ }^{40}$ Gertrude's speech from Hamlet is a wordpicture saturated with poetic beauty, containing many of the images and associations which have come to define the aesthetic reception of Ophelia over the centuries.

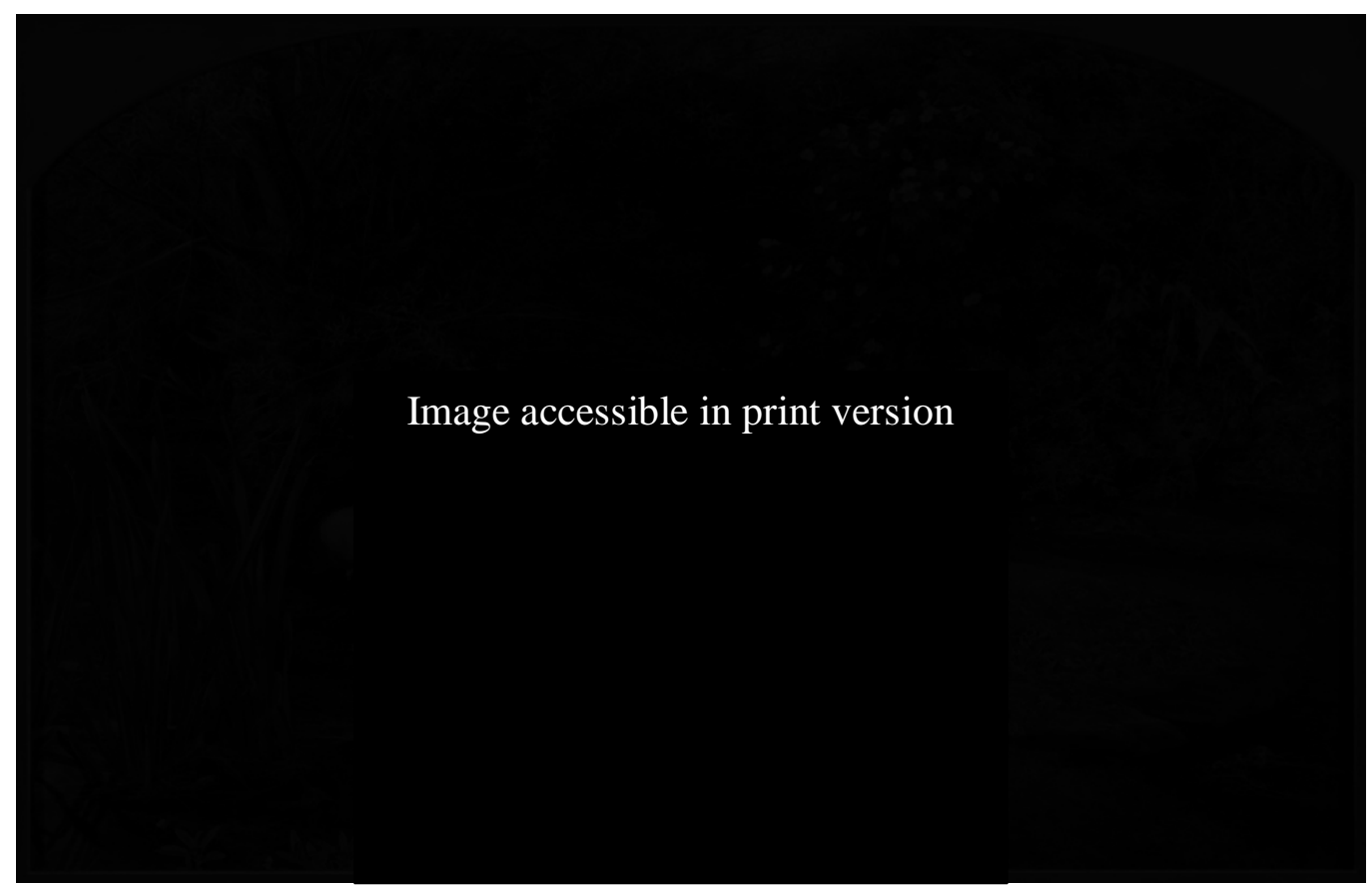

Figure 2: Gertrude's speech, further painted: John Everett Millais' "Ophelia", 1851-2.

For my purposes, however, the material details of Gertrude's speech (dead men's fingers, willows, and water) are not so pressing as the "snatches of old lauds" (4.7.176) that Ophelia is described as singing as she sinks to her death. Re-citing as her skirts drag her below water, Ophelia's empty discourse is central to her mad characterisation even as her character ceases to be. But the meta-citational quality of Gertrude's speech (Getrudecites-Ophelia-cites-lauds) actually reinscribes the skeleton-like frame of discourse left by Ophelia's citation with pathetic and personalized meaning. Ophelia thus dies in pitiable

\footnotetext{
${ }^{40}$ The term "unscene" comes from Marjorie Garber, " "The Rest is Silence': Ineffability and the 'Unscene' in Shakespeare's Plays", Ineffability: Naming the Unnameable from Dante to Beckett, ed. Peter S. Hawkins and Anne Howard Schotter, AMS Press, 1984, pp. 35-50.
} 
woe, meaning located anthropomorphically in the affective environment that Gertrude constructs outside of her melancholic consciousness.

The Wooer's speech in The Two Noble Kinsmen 4.1 plays on the meta-citational quality of the unscene in much the same way:

WOOER She sung much, but no sense; only I heard her
Repeat this often: "Palamon is gone,
Is gone to th'wood to gather mulberries -
I'll find him out tomorrow."
(4.1.66-73)

Alternating direct quotes with overstated description ("her careless tresses a wealth of bulrush rounded"; "methought she appeared like the fair nymph"), the Wooer continues to speak the Jailer's Daughter's part in his male voice, regularly attributing the reported words to their female source: "Then she talked of you, sir"; "Then she sung"; "to [rings of rushes she] spoke" (4.1.76-89). Clearly, the pathetic dialect in which the Wooer and Gertrude are fluent helps to obscure the madwoman's subjectivity by constructing a version of it anew, a counterfeit interiority which is located far outside the original speaker's physical or mental frame of reference. In consequence, the female melancholic's true voice floats further beyond our ken. The play audience is left not just to traverse the citational structure of Ophelia's and the Jailer's Daughter's discourse, but to surmount an interpretive matrix of commentary to reach even the hypothetical concept that an embodied melancholy might lie beneath the surface presentation.

In viewing such unscenes as the above, the audience member or critic is inevitably directed toward conclusions of aesthetic beauty over those of psychological complexity. Consider Marvin Rosenberg's fascinating compilation of the words most often applied to 
Ophelia's mad-scenes in historical reviews, which offers a taste of the female melancholic's reception by stage critics. Bringing together descriptors to the tune of "angelic", "chaste”, “demure", “eerie”, “enchanting”, “ethereal”, "girlish”, "lyrical”, “pliant", "poetical”, and "unaffected" (240), Rosenberg's list supports a history of (maleauthored) Hamlet scholarship that has tended to judge of Ophelia's melancholic discourse solely according to its girlish pathos. The best-known member of this camp is surely A.C. Bradley, who remarks in Shakespearean Tragedy that any analysis of Hamlet's lovesick maiden "seem[s] almost a desecration" (134). Overwhelmed by the "pathetic beauty" of Ophelia's characterisation and death (which leaves no room, in his interpretation, for “deep tragedy" [134]), Bradley's critical lens is clearly one coloured by the discursive manipulations of onstage characters. Trapped at the level of interpretation that has been dictated by Gertrude, Claudius, Laertes, and the random Gentleman, Bradley is unable as well as unwilling - to access even the cultural-citational space which hints at the deeper malaise of the "melancholizing" (Burton 1:19) female performer.

\section{Collins and confession}

Might a less-arbitrated form of expression than that permitted within the stage-play make a genuinely self-referential female melancholy possible? No representation of emotion is unmediated (representation is an inherently distancing act), but it remains that some literary forms are more amenable to self-expression than others. One would expect this to be especially true of poetry, and of confessional poetry most particularly. In confession, there is a greater linearity between the speaking "I" and the spoken utterance than in the dramatic context. The directness of the confessional mode thus makes it an attractive choice for writers who seek to distil in their works "an unmediated subjectivity, an authentic expression of authorial self' (Felski 83). This is where An Collins' poetry 
collection, Divine Songs and Meditacions, emerges as a central item of comparison within my discussion of female melancholic discourse.

Upon first reading, it might appear that the poetry of a little-known woman writer of the 1650s offers nothing but differences to the dramatic verse of the world's bestknown Elizabethan playwright. For all their contrasts, however, the two share a common discursive framework for the transmission of female melancholy: song. But Shakespeare and Collins utilise their lyrics to very different ends. I have already suggested that Ophelia and the Jailer's Daughter are not "within" their mad lyrics. Many of the fragments of song and proverb which compose the madwomen's discourse, Shakespeare and Fletcher take directly from the balladeer's mouth. Few attendees of the early modern playhouse, for example, would have been unacquainted with songs such as the "Bonny Sweet Robin" ballad that Ophelia partly mediates (4.2.179), or the "Willow, Willow" ditty that the Jailer's Daughter directly references (4.1.80). ${ }^{41}$ Not only does the authorial importation of these extant cultural forms speak to the difficulty of ventriloquizing female madness and melancholy, but it insistently defers authority to a cultural milieu where language is very much "an object to be perceived, reflected upon or related to" (Bakhtin 286). Rather than crafting lyrics for Ophelia and the Jailer's Daughter sui generis, Shakespeare and Fletcher bury subjectivity within a dense grid of pre-existing meanings, contexts, and voices. The devotional lyrics held within An Collins' single poetry collection, on the other hand, are of a different kind. Far from being porous texts contaminated by overmuch

\footnotetext{
41 "Willow, Willow" is also sung by Desdemona in Othello (4.3.38-52). For more on the songsharing of Shakespeare's girlish characters, see Amanda Eubanks Winkler, "O Let Us Houle Some Hoary Note": Music for Witches, the Melancholic, and the Mad on the SeventeenthCentury Stage, Indiana University Press, 2006, pp. 92-3.
} 
reference, Collins' divine songs mount a persuasive argument for a closed discourse in which language is present only from within, and by faith.

Collins announces herself as subject to "Clouds of Melancholy" at the very beginning of her book. ${ }^{42}$ The poet then invites her reader to share in the following autobiographical detail:

So (to be briefe) I spent my infantcy,

And part of freshest yeares, as hath been sayd

Partaking then of nothing cheerfully

Being through frailty apt to be afraid,

And likely still distempered or dismaid,

Through present sence of some calamity

Or preconceipt of future misery. ("The Discourse" 15-21)

The "frailty" mentioned mid-way through this passage requires some explanation, for unique to the Divine Songs' affective landscape is Collins' twinning of her dispositional melancholy with her unspecified, but often invoked, bodily disability. ${ }^{43}$ It is "through frailty" that Collins comes to "be afraid", and so prone to distemper, dismay, and prophetic dread. ${ }^{44}$ In fixing her melancholy temperament to her chronic physical illness in this way, Collins effectively locates all objects of loss within the radius of her own mind and body, thereby entrapping the Divine Songs' reader within the exclusive frame of reference that she raises around her verse. The fact that the Divine Songs is the sole historical record attesting to its author's existence only aids in this effect, as the absence of other biographical or artistic sources allows Collins' voice to live, for all intents and purposes, within this text alone. The collection's thematization of spiritual resilience

\footnotetext{
${ }^{42}$ I quote from Gottlieb's edition of Divine Songs and Meditacions, "The Preface", line 99.

${ }^{43}$ For more on Collins' disability, see Susannah B. Mintz, "An Collins and the Disabled Self", An Collins and the Historical Imagination, ed. W. Scott Howard (Routledge, 2014, pp. 53-70). ${ }^{44}$ Cf. Milton, "Il Penseroso": "Till old experience do attain / To something like prophetic strain" (173-4).
} 
renders Collins' discourse more insular still, making it a veritable act of hermeneutic sacrilege for the reader to step outside the text in search of extrinsic frames of reference.

Collins' explicit prioritisation of the inward over the external makes her a fitting ambassador for the virtues of early modern confessional verse. Helen Wilcox has written of how a "heightened consciousness of personal religion" through the first half of the seventeenth century "led to a newly intense stress upon private discourse with the divine, by means of meditation, personal dialogue with God, prophetic and other visionary inspirations, and poetical expression of intimate relationships between God and the individual believer" (160-1). Collins' poetry reflects this renewed emphasis on the inward, her confessional mode of speech sponsoring melancholic utterances which, rather than referring to worldly texts and persons, insistently defer to authorities accessible only from within. "Another Song [Having restrained discontent]" expresses this preference for things "Internall" without equivocation:

Looking to outward things, I found Not that which Sorrow might abate, But rather cause them to abound Then any Griefe to mitigate Which made me seek by supplication Internall Peace and Consolacion. (7-12)

The hermetic structure Collins raises around her emotional state invites comparison with Mikhail Bakhtin's view of poetic language:

The poet is not able to oppose his (sic) own poetic consciousness, his own intentions to the language he uses, for he is completely within it and therefore cannot turn it into an object to be perceived, reflected upon or related to. Language is present to him only from inside, in the work it does to effect its intention, and not from outside, in its objective specificity and boundedness. (286, emphasis mine) 
Just as Collins accuses "outward things" of endangering the purity of her "internall ornaments", ${ }^{45}$ Bakhtin presents subjective intention as incompatible with the "outside" of language.

Collins' aversion to all things extraneous applies especially to her poetic style. Encountering Collins' verse for the first time, one cannot but be struck by its plainness. As Danielle Clarke and Marie-Louise Coolahan remind us, however, plainness too is a formal choice (146). In the Divine Songs, it signals Collins' antipathy to any kind of "counterfeit content" (Stewart 176), and her religiously-inflected commitment to "simplicity as a linguistic virtue" (Wilcox 162). Collins presents herself in the Divine Songs as a champion of poetic asceticism, claiming a female modesty for her writerly persona, and advertising her poems on the bases of their superior authenticity and veracity. Near the beginning of her collection's first poem proper, "The Discourse", Collins apologises to her "pious" reader for her poetry's lack of artifice:

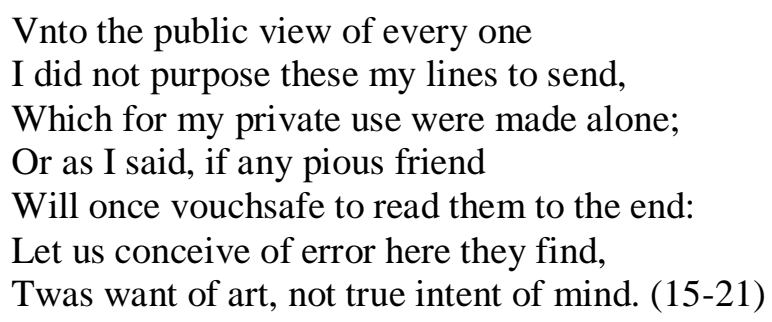

This is an apology in presentation only. It is clear that Collins considers her poetry's "want of art" to be its major drawcard, too, an artlessness which abolishes the usual rhetorical and metaphorical barriers standing between conceit-ridden verse and the communication of truth. Collins is a typical devotional writer in this regard, her renunciation of artistic complexity in exchange for divine communion aligning her ethos

\footnotetext{
${ }^{45}$ See Collins' "A Song declaring that a Christian may find tru Love only where tru Grace is", line 93.
} 
with that of poets like George Herbert. ${ }^{46}$ Recall Herbert's famous argument for poetic minimalism in "Jordan (I)":

Who says that fictions only and false hair

Become a verse? Is there in truth no beauty?

Is all good structure in a winding stair?

May no lines pass, except they do their duty

Not to a true, but painted chair? (1-5)

Just as the Word of the Bible was believed to speak directly and immediately to its reformed audience, Collins insists that her verse - like Herbert's - "plainly say[s] / My God, My King" ("Jordan [I]" 15). ${ }^{47}$ As may be clear, however, this is a different kind of "truth" to the personal. Whether poetic plainness equates to affective honesty in Collins' poetry is a fraught matter, and one I turn to address now.

Collins' early admission of her melancholic history primes her reader for a verse autobiography which will fully confess that melancholy subjectivity. To be sure, this subjectivity does receive expression at points - as in, for example, "Another Song (The Winter of my infancy)", where Collins places her affective state at the centre of metaphor:

My Aprill was exceeding dry, therfore unkind;

Whence tis that small utility I look to find,

For when that Aprill is so dry,

(As hath been spoken) it doth betoken

Much scarcity.

Thus is my Spring now almost past in heavinesse The Sky of pleasure's over-cast with sad distresse For by a comfortlesse Eclips Disconsolacion and sore vexacion, My blossom nips. (16-25)

Even in this poem, though, Collins' confession of "sad distresse" is contained within a verse form whose regular metre and rhyme are at odds with emotional upset. The above

\footnotetext{
${ }^{46}$ Helen Wilcox has firmly fitted Collins into the devotional tradition inaugurated by Herbert: see "The 'finesse' of Devotional Poetry: An Collins and the School of Herbert", An Collins and the Historical Imagination, ed. W. Scott Howard, Routledge, 2014, pp. 71-86.

47 "Any but the plainest human words would tamper with, or even dangerously mystify, the divine Word itself" (Wilcox 162).
} 
is about as explicit an expression of melancholy affect that is to be found in the entirety of the collection. Though it would be entirely justifiable for Collins to allow her chronic illnesses (one physical, one spiritual) to redouble each other rhetorically, what becomes clear upon reading the Divine Songs is that her poetic speaker is loath to debase herself by indulging in excessive complaint. This stoical impulse first makes itself known in "The Preface", where Collins" "seemingly desolate condition" is by providence made "most delightful" (1). Because of myriad voltas like this - turns which see woe banished by divine consolation - Collins' explicit expressions of melancholy are eclipsed by religious sentiment nearly as soon as they are aired.

Collins' preference for verbal restraint around the topic of personal affliction becomes more polemical as the Divine Songs progresses. By the time we reach "Another Song exciting to spirituall Mirth", our speaker has risen to cautioning those who "faint / With complaint" that they "ad to their afflictions, / And amplify the same" (22-6). Likewise, emotional forbearance is the stated goal of the early poem "The Discourse", for according to Collins,
'Twere to no end, but altogether vain, My several crosses namely to express, Words of pitty would no griefe release, But rather aggravate my heaviness, Who ever chose my crosses to conseale Till to my griefe they would themselves reveale.

(78-85)

Driving Collins' refusal to surrender to melancholic moan is her equation of such behaviour with anti-Christian indulgence. ${ }^{48}$ This stance seems a puritanical defense against the accusation of acedia (meaning "lack of care"), the medieval precursor to early modern religious melancholy. The supposed corollary of solitariness and long hours spent

\footnotetext{
${ }^{48}$ See Femke Molekamp: "aspects of Stoicism were absorbed into both Catholic and Protestant doctrine" (126).
} 
poring over scripture, acedia was a common diagnosis for European monks during the middle ages. According to thinkers like Aquinas, the monk who allowed his acedia to triumph over his spirit cast God into shadow, and brought suicide into view. "Dejection and acedia", wrote John Cassian as early as 420 AD, "generally arise without external provocation ... they often harass solitaries, and those who have settled themselves in the desert without any intercourse with other men" (qtd. in Rubin, "Melancholy" 80). Collins seems to have experienced precisely the solitary circumstances that Cassian and other commentators believe to be causally related to acedia, and perhaps because of that, her poetry records her efforts to avoid the nihilistic end-stage of spiritual melancholy that other Renaissance writers and characters readily lingered in (and, in the example of Donne and his Biathanatos, motioned to defend). Collins may be "a woman with poor health ... shut off from the world", but she flips this circumstance so that it becomes "a protection and aid to creativity rather than ... an obstacle" (Norcliffe 77).

A chiaroscuro pattern of severe illness and forceful antidote therefore emerges across the Divine Songs, so that "though distresse continu for a night, / Yet joy returneth by the morning light" ("The Discourse 160-1). In "A Song shewing the Mercies of God", Collins records her pantheistic rapture as seasonal barrenness proves a temporary curse: "The Earth becomes fruitful \& plesant with flowers / That what in winter seemed dead, / There by the Sun is life discovered" (8-10). Collins' poems are, in this respect, Janusfaced: one half relives the experience of intense melancholy, whilst the other looks beyond - or rather upward - in an effort to transcend earthly sorrow by way of faith. ${ }^{49}$ The melancholic expressions of the Divine Songs are thus framed as the digressive, rather

\footnotetext{
${ }^{49} \mathrm{Cf}$. Femke Molekamp's discussion of Elizabeth Melville's religious poetry in Women and the Bible: "Affectivity is not to be denied in Melville's religious writing, as she gives a strong voice to the deep sorrow and grief that is felt in the absence of Christ ... The combination of penitence and assurance of election ultimately allows the modulation of that grief, however, so that it may be turned to passionate hope and glory" (150).
} 
than the central, aspects of Collins' poetic persona, distanced both temporally and tonally from her ideal subjectivity as a woman devoted to God.

At junctures, Collins further objectifies melancholic experience by shifting into the didactic register that marks the following passage from "Another Song exciting to spirituall mirth":

He that is melancolly,

Detesting all Delight,

His Wits by sottish Folly

Are ruinated quite

Sparks of joy

Fly away,

Floods of Cares arise,

And all delightfull Mocions

In the conception dies.

$(40-52)$

Clearly, Collins' use of the male pronoun is a diversion of sorts, intended to locate the poetic speaker's (female) voice in a moralising realm above "He that is melancolly". Given Collins' intimate relation of emotional turmoil in this poem and others, though, it is plausible that the male subject of "Another Song" is merely another of her poetic faces - a past or buried emotional self which, at the time of writing, is judged so shameful that that self must be wholly re-gendered in order to receive admission into her verse. The male melancholic is here made the scapegoat for affect which the singer of the Divine Songs is reluctant to own herself.

The "sottish Folly" which Collins denigrates is subtly, but significantly, associated with the wrong type of knowledge. ${ }^{50}$ The kind of stupidity that Collins attributes to "He that is melancolly" is the scholarly vainglory that ruins natural wit, and that extinguishes the happiness which comes from simple truths. Elsewhere in the Divine

\footnotetext{
${ }^{50}$ Jeremiah 4.22 reads: "For my people is foolish, they have not known me; they are sottish children, and they have none understanding: they are wise to do evil, but to do good they have no knowledge".
} 
Songs, Collins associates scholarly learning with profanity in this manner. The following aphorism from "A Song demonstrating The vanities of Earthly things" could be tailormade for a genial melancholic like Hamlet or Robert Burton: "Learning is sure an excellent thing ... Yet it is not from vanity free, / For many great Scholars prophane often be" (21-4). Such criticisms, which effectively denounce Renaissance culture's yoking of intellectual exceptionalism and melancholy, undermine the Burtonic notion of intelligence.

It is important to note, however, that Collins is not opposed to learning in principle. She condemns with equal severity the sealing of the mind against all knowledge. "Where the mind's obscure and dark", she counsels, "There is no vertu resident, / Of goodnesse there remains no spark" ("Another Song" ["Having Restrained Discontent"] 19-21). Rather, it is the Anatomy's showy demonstration of intelligence the kind that tabulates others' knowledge in the hopes of distinguishing oneself for vanity's sake - that Collins opposes. For Collins, all worldly authorities are fallen, and hence their words can impart no illuminating truth. It follows that in Collins' alternative conception, intelligence is defined as receptivity to holy authority, and to holy authority only. This principle receives its fullest expression in "A Song expressing their happinesse who have Communion with Christ", in which melancholy proves the sowing-ground for divine communion. "My mind, she writes, "findes out a shade / Which fruitless Trees, false fear, despair / And melancolly made" (2-4):

Whereof my judgment being certifide My mind from thence did move,

For her conception so to provide, That it might not abortive prove,

Which fruit to signifie It was conceaved by

Most true intelligence Of this sweet truth divine

Who formed thee is thine, Whence sprang this inference ... 
Playing on both senses of "intelligence" - of secrets conveyed, and of intellectual aptitude - Collins suggests that the thinker open to divine communion gains access to far greater truths than those who, because terrestrially bound to the study of geometry, geography, astronomy, or divinity, "mis of heaven and heavenly blis" ("A Song demonstrating The vanities of Earthly Things" 25-28).

But whilst Collins' verse stages a retreat from reality in its resistance to external (textual) influence of the kind that characterizes Burton's and Shakespeare's melancholic discourse, her poetic discourse also wholeheartedly pulls God and His Word into its frame of reference. Beyond figuring as the dialogician on the other side of communion (as in “A Song expressing their happinesse"), God's voice also features in Collins' songs in a more material fashion. For Collins' verse is replete with biblical allusion. Mary Eleanor Norcliffe astutely notes of Divine Songs that "the flow of biblical quotation and paraphrase is constant" (93), and as the appendix to this thesis demonstrates, Sidney Gottlieb's gallery of glosses in the most recent edition of Collins' poetry reads as a veritable catalogue of the Testaments.

Collins' sense of the word Meditacion, as she uses it in her collection's title, is "both likened to 'study' and yet implicitly contrasted with it" (Wilcox 184). If Collins is indeed a student of sorts, hers is both a similar and a very different kind of scholarship to Burton's. Just as scholarship was for melancholic men like Burton a form of selffashioning, scripture was for early modern women a means to compiling and expressing an authoritative - and just as importantly, a culturally-authorized - subjectivity. Femke Molekamp has demonstrated how "The private meditation of early modern women was ... almost always textually based, sometimes using printed meditations, often on quotidian subjects with biblical references supplied, but most frequently on passages of 
scripture, particularly psalms" (193). Imitating this practice of private, textual meditation in her verse Meditacions, Collins draws exclusively from the Bible, thereby side-stepping the pejoratively cultural (the equivalent of Shakespeare's maidenly ditties, or Burton's intellectual extractions), and assembling a poetic discourse which travels directly to the highest source of them all, endorsing only one voice beyond her own: God's.

In the sense that her words come from elsewhere, then, Collins' discourse might be called significantly heteroglossic. Because of the absolute nature of her sole source, however, she retains a key agency in her acts of textual grafting, able to force all voices to coalesce within the interiorized structure of what Bakhtin would refer to as her "poetic consciousness" (286). Burton does not achieve this feat: his Anatomy is too mosaic a document, his idiosyncratic voice made undetectable within the fray. So, too, does the polyphonous nature of Ophelia's and the Jailer's Daughter's discourse discount the possibility of a single, unifying narrative or consciousness. But Collins, because she operates according to the reformed principle that "the Bible is a collection of constellated writings that speak of one story" (Brownlee 1), and according to "the Protestant injunction to observe sola scriptura as the centre of authority for faith, doctrine, and devotional practice" (Molekamp 5), is able to sustain in her paraphrastic verse a through-line of faith which lends a stability to her utterances.

Rather than quotations and outsourced voices moving, in centripetal motion, towards the Divine Songs' speaker to transpose consciousness, Collins' model of citational correspondence sees any references made move centrifugally outwards from their utterer, permeated through by her originating subjectivity. ${ }^{51}$ Bakhtin puts it more simply: the poet applies meaning "without quotation marks", so that each effusion

\footnotetext{
${ }^{51}$ In addressing these different models of correspondence, I draw on Jerome Mazzaro's vocabulary in "Madness and Memory: Shakespeare's Hamlet and King Lear", Comparative Drama, vol. 19, no. 2, 1985, pp. 97-116 (see p. 106).
} 
becomes a "pure and direct expression of his (sic) own intention" (Bakhtin 256). Divine inspiration may come from God and the Bible, but the devotional poet still finds in the relative solipsism of confession an enticing opportunity for self-authorship. Norcliffe summarises this dependence-independence relationship perfectly: “Collins claims power through her role as God's instrument, a mouthpiece for divine thoughts and words. But she adopts this role without losing power as an individual voice/poet/author/psalmist with important things to say of her own" (98).

\section{Conclusion}

As the given extracts of Collins' poetry may illustrate, however, the "important things" she has to say are seldom melancholic in content. It is important, therefore, not to accept naively Collins' pronouncement of her writerly forthrightness and humility as a shortcut to understanding her melancholy. As Bronwen Price has remarked, there is a selfconsciousness to Collins' establishment of her authorial ethos which complicates attempts to elevate her confessional verse on the count of sincerity ("Image of her Mind" 161-3). ${ }^{52}$ This, Wilcox claims, is the great paradox of the seventeenth-century devotional act. "The language may well be simple, and the mood is intimate", Wilcox muses, "but ... these are not straightforwardly personal poems" (173). Just because Collins demonstrates a univocal control over her own poetic discourse, then, does not mean that her melancholic subjectivity is made transparent for the reading. Collins participates in a confessional literature "ordered according to the infinite task of extracting from the depths of oneself, in between the words, a truth which the very form of confession holds out like a

\footnotetext{
52 The ascription of sincerity or authenticity to women's writing simply because there is a congruence between the gender of the writer and the work produced is becoming increasingly outmoded in the wider field of feminist literary studies. "It is no longer possible", wrote Rita Felski in 1989, "to justify the value of feminist literature by simply asserting that it offers an authentic representation of the female subject" (51).
} 
shimmering mirage" (Foucault History of Sexuality 59) - but the particular affective truth I want to get to, she withholds.

Indeed, in her refusal to manifest discursively the melancholy selfhood she admits to having within, Collins draws closer to the enigma of Hamlet than any of the other female melancholics considered within this thesis. There may be gendered reasons, however, for her emotional reticence. "Beware", Helene Cixous advises the next generation of women writers in "The Laugh of the Medusa" (1976), "of diagnoses that would reduce your generative powers" (892). Just so, Collins confesses in the midseventeenth century a melancholy that is neither amenable to classification in gender terms, nor evocative of pity. Recovering in her verse the substitutory lost object of confessional writing, Collins effectively writes through her woe. ${ }^{53}$ Rather than dispersing her subjectivity across a free-associating and other-referencing stream of words, she rallies her rational resources to use words to another purpose - not for complaint, but for self-consolation. Hyper-aware of lapsing into a feminized complaint which would confirm "anxieties about the disorderly potential of the female body" and the "destructive perturbations of excessive passion" (Molekamp 120), Collins doctors her melancholy in a manner which, ultimately, results in the same erasure of that affective subjectivity as we see in Hamlet and The Two Noble Kinsmen.

It is this final inscrutability which comes to replace Burton's earlier diagnosis of women's discursive un-reason in the Anatomy. If abstruseness is the new order of the day, then Jacques Ferrand's comparison of lovesick women to a distilling apparatus might constitute a fitting conclusion to the discussion of female melancholy from within and without:

\footnotetext{
${ }^{53}$ Cf. Stanley Stewart: "For Collins, writing is like homeopathic medicine" (33).
} 
They may, not unjustly, be compared unto an Alembick, that stands quietly upon its frame, without any shew of Fire at all under it: but if you lift it up, and look under it; and could but as easily see into the hearts of these Women; you shall there discover an equall Heat in both. (217)

Ferrand's analogy suggests that the heart of female melancholy remains a thing found only in the realm of metaphor or hypothesis. Certainly in Collins and Shakespeare, the modern reader's insatiable desire to interpret - to get to the bottom of what is before us is obstructed by a female-voiced discourse which refuses to "shew" the substantial melancholy that we were so hoping to find. The texts, we might say, win. It is notable that even Collins, writing in a confessional form which we would expect to transmit the truth of innermost selfhood, steers clear of personal, emotional expression in her poetry. Her devotional discourse seems at first markedly opposed to the bawdy complaint of Ophelia and the Jailer's Daughter, and yet an untappable silence belies both, a heart that does not speak. It remains for us to judge whether the female melancholic's silence might in fact say as much as her words. 


\section{The Monuments Melancholy Makes}

They may, not unjustly, be compared unto an Alembick, that stands quietly upon its frame, without any shew of Fire at all under it: but if you lift it up, and look under it; and could but as easily see into the hearts of these Women; you shall there discover an equall Heat in both.

- Jacques Ferrand, Erotomania

As a coda to the previous chapter, Ferrand's metaphor served as an apt figure for the missing substantives which may or may not underlie the female melancholic's floating discourse. As an epigraph to this chapter, the analogy is intriguing instead for Ferrand's choice of the alembic as his object of comparison. An alembic is a distilling contraption which is used, through various processes of refinement or transmutation, to trigger molecular change in metal and mineral substances. Lit underneath - as Ferrand describes - with an expediting fire, and commonly closed at the opening with a hermetic seal, the alembic was a vital apparatus in the early modern alchemist's laboratory. Ferrand's picturing of the alembic as a nucleus for the "Heat" of erotomania thus introduces an intriguing link between the physiological disorder of melancholy, and the proto-scientific practice of alchemy.

Ferrand's metaphor functions as metaphors typically do. In it, the material object (the alembic, in this case) is successfully carried over to invest the abstract subject (the silent nature of female erotic melancholy) with concrete presence. What I want to explore in this chapter is a different mode of metaphorical transference altogether: one that sees a notably material metamorphosis, the alchemical or humoural change of state, applied to 
a female body that is bound to an equivalently-material experience of grief. I have already mentioned that female grief was in the Renaissance typically traced to clearly-demarcated objects or conditions, and often - as in the Anatomy's example - to vitiating effect. My own effort to revise the prevailing conceptualisation of early modern female melancholy, however, need not spell the throwing out of object-based definitions with the bathwater. Though Burton's identification of a lack of sex as the primary cause of women's melancholy may be safely jettisoned, it is true that there existed in this period certain repeating conditions of life - many originating in the sexed body - which made early modern women's experience of melancholy perhaps materially quantifiable than that of homo melancholicus.

According to Freud's object-based distinction between mourning (object presence) and melancholia (object absence), the greater aetiological concreteness of the sadness suffered by the female speakers that feature in this chapter would be immediately disqualified from diagnosis as melancholy. In the Renaissance, however, this distinction did not hold the same force, and many poets and dramatists of the period can be seen to assign melancholy to speakers whose affect evidently does attach to clearly-defined lost objects. The argument I put forward in this chapter thus pushes against Freudian melancholy's affinity with the immaterial or abstracted lost object in order to explore how, in seventeenth-century literature, the concrete can in fact prove a catalyst to transforming women's ritual mourning-work into a form of melancholy.

The argument that follows is one that depends on correspondence. As Foucault and others have argued, the Renaissance's similitude-based episteme supported the analogising of seemingly-disparate ideological systems. Under this way of knowing, "To search for a meaning is to bring to light a resemblance", and "To search for the law governing signs is to discover the things that are alike" (Foucault Order of Things 33). 
Accordingly, this chapter brings together three different strands of Renaissance thought and culture: the funeral monument, the conceit of Ovidian metamorphosis, and the art (or science) of alchemy. All three are bound by the same ontological narrative of liminality and change, and all three coalesce to make of the material a lasting artifact. I first discuss the use of the monumentalisation trope in Webster's Duchess of Malfi, Shakespeare's The Winter's Tale, and Milton's Comus, before reading Hester Pulter's baroque poetry of loss for its investment of basic marmorisation with alchemical significance. ${ }^{54}$ In doing so, I hope to demonstrate early modern female melancholy as - in this sense at least - very much a matter of matter.

\section{Monuments, mourning, alchemy}

Monuments are inherently melancholy things. Whether funereal sepulchre, commemorative slab, or heraldic statue, these artifacts articulate exactly the condition of death-in-life - or perhaps of life-in-death - that so burdens the humoural melancholic. For if the monument was in the early modern period erected as a firm reminder of mankind's terminal condition, then it served at the same time to limn and perpetuate life. Take Westminster Abbey, set aside since the Middle Ages as the final resting place for England's Kings and Queens. As any photograph testifies, the effigy-topped tombs which populate the Abbey serve a dual purpose. The first is to depict the noble subject in reclining posture, as ready to ascend to heaven; the second, to record that subject's mortal glory for posterity. Elizabeth I's monument, in particular, can be seen to wear little respect for either humility or expense, its sheer scale, lavish ornamentation, and verisimilar construction rendering the remains within the vault still more perishable by contrast.

\footnotetext{
${ }^{54}$ I adopt the term "marmorisation" from Patricia Phillippy's use of it in her recent article "“Chain'd up in Alabaster': Awakening Remembrance in The Winter's Tale and Comus", which also treats of Hermione's and the Lady's respective turns to stone.
} 
Carved into pale marble, Elizabeth I is made permanent in likeness. Inside her tomb, she continues to degrade to dust, as dis-identified as Alexander made into a bunghole. ${ }^{55}$

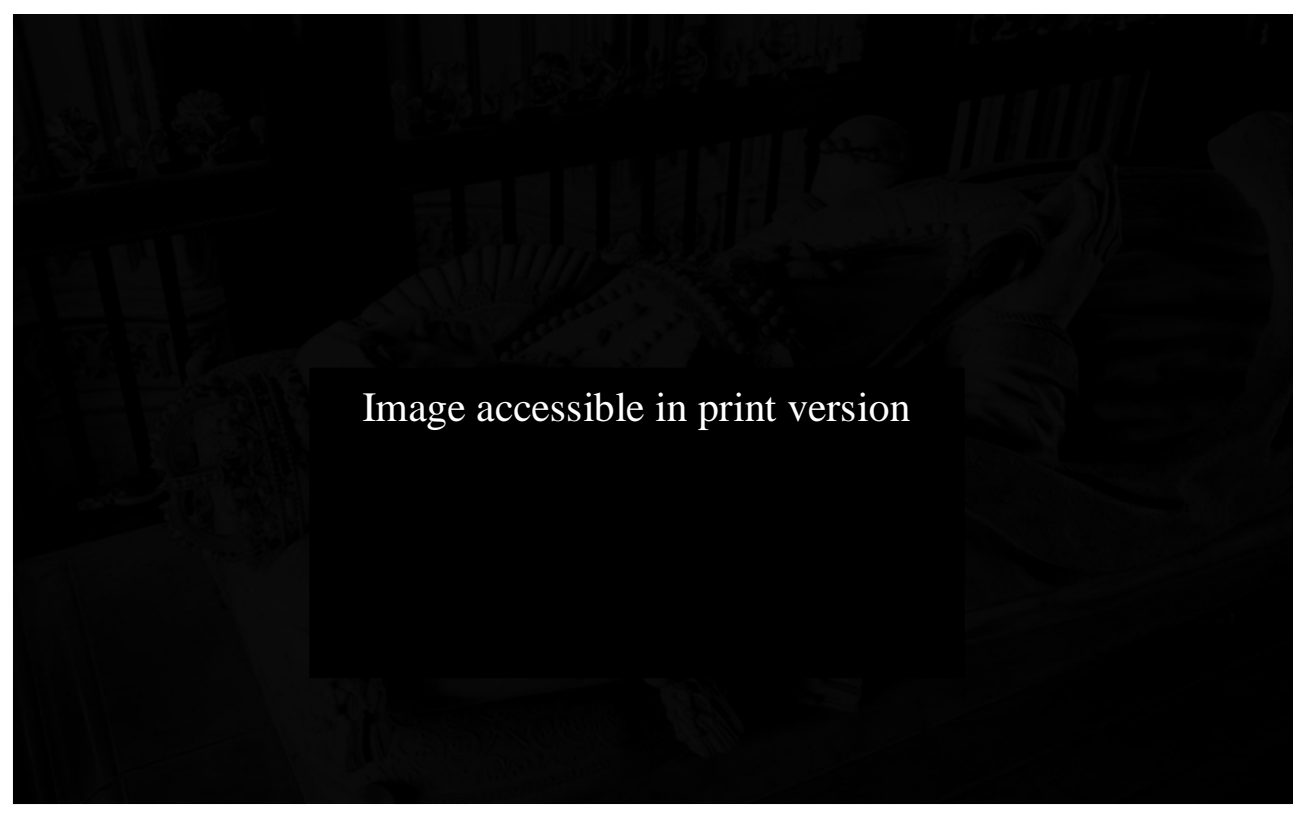

Figure 3: The effigy of Elizabeth I, lying in Westminster Abbey.

The liminal status of the monument is matched by the morbid contemplations of the Renaissance melancholic. Consider Donne's reflection on his depressive fever in a 1631 letter: "I am afraid that death will play with me so long as he will forget to kill me, and suffer me to live, in a languishing and useless age, a life that is rather a forgetting that I am dead, than of living" (Letters 120). There is no poet better than Donne to exemplify the soteriological confusion effected by, on the one hand, a solipsistic desire to monumentalize the self, and on the other, a Christian admission of the necessity of bodily dissolution for purposes of life eternal. Donne famously posed for his own funeral effigy when he realized he was nearing death, wrapping a winding-sheet around himself, and according to Izaac Walton's The Life of Dr John Donne (1640) - placing his hands “as dead bodies are usually fitted, to be shrowded and put into their coffin, or grave" (52).

55 "To what base uses we must return, Horatio. Why may not imagination trace the noble dust of Alexander till 'a find it stopping a bunghole?" (Ham. 5.1.183-5). 
This mode of self-marmorisation, which seems at least partly directed toward the incitement of "public sorrow" (55) during and beyond the funeral, is at odds with what Walton reports as Donne's concomitant longing for "the day of his dissolution" (51), and with the principles of Ars moriendi more generally. ${ }^{56}$ Why imprint the memory of the self on earth, if (as the Book of Common Prayer states) earth is to earth, and dust to dust? I will return to the subversive, the iconographic, nature of the monument later, but for now it is worth pondering the exchange that occurs at the material level when it comes to preserving life until Judgment Day. Donne's protracted end exemplifies this exchange: the embodied man is dissolved to ashes, and until he is raised again, his verisimilar monument acts as a substitute, a speaking promise of resurrection. As Walton writes at the end of his biography, “[Donne's] body, which once was a Temple of the Holy Ghost ... is now become a small quantity of Christian dust" - "But", Walton forebodes in the last line, "I shall see it re-animated" (57).

Perhaps paradoxically, stone held by the seventeenth century firm associations with human sentience. Renaissance humanism had done as much as the Bible to posit this vitality of stone. ${ }^{57}$ Ovid's Metamorphoses, it is well known, was a crucial text in the humanist syllabus in England from the mid-sixteenth century onwards, the poem's myriad

\footnotetext{
56 "For a Protestant culture that had severed its commemorative connections to the dead, monuments, both statuary and poetic, had become charged symbols that represented the precarious enterprise of attempting to secure a posthumous existence. Rather than seeking to commemorate a life well lived, post-Reformation statuary representations seemed designed to allow their subjects to straddle the border between this world and the next" (Chalk 110).

${ }^{57}$ Humanism would have introduced early moderns to such creation stories as that found within Ovid's Metamorphoses (8AD), which precedes the Bible in locating the birth of humanity in a change of state:
}

The stones (who would believe the thing, but that the time of old Reports it for a steadfast truth?), of nature tough and hard, Began to wax both soft and smooth and shortly afterward To win therewith a better shape; and, as they did increase, A milder nature in them grew and rudeness gan to cease. (1.476-80) 
tales of transition and change widely disseminated through vernacular culture following Arthur Golding's 1567 translation. The Metamorphoses supplied abundant material for humanist poets interested in the topos of female grief, and few myths were more enthusiastically adopted to this elegiac end than that of Niobe. As Lynn Enterline has chronicled, the tale of Niobe was a popular myth in the grammar-school curriculum, widely read and imitated by male students in Shakespeare's generation and beyond as a model of female complaint. ${ }^{58}$ From Spenser's Faerie Queene to Shakespeare's Hamlet, Niobe was a favourite classical citation for poets interested in representing women's grief. One of Donne's epigraphs attests to this trend:

"Niobe"

By children's births and death I am become

So dry that I am now made mine own tombe. (7)

The collective death to which Donne refers is the massacring of Niobe's fourteen children, the "Niobids", as punishment for their mother's hubris. The expanded version of the Niobe tale as it appears in Golding's translation of the Metamorphoses will serve to contextualise Donne's epigraph further. "Down [Niobe] sat", Ovid records, picking up as the last of Niobe's daughters is killed -

Bereft of her children quite and drawing to her fate Among her daughters and sons and husband newly dead. Her cheeks waxed hard; the air could stir no hair upon her head; The colour of her face was dim and clearly void of blood; And sadly under open lids unmoved stood. In all her body was no life. For even her very tongue And palate of her mouth was hard, and each to other clung. Her pulses ceased for to beat; her neck did cease to bow, Her arms to stir, her feet to go. All power forwent as now, And into stone her very womb and bowels also bind.

But yet she wept and, being hoist by force of whirling wind, Was carried into Phrygie. There upon a mountain's top She weepeth still in stone; from stone the dreary tears do drop. (6.382-395)

\footnotetext{
${ }^{58}$ Alongside Hecuba, Niobe was a mythical woman "whose passion it was a Latin-speaking gentleman's task to imitate, feel, and convincingly move in others" (Enterline 139).
} 


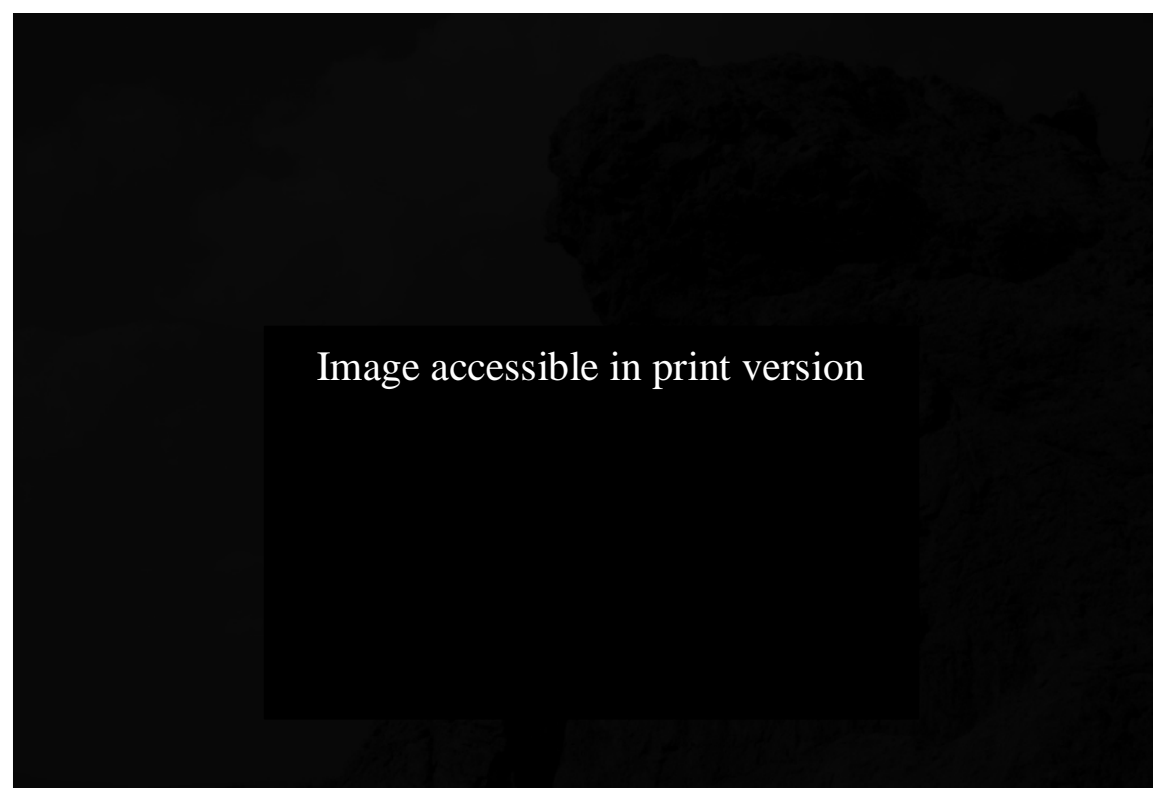

Figure 4: Atop Mount Sipylus in modern-day Turkey sits the Weeping Rock (also known, since antiquity, as Niobe's Rock).

Niobe is the classical paradigm of feminized, enspirited stone, her eternal grief emblematizing the same kind of intermediacy involved in Donne's live-posing for his funeral effigy. Like Donne's pre-humous ritual, Niobe's shedding of “dreary tears" in perpetuum is, in a way, an availing of the assault done her by the Gods. By way of marmorisation, Niobe approaches the status of her divine punishers temporally, her narrative chronology extended interminably beyond the text (and, to an extent, beyond fictionality: as Golding's translation tells us, moving smoothly from the past to the present tense, Niobe's petrified form is "still" to be found atop a mountain). Niobe suffers a condition of Sybillic life - rooted to the earth, petrified in non-movement - but, in an integral point of difference to the male melancholic's eschatological outlook (recall Donne's desire for "dissolution"), she-as-monument continues to memorialize affect in a manner that prolongs circumstantial grief to the point of subversion. Since we know that such dogged extensions of grief ran counter to early modern cultural and religious codes which looked upon women's excessive mourning with suspicion (Goodland 103), the 
literary troping of monumentalisation in the Renaissance emerges as a topic for further consideration within a thesis about female melancholy.

And so onto alchemy. The hundreds of moments of transition within the Metamorphoses are already steeped in language which borders on the alchemical. Consider Ovid's use of the Latin verb "congelat" in his tale of Niobe, his attention to the way fleshly atoms wax into solid form. ${ }^{59}$ Some 1600 years later, European alchemists would adopt a similar attitude towards the inanimate world. Beyond simply "us[ing] Ovid as a rich source of enigmatic allusion," Renaissance alchemists "also claimed that the Metamorphoses and other myths were consciously Hermetic and alchemical works" (Abraham 285). Just as Ovid claimed in the Metamorphoses to sing of "shapes transformed to bodies strange" (1.1), so were alchemists of the sixteenth and seventeenth centuries driven by a firm belief in the metamorphic potential of organic and inorganic organisms. Take the following explanation of transmutation, which as well describes the transformation of Ovid's maiden Anaxarete to marble as the alchemist's metals to minerals: "Transmutation therefore is when a thing loseth its form and is so altered that is altogether unlike to its former substance and form, but assumes another form, another essence, another colour, another vertue, another nature, or property, as if a Metall bee made glasse or stone” (Linden, “The Alchemy Reader" 177).

This definition is taken not from Ovid's poem but from the writings of sixteenthcentury alchemist Paracelsus, who with such seminal treatises as Of the Nature of Things (1537) pioneered alchemical practice in early modern Europe. Paracelsus further demonstrates his debt to antecedents like Ovid when he claims that "There is nothing

\footnotetext{
${ }^{59}$ For a discussion of the importance of this verb, see Edward Paleit, "Women's Poetry and Classical Authors: Lucy Hutchinson and the Classicization of Scipture", Early Modern Women and the Poem, ed. Susan Wiseman, Manchester University Press, 2014, pp. 21-41 (see p. 28).
} 
corporeal which does not possess a soul hidden in it" ("Cosmology", Hartmann 62). It was this hylozoistic belief in the sentience of all matter that motivated the alchemists' attempts to bring base metals to golden perfection. Through such alchemical processes as distillation, putrefaction, and calcification, followers of Paracelsus strove to attain the most apocryphal of materials: the philosopher's stone. The vogue for Paracelsianism in the later English Renaissance makes this Swiss polymath a key point of reference for writers working within, and metaphorically adding to, the popular tradition of Ovidian metamorphosis. Hester Pulter is one such writer, and in the final section of this chapter, I argue that the alchemical metaphors at work in her poetry help to draw out the defensive dimensions of the female melancholic's self-marmorisation.

\section{Melancholy sto[ne]icism in male-authored drama}

As New Materialists have insisted, "humour" was for the early moderns rarely a description of emotional temperament merely. Melancholy conjured in the Renaissance psyche images of cold and dry bodies, and of immobilized fibres. ${ }^{60}$ It is little wonder, then, that melancholy is so often depicted in literature from this era as culminating in some degree of marmorisation. Consider the corpse-like condition that Friar Lawrence anticipates his potion to effect on the body of young Juliet:

presently through all thy veins shall run A cold and drowsy humour - for no pulse Shall keep his native progress but surcease; No warmth, no breath, shall testify thou livest; The roses in thy lips and cheeks shall fade To wanny ashes; thy eyes' windows fall Like Death when he shuts up the day of life; Each part, deprived of supple government, Shall stiff and stark and cold appear, like death And in this borrowed likeness of shrunk death Thou shalt continue two-and-forty hours,

${ }^{60}$ Foucault regularly refers to the melancholic's characteristic "immobility" in Madness and Civilisation $(84,114,118,120)$. See also Saturn and Melancholy: "black bile ... can induce paralysis or torpor or depression or anxiety when it prevails in the body" (23). 
And then awake as from a pleasant sleep.

(Romeo and Juliet 4.1.95-106)

Given the strong association between melancholy and stasis in the Renaissance, it would have been immediately clear to Shakespeare's audience which of the four humours was responsible for so arresting Juliet's internal networks at the moment of her first death. Melancholy, after all, is the cousin of mortality: in all its permeating activity - running, fading, falling, shutting up, depriving, as in Friar Lawrence's soliloquy - it, too, drains the body of life. But Juliet's is not just any body. Hers is a young, fertile, female body, and at least part of the Friar's descriptive scare-mongering in response to the girl's proposition of suicide can be attributed to this factor of sex. The image of Juliet's rigid corpse lying in the Capulet tomb is made the more tragic for its picturing of her 13-yearold female body withered prematurely, at the height of its girlhood. Juliet's youthful femininity explains, too, the urgency of her character's being reawakened to shake off her "shrunk death" (4.1.93) and die in a decidedly more naturalistic fashion, body "bleeding [and] warm" (5.3.175). This second death appears to be corrective in presentation, revising the poison's de-sexing effects by restoring Juliet's body with moist and alive Galenic femininity.

Melancholy's drying and hardening influence over the female body is, in Romeo and Juliet, a mere digression from the main tragic plot. In The Duchess of Malfi, The Winter's Tale, and Comus, on the other hand, this Galenic narrative of the body is brought front and centre, each play's leading heroine turning to stone (or its abstract equivalent) for reasons inextricable from cultural anxieties surrounding women's reproductive function. In the Renaissance, the word "sad" denoted sorrow first and foremost, but it also boasted a set of highly material nuances. As a verb, "sad" meant "to make solid, firm, or stiff"; adjectivally, the term could indicate constancy of purpose or fixity of condition, as 
in valiance, the ability to resist $(O E D) .{ }^{61}$ The female dramatis personae I consider below combine both of these senses when they find themselves spurred, by male betrayal or assault, to literally or metaphorically calcify in their grief as a contrary declaration of constancy, chastity, and nobility - to achieve a state of "sadness" emotionally as well as physically. ${ }^{62}$

I start with the exceptionally corporeal heroine of John Webster's 1614 play, The Duchess of Malfi. Said to boast a look which "were able to raise one to a galliard, / That lay in a dead palsy" (1.1.190-1), Webster's widowed Duchess is quick to blush, to sweat, and to eat onstage, and she actively seduces her chosen love object, the steward Antonio, into the marriage bed. In the play's first scene, she interrogates Antonio's sexual restraint by offering to him her living form:

Sir, be confident,

What is't distracts you? This is flesh and blood, sir;

'Tis not the figure cut in alabaster

Kneels at my husband's tomb. (1.1.440-3)

Her persuasion does the trick, and as if the Duchess were not a bodily character enough, soon she is also "troubled with the mother" $(2.1 .124)$, her pregnant body discursively and visibly advertised for a central holding of the play. Judging by her refusal to be "cased up like a holy relic" (3.2.139), then, the Duchess is no champion of anatomical reticence (Maus 190). As the play's macabre plot unfolds, however, her expression of sexuality undergoes significant self-moderation, as she is hardened by external assaults into an emotional apatheia that is more than once figured in the language of humoural petrification.

\footnotetext{
${ }^{61}$ I take the first part of this definition from Douglas Trevor (The Poetics of Melancholy), p. 48.

${ }^{62}$ Michael Neill conducts a similar reading of Antony and Cleopatra in Issues of Death, understanding Cleopatra's suicide as "a continuous tableau of constancy" reminiscent of marmoreal transformation (312).
} 
If Pygmalion, Ovid's preeminent sculptor of the female form, watches his marble mate soften from stone, to wax, to finally become flesh - and highly fertile flesh, at that - then the Duchess' character trajectory wholly reverses this progress of states. ${ }^{63}$ In response to the cruel tricks orchestrated by her brother, the Duke Ferdinand, the Duchess swiftly adopts a melancholy stance that is distinguished by affective stoicism, philosophical pessimism, and an impulse to physical rigidity. ${ }^{64}$ The Duke's cruellest trick, the Tussauds-like exhibition of Antonio's and the children's ostensibly slain forms, spurs the Duchess' request that she be bound to her husband's lifeless body so that she may "freeze to death" (4.1.66). That desire denied by the guards, the Duchess sets out to realize it herself. By the time the play's duplicitous "tomb-maker" (4.2.162), Bosola, enters the execution chamber to bring the Duchess "by degrees to mortification" (4.2.164), he finds that his victim has, affectively-speaking, already absented herself. Casting her former rejection of the "figure cut in alabaster" as a self-fulfilling prophecy, the Duchess kneels in stoic fashion to receive her fatal strangulation, steeled in a melancholy livery which excises normative female softness (Neill 340-1). ${ }^{65}$

The melancholy resolve of Webster's Duchess likens her to Hermione from Shakespeare's The Winter's Tale (1610-11), who in response to her husband Leontes' hysterical accusation of adultery disappears from the play's plot only to return, sixteen years later, as a statue. Similarly to the Duchess, Hermione's status as a mother is foregrounded: she spends the early scenes of her play pregnant, and reanimates at its end

\footnotetext{
${ }^{63}$ See Ovid: "The marriage that herself had made the goddess blessed so / That, when the moon with fulsome light nine times her course had go, / This lady was delivered of a son that Paphos hight ..." (Metamorphoses 10.321-3).

${ }^{64}$ The maid Cariola says that the Duchess looks in her imprisonment like "some reverend monument / Whose ruins are even pitied" (32-3).

${ }^{65}$ Cf. Michael Neill: that "the Duchess self-consciously dresses her defiance of both rank and gender norms in the heroic rhetoric of male chivalry" (348). See also Brian Chalk: the Duchess "is a monument that refuses rather than confirms transcendence" (135).
} 
expressly to reunite with her lost daughter. Prior to her mysterious marmorisation, Hermione airs the following speech to the man who has betrayed her:

I am not prone to weeping as our sex

Commonly are, the want of which vain dew

Perchance shall dry your pities. But I have

That honourable grief lodged here which burns

Worse than tears drown. (2.1. 109-113)

In recognising that her dryness might so dry her male audience's pity, Hermione anticipates a gendered charge against her lack of material affect. It is true, then, that neither as fully animate woman nor as pneumatic stone is Hermione a true weeping Niobe (she denies precisely the tears that define that mythological mother). But though Hermione's tears are wanting, her "honourable grief" blazes in subterraneous regions. The vague "here" that Hermione alludes to is reminiscent of the surface stoicism Ferrand perceives in the alembic which, "stand[ing] quietly upon its frame", occludes its internal fire. ${ }^{66}$ Hermione's self-marmorisation, like the Duchess' affective version, thus constitutes an almost deific act, making out of her form a lasting icon - a material object of loss - set to ignite Leontes' guilt with each fresh beholding. ${ }^{67}$

Seeing his wife's statue for the first time, Leontes notes with angst that the Hermione he knew "was not so much wrinkled", "nothing / So aged as this seems" (5.3.28-9). Whether or not Hermione has undergone literal petrification, this detail tells us that her body has continued to age in situ. Leontes' preoccupation with the relative sexlessness that the statue connotes (notice his use of the neutral pronoun "this") reveals

\footnotetext{
${ }^{66}$ Stoical resonances are even nearer due to the etymological proximity of "Hermione" to hiermarmene, the classical doctrine of fate and destiny, cause and effect. Heirmamene was a common figure in the Hellenistic philosophical tradition of Stoicism, symbolizing the cosmological logos and providence to which the Stoic deferred. For more, see Samuel Sambursky, Physics of the Stoics, Princeton University Press, 1987, p. 57.

67 As Jennifer C. Vaught observes, the presumed death of Hermione leads to a reversal of conventional mourning roles in which Leontes takes up the female-coded ritual of shedding tears beside the grave (168).
} 
a libidinal anxiety regarding his wronged wife's biological "clock", which has seemingly continued to tick even as, or if, Hermione's truly vital organs have - like Niobe's womb and bowels - been irreparably bound by stone. ${ }^{68}$ As Patricia Phillippy observes, "Hermione's wrinkles register the passage of time that is likely to preclude the possibility of reproduction" (“'Chain'd up in Alabaster"” 208). Hermione hence emerges from her hibernation with a body marked by the tria prima properties of Galenic female melancholy: coldness, dryness, and barrenness. ${ }^{69}$ Supporting this interpretation are the claims of early modern authorities like Johann Weyer, Reginald Scot, and Robert Burton, who attribute in many cases women's irrational or demonic melancholy to a lack of menses, barrenness, or self-determined abstinence. ${ }^{70}$

The vital difference, though, is that the Duchess and Hermione are invested in their melancholic hardening not with irrationality or demonism but with notions of defiance and stoic nobility, as if their rejection of softness were an effort to shed the biological exigencies of the sex responsible for attracting such patriarchal assaults. This same form of obstructive metamorphosis features in Milton's Comus (1634). In Milton's masque, metaphysical and literal principles of fixity coalesce in the figure of the Lady, the young maiden who, becoming lost in a Bacchanalian forest, is trapped into a "marble venomed" (915) and "glutinous" (916) chair by the titular Comus. One would expect such

\footnotetext{
${ }^{68}$ For more on Renaissance women's biological clocks, see Amy Boesky, "Giving Time to Women: the Eternizing Project in Early Modern England", This Double Voice, ed. Danielle Clarke and Elizabeth Clarke (Palgrave, 2000), pp. 123-141.

${ }^{69} \mathrm{Cf}$. Hildegard of Bingen, writing in the $12^{\text {th }}$ century: "During the monthly menses [women] lose much blood, and they are infertile because they have a weak, fragile womb. For that reason, they can neither receive, retain, nor warm the male seed. For that reason they are more healthy, more powerful, and happier without a mate than with one because they become sick from relations with a husband" (Radden Nature of Melancholy 86).

${ }^{70}$ See The Anatomy of Melancholy: "The causes are assigned out of Hippocrates, Cleopatra, Moschion, and those old Gynaeciorum Scriptores, of this feral malady, in more ancient maids, widows, and barren Women ... offended with those vitious vapours which come from menstruous blood" (Burton 1:414). See also Reginald Scot's The Discoverie of Witchcraft (1584): women are "monthlie filled full of superfluous humors, and with them the melancholike blood boileth" (qtd. in Neely Distracted Subjects 80, footnote 16).
} 
an enchantment to signal great danger. With her "hidden strength" of virtue (414), however, the Lady is even prior to her bodily petrification a paradigm of firmness. It is this continuity of resolve which sets her apart from Webster's Duchess and Shakespeare's Hermione, female characters already involved, to their respective misfortunes, in the binding cycle of marriage and childbirth.

When the carnal Comus immanacles the Lady in her "corporal rind" (664) with intent to keep her as his sexual prisoner, he suffers the disappointment of a backfiring spell. By taking away the suppleness of flesh - the penetrability of body - he requires of the Lady in order to satiate his erotic appetite, Comus effectively gives his female captive a power to resist his penetrations that her former bodily softness made insupportable. ${ }^{71}$ Comus himself soon realizes that, by "chain[ing] up [the Lady's] nerves in alabaster" (659), he has only forged a greater communion between the Lady's interior stoicism and her material state. ${ }^{72}$ Most obtusely of all, he has failed to freeze her tongue, which so persuasively preaches "the sage / And serious doctrine of virginity" (785-6) that the enchanter himself becomes increasingly unsettled. First excusing (and simultaneously diagnosing) the Lady's moral talk as "but the lees / And settlings of a melancholy blood" (808-9, emphasis mine), Comus then complains proper, railing in the process against the now-familiar school of Stoicism:

O foolishness of men! that lend their ears To those budge doctors of the Stoic fur, And fetch their precepts from the Cynic tub Praising the lean and sallow Abstinence ... (705-8)

He continues:

if all the world

\footnotetext{
${ }^{71}$ Given the clear backfiring of Comus' hardening enchantment, it is noteworthy that the Elder Brother, defending the Lady and her chastity earlier in the piece, makes the following allusion to Medusa: "What was that snaky-headed Gorgon shield / That wise Minerva wore, unconquered virgin, / Wherewith she freezed her foes to congealed stone?" (446-8).

${ }^{72}$ The Elder Brother asserts that the young maid who possesses virtue "is clad in complete steel" (420).
} 
Should in a pet of temperance feed on pulse,

Drink the clear stream, and nothing wear but frieze,

Th'all-giver would be unthank't, would be unprais'd,

Not half his riches known ... (719-23)

In his discourse on "Maides, Nunnes, and Widowes Melancholy", Robert Burton airs a similar grievance, though he attacks Roman Catholic rather than Hellenistic doctrine as the cause of abstinence-induced cases of erotic melancholy:

How odious and abominable are those superstitious and rash vowes of Popish Monasteries, so to binde and enforce men and women to vowe virginity, to lead a single life against the lawes of nature, opposite to religion, pollicy, and humanity, so to starve, to offer violence, to suppresse the vigor of youth, by rigorous statutes, severe lawes, vaine perswasions, to debarre them of that, to which by their innate temperature they are so furiously inclined, urgently carried, \& sometimes precipitated, even irresistibly led, to the prejudice of their souls health, and good estate of body and minde. (1:417)

In both, our patriarchal ambassadors frame virginity - the extreme, petrified version of culturally-recommended female virtue - as markedly unnatural, as opposed to the laws of Nature and so, in turn, to the intention of God for (wo)man.

Milton seems to have concurred with these diatribes concerning female sexuality enough to append to his masque a restorative resolution that mimics Shakespeare's reenlivening of Juliet. In Comus, the responsibility for reversing the Lady's entrapment is given to the nymph Sabrina, who frees the Lady with the touch of hands "moist and cold" (917). Sabrina hereby reinfuses the maiden's hardened form with the dual qualities of Galenic femininity. Galvanizing this healing measure is the suspicion that the Lady has lost some essential sex in the process of a petrification which, by removing her person from the dangerous world of male imprisonment and rape in a bodily sense, perhaps frees 
her spirit more than has been previously concluded. After all, the mind can amble freely even when the limbs cannot. ${ }^{73}$

Comus' figuring of chastity as an inflexible relic is not atypical by Renaissance standards. Poets and dramatists of the early seventeenth century commonly pictured female virtue in metal or mineral terms. ${ }^{74}$ To shift attention back to the Duchess of Malfi for a moment, consider the happily-husbanded Antonio's warning to maid Cariola, who has just expressed her intention not to marry:

We read how Daphne, for her peevish flight,

Became a fruitless bay tree, Syrinx turned

To the pale empty reed, Anaxarete

Was frozen into marble; whereas those

Which married, or proved kind unto their friends

Were, by a gracious influence, transshaped

Into the olive, pomegranate, mulberry:

Became flowers, precious stones, or eminent stars. $(3.2 .25-32)^{75}$

In this, Antonio carefully sets out a hierarchy of Ovidian bodies which prioritises the fertile or the precious (fruits, flowers, cosmic bodies) over the stagnant and unblushed (in a word, "marble"). Female frigidity is here made synonymous with androgyny and a lack of vitality, with a purification that goes a step too far - which does not cease until the female's insurance of her own virginity verges into prudishness, excising also her erotic “Heat” (Ferrand 217) and seed. What Webster's Duchess, Shakespeare's Hermione, and

\footnotetext{
${ }^{73}$ Patricia Phillippy describes the Lady's fixed state in a similar phrase: "While her 'corporal rinde' is 'immanacled', the 'freedome of [her] minde' remains her own" ("“Chain'd up the Alabaster" 192).

${ }^{74}$ Shakespeare is especially fond of this kind of humoural-cum-alchemical imagery: in Measure for Measure, for instance, nunnery-intending Isabella is said to be "of prone and speechless dialect" (1.2.171), her prudence rendering her "too cold" (2.2.58) for Lucio's forthright tongue. In Coriolanus, Valeria is rhapsodized as "The moon of Rome, chaste as the icicle / That's curdied by the frost from purest snow / And hangs on Dian's temple" (5.3.65-67). One must not forget, either, the all-too-easily-forgotten Rosaline in Romeo and Juliet, denigrated by the play's male characters as "pale" and "hard-hearted" (Q1 2.3.4) for her resistance to Romeo's suit.

${ }^{75} \mathrm{Cf}$. Theseus to Hermia in A Midsummer Night's Dream: "earthlier happy is the rose distilled / Than that which, withering on the virgin thorn, / Grows, lives, and dies in single blessedness" (1.1.74-78).
} 
Milton's Lady demonstrate in their common hardening, though, is not the straightforward loss of femininity that Antonio details, but the attainment of a kind of female vertu.

\section{Alchemical marmorisation in Pulter}

Webster, Shakespeare, and Milton figure the female character's turn to stone in a manner that implies a movement from the shadow of impurity, to the marble-light state of sto[ne]icism. The progress of hues involved in this marmorisation mimics the alchemical opus, in which base materials move from a state of primordial Chaos (known as nigredo, or darkening) through to the third - but not the last - stage of albedo (whitening). In the seventeenth century, the latter stage corresponded neatly to ideas of female virtue, as albedo brought with it ideas of purification and honour, and nigredo the opposite. Virtue, in albification, becomes indestructible; hence, early modern alchemist George Starkey claimed that fellow "chymists" coveted the end-product of such whitening as "their Swan, their Dove, their white Stone of Paradise, their white Gold, their Alabaster". ${ }^{76}$ Another proof of the correspondence between sexual and material purity in Renaissance thinking rests in the common invocation of the chaste goddess Diana as a symbol of albification in alchemical discourse. "In alchemical symbolism", accounts Lyndy Abraham, "Diana is associated with the cold, white, moist feminine nature ... [S]he is closely associated with the moon and silver (Luna) and also symbolizes the 'white stage' of the opus" (Marvell and Alchemy 256). Further clarifying the link between stone and these symbols, Abraham relates that "The alchemists also associated precious, white substances such as crystal, marble, and alabaster with the stone (or elixir) at the white stage" (Marvell and Alchemy 280).

\footnotetext{
${ }^{76}$ As quoted in Abraham, A Dictionary of Alchemical Imagery, p. 5 (emphasis mine).
} 
Carl Jung, whose Psychology and Alchemy played a key role in piquing scholarly interest in alchemy through the mid-twentieth century, pairs the nigredo stage with negative states of affect, including melancholy. "[T]he nigredo, the first stage of the work," posits Jung, "was felt as 'melancholia' in alchemy and corresponds to the encounter with the shadow in psychology" (36). The movement I am proposing, however, qualifies Jung's schema slightly. In marmorisation, the female melancholic moves out of nigredo and into whiteness, but still retaining the melancholia associated with the chaotic first stage of matter. Even as the female melancholic rejects the physical burden of reproductive biology by becoming purified stone, she retains the psychological dross of melancholy. Indeed, the latter can actually be understood to catalyse the former, melancholy's chilling and drying influence as effective an accelerant for hardening the body as any Hermes seal. Only by retaining the melancholy stance typically associated with the disorder of nigredo can the female melancholic rid herself of the bodily constraints of her gender, whilst whitening and freezing the affective experience of feminized melancholy.

The male dramatists heretofore discussed follow the Ovidian (and more specifically, the Niobic) model of metamorphosis to describe their female melancholics' turns to stone. The poetry of Hester Pulter, however, makes the alchemical dimensions of this marmorisation explicit, further illustrating the nexus between melancholy, minerals, and female mourning. Pulter's manuscript poems (composed c. 1647-1660) include a rich selection of verse complaints, many of which are explicitly melancholic in content. She even goes so far as to claim Saturn, the melancholy planet, as her birth star. ${ }^{77}$ But Saturn is for Pulter not merely a badge of intellectual and creative talent. The planet also emerges as an emblem of the notably material losses which were as responsible for Pulter's

\footnotetext{
${ }^{77}$ See Pulter's Poem 45, line 45.
} 
sustained melancholy as any natural disposition to sadness. Because as Alice Eardley notes, Saturn was also associated in early modern cosmology with the death of children - a form of loss with which Pulter, who lived to see thirteen of her fifteen sons and daughters die, was well-acquainted. ${ }^{78}$ Despite Pulter's constant attempts to capitalize on the prophetic and philosophical endowments of melancholic disorder, therefore, her transcendent (and often cosmic) reflections offer only a temporary recourse. Melancholy is rooted always in the female body, that vessel of woe, and so to the female body Pulter's poetic speaker must always return. ${ }^{79}$ This accounts for the prevalence of Ovidian and especially alchemical metaphors throughout Pulter's poetry.

Pulter's textual alchemy has been the subject of several studies in recent years, as has early modern women's practice of alchemy more generally. ${ }^{80}$ That women engaged in alchemical practice more widely than was previously thought is not an entirely unprecedented finding. Women's work in the home required of them a working knowledge of alchemical processes for the creation of everything from edible preserves to cosmetics and curative balsams, making alchemical craft little more than "an extension of women's accepted house-keeping duties and medical roles" (Bayer 380). ${ }^{81}$ For this reason, women's engagement with alchemy during the seventeenth century was a practice unrestricted by class, and the pool of known practitioners spans servants like Hannah Wolley to women as courtly as Queen Henrietta Maria. Nevertheless, wealthier women

\footnotetext{
${ }^{78}$ See Eardley's article, “'Saturn (whose aspects soe sads my soule)': Lady Hester Pulter's feminine melancholic genius", New Ways of Looking at Old Texts, IV: Papers of the Renaissance English Text Society, 2002-2006, ed. Michael Denbo (ACMRS, 2008), pp. 239254.

${ }^{79}$ Cf. Karen Britland: despite the material changes which see Pulter's speaking body purify and refine into another state, "the poet's speaking persona remains stubbornly present" (21). ${ }^{80}$ See Bayer, "From Kitchen Hearth to Learned Paracelsianism"; Archer, "A 'Perfect Circle??”; and Sarah Hutton, "Hester Pulter (c.1596-1678): A Woman Poet and the New Astronomy", Etudes Epistemes, vol. 14, no. 1, 2008, pp. 77-87.

${ }^{81}$ See also Wendy's Wall's chapter, "Temporalities: Preservation, Seasoning, and Memorialization", Recipes for Thought: Knowledge and Taste in the Early Modern English Kitchen (University of Pennsylvania Press, 2015), pp. 167-208.
} 
were able to extend their learning under the guidance of professional chemists and in the privacy of their own laboratories (Bayer 367-9).

Whether or not Hester Pulter enjoyed access to her own laboratory, her mastery of alchemy's technical lexicon is exceptional, even before taking gender into account. Out of the poems collected in Pulter's manuscript, "The Circle" is often touted as the leading expression of its author's expertise in this area of early modern science. Pulter's Emblem 40, however, offers in my opinion a denser-still exhibition of alchemical knowledge. I include the poem in full below:

View but this tulip, rose, or July flower And by a finite see an infinite power. These flowers into their chaos were retired Till human art them raised and reinspired With beating, macerating, fermentation, Calcining, chemically, with segregation. Then, lest the air these secrets should reveal, Shut up the ashes under Hermes seal. Then with a candle or a gentle fire You may reanimate at your desire These gallant plants, but if you cool the glass To their first principles they'll quickly pass. From sulphur, salt, and mercury they came; When they dissolve they turn into the same. Then seeing a wretched mortal hath the power To recreate a Virbius of a flower, Why should we fear, though sadly we retire Into our cause, our God will reinspire Our dormant dust and keep alive the same With an all-quick'ning, everlasting flame. Then though I into atoms scattered be, In indivisibles I'll trust in thee.

Then let this comfort me in my sad story;

Dust is but four degrees removed from glory. $(1-24)^{82}$

This Emblem's starting-point may be a domestic experiment (likely the distilling of oil or pigment from flowers, for cosmetic purposes),${ }^{83}$ but Pulter's sensitivity to what Ruth

\footnotetext{
${ }^{82}$ I use Alice Eardley's 2014 edition of Pulter's work, Poems, Emblems, and the Unfortunate Florinda.

${ }^{83}$ See Wendy Wall on women's practice of distillation: "Rather than an elite arcane activity, distilling was widely recognised as a craft skill undertaken by housewives, ladies, and artisans working in domestic and commercial domains" (188).
} 
Connolly calls "analogical correspondence" (2) makes of it a spiritual exercise. For Pulter, as for any Neoplatonist, flowers are the material signs of their immaterial source, and so what appears before her complete and blooming can in her schema be effortlessly re-cycled back to its primal nothingness. This "chaos" (3) of nigredo heralds, in turn, the refining of the culturally-gendered flowers back to the hermaphroditic materials of "sulphur, salt, and mercury" (13). Jayne Archer explains the alchemical significance of the first and last of these chemicals in her fine essay on Pulter's alchemy:

In alchemical symbolism, the union of mercury and sulphur is typically represented as the coming together of a white woman (sometimes a queen) and a red man (or king), who join in sexual union, are immersed in water and die, to be reborn as a single hermaphrodite body, or to give birth to an androgynous child, the philosopher's stone.(4)

Galenically speaking, sulphur was associated with fire and theorized to possess qualities of hotness and dryness, whilst Mercury was associated with water and afforded thermal qualities of coldness and moistness (Linden 14). The union of the two opposing, sexuallydifferentiated principles - also variously referred to as the red man and the white wife was a process commonly referred to as chemical bedding or coniunctio (Linden 17). In this, the alchemical end-stage, the marriage of masculine and feminine principles effectively renders the gendering of any principle obsolete, as the prima materia, like God, rejects sexed self-division. A "symbol uniting all opposites" (Jung 295), the product of coniunctio entirely removes the need to distinguish sex by material means (cosmetically, or otherwise). ${ }^{84}$

It is curious that Pulter's quest for hermaphroditic infinitude should, in Emblem 40 , spring from the creation of a cosmetic product (or products) intended to enhance those

\footnotetext{
${ }^{84}$ Jung writes of the androgyny of Mercurion: "He is the hermaphrodite that was in the beginning, that splits into the classical brother-sister duality and is reunited in the coniunctio, to appear once again at the end in the radiant form of the lumen novun, the stone. He is metallic yet liquid, matter yet spirit, cold yet fiery, poison and yet healing draught - a symbol uniting all opposites" (294-5).
} 
features which most overtly manifest humoural femininity: that is, the cheeks and the lips, those consoling ciphers of the blood which circulates the reproductive female body still. Instead of dwelling on this mortal use of her alchemical experiment's end-product, Pulter turns her attention to the abstract - to an advanced alchemical process which would refine her botanic potion further, so as to achieve a higher form rather than to serve earthly vanity. ${ }^{85}$ Even in her poem's hypothetical realm, however, Pulter's flowers have not yet refined into indivisibles. Calcination into dust is as far as they have progressed through the alembic, and "four degrees" of metamorphosis remain wedged between particlisation and their refinement to higher stuff. Even if the poetic speaker announces a preference for the immaterial, she must always return to a phenomenological reality in which femininity, in particular, is inescapably material. This stunting at the level of the physical and substantial, I argue, is an essential characteristic of the female melancholic's marmorisation. Because if "Hermes seal" typically expedites the change of states, then its marmorealic version - the mineral seal encasing the female melancholic - does quite the opposite, petrifying its host subject at the moment of acutest grief.

Pulter's poem "The Invitation into the Country" is a case in point of this subversion. The majority of Pulter's poems were composed between the 1640s and 1660s, the twenty-year period of political and social revolution - of changes of state - which saw a notable increase in the production and circulation of alchemical tracts (Archer 1). "The Invitation" is an overtly political complaint, written in response to King Charles' imprisonment in 1646. Pulter's Royalist poem is shot through with melancholy nostalgia for a Caroline yesteryear, tortuously reconstructing a Herrick-like pastoral paradise

\footnotetext{
${ }^{85}$ As Stefan Graham Christian comments of this poem, Pulter uses the domestic task of "making ... a distillate or oil of flowers" as a starting-point for a metaphysical meditation on a more advanced alchemical process (354, note 994). The name for this process was palingenesis, "whereby a plant or flower is killed and then brought back to life" (Eardley, Poems 241, footnote 356).
} 
before painting that scene over in greyscale. Ovidian nymphs and shepherds are, by "Sad metamorphosis" (74) transposed by mythical beings taken from the same classical book: Philomel appears alone, moaning to trees, and Heliadic goddesses feature, “inshrin'd in Oakes" (142) and weeping immortal tears. Nothing waterlogs the poem more, though, than the dialogue between the weeping streams. Beane, Mimram, Stort and Lea run "To tell the Thames their grieving woe" (100); the Ver, Colne, Purwell, and Ouse feature also, complaining with choler-laced sorrow of their lost Amintas (Pulter's sobriquet for Charles I).

One spring mourns with a difference. Gray’s Spring, which ran through Pulter's Hertfordshire estate of Broadfield, is the final body of water to receive mention:

Gray's Spring, too, sadly makes her moan

And with her tears turns moss to Stone

And, seeing delight with Chloris fled,

She sighed and, murmuring, hid her head

Within her womb that gave her breath,

Venting her grief below the earth. $(123-8)^{86}$

Alice Eardley, editor of the modern edition of Pulter's Poems and Emblems, footnotes at this juncture Henry Chauncy, whose Historical Antiquities of Hertfordshire contains the following reference to such a spring: "There are some petrifying Springs in the Grounds of Broadfield and in the Parish of Clothall, which crust things that are laid in them, without Penetration" (Chauncy 12). In Pulter's poem, Gray's spring takes on the role of the mineralizing agent: rather than hermetically sealing the self, it throws its hermetic seal unto alien objects or subjects, turning the Other from living to dead. The action of the spring is to marmorise animate nature - and not just any nature, but that scenery which

\footnotetext{
${ }^{86}$ A comparable stream features in the Metamorphoses, ruthlessness foregrounded:

The Cicones have a certeine streame which, being drunk, doth bring Men's bowels into marble hard; and whatsoever thing Is touched therewith it turns to stone. (15.343-5)
} 
comprises the poem's initial green world. Pulter's spring, then, wreaks a very specific form of commemoration, preserving the artifacts of a royal golden age in a material which will survive man's mortal disruptions. Gray's Spring may thus be compared to an alembic with a faulty Hermes seal. ${ }^{87}$ Its watery womb works not to concoct new life out of base material but, in a defensive use of the womb, to immortalize the bygone as a melancholy survival to the shame of future generations. In this respect, Gray's Spring embodies the same paradox of triumphant stagnation as the Niobic statue.

1646 was a cruel year for Pulter: as well as the imprisonment of Charles I, it brought also the loss of her adult daughter Jane to smallpox. "Upon the Death of My Dear and Lovely Daughter, J.P.”, one of the poems penned in response to this sad event, sees Pulter's lost object switch from the outward-facing one of Charles and his regime, to the private vision of her daughter's body ravaged by disease. ${ }^{88}$ Pulter pictures the fever's assault on Jane's body as a battle of scarlet against white, colours which alchemical theory places in correspondence with the figures of the patriarch and the innocent, respectively (Bayer 7). In the blighting of the Jane's pale body by smallpox, Pulter portends both her daughter's expiry and a state of physiological contamination which extends to a wider maiden collective.

Pulter begins "Upon the Death" by recalling her daughter's "virgin soul” (12), “milky limbs" (11), “snowy skin" (37), and “sparkling diamond eyes” (25), pulling into the poem's orbit numerous other images of brightness to reflect the luminescence of her mourned subject ("Jews, or Chinesses in snowey white" [10], the "illustrious sun" [27], and so on). But though Pulter declares outright that her daughter's "soul doth end in

\footnotetext{
${ }^{87}$ The analogy of womb and alembic was a common one in the Renaissance, both spaces associated with the hermetically-sealed creation of new life (Archer 3).

${ }^{88}$ I use Sarah C.E. Ross and Elizabeth Scott-Baumann's complete version of the poem, from Women Poets of the English Civil War (Manchester University Press, 2018), pp. 108-9.
} 
endless glory" (34), she cannot but replay the infection which has desecrated Jane's body and terminated her worldly existence, thus herself dotting Jane's "spotless virgin story" (33) with blood. A telling "Yet" - Pulter's typical cue for further complaint - sees her poem move from straightforward panegyric to a rumination on sexed corporeality:

Yet my afflicted, sad, forsaken soul For her in tears and ashes still doth roll.

Oh could a fever spot her snowy skin,

Whose virgin soul was scarcely soiled with sin!

Ay me it did; so have I sometimes seen

Fair maidens sit encircled on a green,

White lilies spread when they were making posies,

Upon them scatter leaves of damask roses.

E'en so the spots upon her fair skin show,

Like lily leaves, sprinkled with damask Rose ... (35-44)

The poem's eroticised language and imagery as good as equates Jane's contraction of smallpox with unwilling coitus. The emphatic line "Whose virgin soul was scarcely soiled with sin!'(38) is - if not steeped in Niobic pride - at least offered in a tone of maternal obstinacy, as if Pulter's speaker had expected Jane's chastity to act as a sufficient guarantor against assaults both sexual and virological. (The spectre of venereal disease, of course, is just one figural stop away). Jane's body under its hot fever is mapped out as a desecrated site, the young woman's mistake not her surrendering of virginity as such, but rather her inability to "sad" the internal networks of the body to outside threats. The incursion of blushing petals into the maidens' white circle of posies is framed, in accordance with Jane's despoiling, as a sacralisation of innocence, petals imaged as pockmarks on skin of lily-white.

Unfirm, Jane's body becomes as vulnerable as a deer in the chase, compared to

a stately hart to death pursued

By ravening hounds, his eyes with tears bedewed, An arrow sticking in his trembling breast;

His lost condition, to the life expressed.

So trips he o'er the lawns on trodden snow,

And from his side his guiltless blood doth flow;

So did the spots upon her fair skin show 
Like drops of blood upon unsullied snow ... $(45-52)^{89}$

Although, in this, Pulter makes metaphorical rather than narrative use of the hunt, her deployment of the conceit opens up a clear dialogue between "Upon the Death" and Andrew Marvell's “The Nymph Complaining For the Death of Her Fawn”, which also treats of the loss of an animal object. ${ }^{90}$ Marvell's poem, too, explores the maternal tendency to fetishize innocence, its complaining nymph imagining her faun to "[wax] more sweet and white" (58) than even her own ivory fingers. A mingling of sensual red and white both prefigures and retrospectively visualises the faun's fatal shooting:

It like in a bank of lilies laid.

Upon the roses it would feed

Until its lips ev'n seemed to bleed:

And then to me "twould boldly trip.

And print those roses on my lip.

But its chief delight was still

On roses thus itself to fill:

And its pure virgin limbs to fold

In whitest sheets of lilies cold.

Had it lived long it would have been

Lilies without, roses within. (82-92)

Perhaps the faun did not live long because its insides were turning rosy. The faun's internalisation of, and infection by, red roses opposed to virginity seems to invite into the nymph's pastoral idyll the troopers which will shoot the faun to its death. Jane Pulter's fever performs a comparable operation in her mother's poem, besmirching her body and taking her life via internal penetration.

Almost as a gesture of consolation to their lost objects, our female mourners appear to take on the onus of abstinence and restraint that was previously the foremost

\footnotetext{
${ }^{89}$ This conceit opens up a political reading of "Upon the Death" (Charles I as the hunted "hart"). For more, see Sarah C.E. Ross' article, "Tears, Bezoars and Blazing Comets: Gender and Politics in Hester Pulter's Civil War Lyrics", Literature Compass, vol. 2, no. 1, 2005, pp. 114.

${ }^{90}$ Critics have longed noted the parallel between Pulter's and Marvell's poems. See, for example, Peter Davidson in the Times Literary Supplement, no. 5044, 1999, pp. 14-15, and Nigel Smith's gloss to the Longman edition of "Nymph Complaining", p. 71, note 116. Marvell and Pulter moved in proximate literary circles (see Britland 10-13).
} 
commission of their young wards. They achieve this feat by armouring their own maternal bodies until they no longer exhibit any sign of the porousness and vulnerability which Galenism gave unto the female form. The nymph of Marvell's poem expresses a final desire that she be "cut in marble; and withal / Let it be weeping too" (111-2), requesting also that at her feet "shalt [the fawn] be laid, / Of purest alabaster made" (119-20). And Pulter ends her poem upon Jane's death by incanting a Niobic change:

Her soul being seated in her place of birth

I turned a Niobe as she turned earth. (49-50)

These final acts of self-marmorisation enshrine both maternal voices of melancholy within a stone that speaks - of anatomical impermeability and, in that, of a kind of vicarious retribution for the harm done their innocent scions.

But where Marvell's nymph expresses a final wish to monumentalize not only herself, but the faun also, Pulter's self-marmorisation is closely attended by her shifting of Jane's body from the "diamond" realm of materials to that of dirt, dust, earth ("I turned a Niobe as she turned earth"). This is not, however, a relegation. If diamond is one of the noblest substances in alchemical theory, then dust is its equivalent in Christian doctrine. The prime state of matter for ascension heavenwards, we will see in Chapter Three, is dust. Many of Pulter's other poems venerate dust in this way, connecting it always with soteriological visions of transcendence. ${ }^{91}$ Jane's bodily degradation to earth at the end of "Upon the Death" can thus be revised as a consoling affirmation of her pain's transience, and of the prize afforded her "virgin soul" in the afterlife. For herself-as-speaker, on the other hand, Pulter halts both the eschatological cycle of states (flesh, to dust) as well as the alchemical (nigredo, to rubedo) at the point of albedic marmorisation.

\footnotetext{
${ }^{91}$ I do not intend to present Pulter's tendency to marmorisation in "The Invitation" and "Upon the Death" as representative of her whole poetic corpus. As Ruth Connolly notes, Pulter's poetry features "endless revolutions of matter and spirit through the stages of birth and death, disintegration and regeneration" (1).
} 
As Lyndy Abraham writes, "In alchemy, that which is cold and white is completed by that which is warm and red" (Marvell and Alchemy 293). This process is one and the same with the "chemical bedding" of the white woman and red man as mentioned earlier. It is the final step in the alchemical process, signalling the achievement of the magnum opus, and the alchemist's nearness to the creation of the philosopher's stone. Pulter, though, has reason to pause before her movement to the transcendent - and hermaphroditic - prima materia. Pulter's poetic speaker opts instead for an honourific mourning practice which, consolidating femininity and extending grief interminably, makes out of her own female form a memorial stone not only to her lost daughter, but for all her departed "Niobids". Because Jane's death is, for Pulter, yet another shock. The expansion of her collection of lost objects - here, children - threatens to abstract grief, to afford it a quality of the surreal or absurd: one son or daughter lost, and then the next falls. Pulter must consolidate her maternal affect within her own body, petrifying her form to the spot, making herself the site of remembrance. Pulter's explicit identification with Niobe subverts alchemical practice and belief by intentionally halting the cycle of states at a point of mineralisation that, by entombing life, embodies death. The white stone produced of albedo may an exquisite artifact, but it is not a productive one: it is a philosopher's stone which accepts its state as concrete, as material - and which finds in that very materiality the opportunity to make a mother's grief eternal.

\section{Conclusion}

That Renaissance melancholics regularly declared themselves enamoured by nonexistence is a given. The mode by which this imagined removal of the self from reality is achieved, however, is just as important. Time and again, we read of Aristotelian (that is, male) melancholics wishing for the disintegration of their physical form into dust, water, or a similarly atomized substance. Recall Hamlet's wish that his "too, too solid flesh" 
would "Thaw, and resolve itself into a dew" (1.2. 129-30), Donne's assertion of the transience of all things in "The Dissolution", or George Herbert's conclusion that "That flesh is but the glass, which holds the dust / That measures all our time; which also shall / Be crumbled into dust" ("Church-monuments" 20-22). Dissolution emerges as the choice means of the male melancholic's self-diminution, with the intrusion of more solid materials deemed to "spoil the meeting" (Herbert 14) of dust with dust. Douglas Trevor terms this tendency material idealism, connecting the male melancholic's drive to selfdissolution with angelic corporeality and Neoplatonist pretentions to transcendence. "[O]vercoming base matter with an ascendant mind" (Philippy "CChain'd up in Alabaster"' 215), the male melancholic strove to achieve via material disintegration a higher state of non-being.

Female marmorisation of the kind I have traced in this chapter utterly opposes the widespread tendency to self-dissolution which distinguishes contemporaneous manifestations of male melancholy. The female melancholic is allied, instead, with an alchemical process that binds all atoms together to the purpose of mineral permanency. She valorizes stone for its durability, for its speaking silence, and so she makes that stone the substitute for the philosopher's stone which would fully enliven the self. What might otherwise have been interpreted as occasional grief hereby metamorphoses into an almost competitive stance of female melancholy which both celebrates and transcends the prevailingly-material conceptualisation of women's mourning.

It is worth returning, in this chapter's final paragraph, to marmorised melancholy's ethical, even its theological, status. In one respect, this type of metamorphosis seems a removal of the self to the condition of death-in-life against which Donne so rails, and to an irreligious condition of melancholy which goes against timebound mourning codes. But this marmorisation, if indeed a removal of the self, is one 
which extends that self's chronology, stretching the duration of melancholy in stubborn resistance to consolation. Self-marmorisation hence emerges as a choice to preserve life beyond its natural end, as a refusal to relinquish the corporeal experience of being woman, and as a thoroughly-modern favouring of obstruction (a conception of the body or self as a hermetically-sealed container) that protects the orificial female vessel from events like childbirth and loss. If the poetry of self-dissolution works to "dissolve, discredit, reinterpret, rearrange, and otherwise compromise the material existence of the speaker" (Harman 111), then marmorising poems do the opposite - showing us fear not in a handful of dust, but in a body of stone. 


\title{
3. Postlapsarian Melancholy and the Woman Poet
}

\author{
Allegories are, in the realm of thoughts, what ruins are in the realm of things. \\ - Walter Benjamin, \\ The Origin of German Tragic Drama
}

It is a miracle of grace and mercy, if such be not deprived of the light of Truth, who having shut their eyes against that sun, have, instead of looking up to it, hunted glow-worms in the ditch bottoms.

In her foundational work on melancholy, Black Sun (1981), Julia Kristeva introduces the depressed person as "a radical, sullen atheist" (5). Kristeva is certainly not the only philosopher to posit melancholy as the affective jurisdiction of the nonbeliever; the assumption of the melancholic's disenchantment with Christian doctrine has all but defined modern discourse on the subject. A romp through the canon of Western literature and philosophy appears to prove this assumption true. Whether in Keats' "Ode to Melancholy", Nietzsche's nihilistic philosophy, or Sartre's Nausea, melancholy seems to follow from the realisation that meaning, if it is to exist at all, must be fashioned ex nihilo amidst a vacuum of godlessness. And of course innumerable commentators, rifling through the archive for a figure who sees nothing but black oblivion beyond death, settle upon Hamlet as the melancholic subject par excellence. But is a dearth of prescribed meaning - I mean the absence of a patterning belief-system - necessary, or even typical, to the experience of early modern melancholy? Secular modernity's championing of a 
character like Hamlet overlooks the fact that he hails from an age in which the states of extreme religiosity and melancholy were, for women as much as for men, far from mutually exclusive.

Problematizing any modern conception we might hold of Hamlet as a protoatheist, Walter Benjamin argues that the prince's melancholy disposition can be explained as a response to the philosophy of the University of Wittenberg, his alleged alma mater. As the seat of Martin Luther, Wittenberg was the hub also for sixteenth-century Reformation theology. This theology, claims Benjamin, can be causally related to Hamlet's melancholy on account of its inherently pessimistic view of the fallen world. Under this branch of Protestantism,
Human actions were deprived of all value. Something new arose: an empty world ... There was no answer to this except perhaps in the morality of ordinary people - 'honesty in small things', 'upright living' - which developed at this time, forming a contrast to the taedium vitae of richer natures. For those who looked deeper saw the scene of their existence as a rubbish heap of partial, inauthentic actions. (Benjamin 138-9) $)^{92}$

With Lutheranism promoting all that was worth having or enjoying to a world above that of the human, and leaving the dubious organizing principle of asceticism as substitute, how could the believer's affective response be anything save a melancholy which devitalised every human act of its significance?

Hamlet, then, may not be so irreligious a figure after all. The same is true of early modern melancholy's female sufferers, who have historically been denied their coterminous religious identities. Katharine Hodgkin highlights how "debates over women and melancholy [in early modern England] have taken place predominantly in relation to secular representations of melancholy" ("Scurvy Vapours" 8). This thesis has so far

\footnotetext{
${ }^{92} \mathrm{Cf}$. Anthony Kemp: "If the Reformation was a movement of great religious revival, it also contained within itself the opposite tendency toward Deism and the withdrawal of God from religious experience" (81).
} 
followed such debates by concentrating on forms of melancholy which approach the secular. Ophelia's and the Jailer's Daughter's culturally-assembled erotomania sits on the opposite side of the spectrum to devout melancholy, and the marmorised affect discussed in the preceding chapter cannot be comfortably allied with Christian mourning. Even An Collins' melancholy is not in itself religious: whilst the consolations which book-end her poems are indubitably devout, they are invoked as cure, hence obscuring the content of her "true" melancholy. One of the tasks of this last chapter, therefore, is notionally to account for the missing space of complaint that Collins' poetry leaves, and to testify to the forceful presence of religious ideology in literary expressions of female melancholy. Because as Hodgkin also notes, the early modern experience was one "shaped by and articulated through assumptions about God and the devil, providence and divine punishment, religious melancholy and despair" - a claim to which the vast majority of seventeenth-century women's personal accounts of melancholy testify (8).

When scholars such as Hodgkin have considered melancholy's religious dimensions, they have gravitated towards the brand of religious melancholy that is descended from the medieval sin of acedia, or what Juliana Schiesari defines as "the soul's laxity with respect to its spiritual duties to God" (154). ${ }^{93}$ Burton discusses this type of religious melancholy with characteristic vigour in the Anatomy of Melancholy. Dedicating an entire section of his work to "Religious Melancholy", Burton unequivocally blames the "grand sinne of Atheisme" (3:340) as the cause of this "monstrous" mode of affect, and describes its victims as those who "love the world too much; God too little" (3: 337). ${ }^{94}$ Since Burton's time of writing, religious melancholy has overwhelmingly been defined according to the supposed relationship between negative

\footnotetext{
${ }^{93}$ For more on acedia, refer to Chapter One, pp. 45-6.

${ }^{94}$ Notably - especially when applied to this thesis' first chapter - Burton includes himself within this category.
} 
affect - the emotions of sorrow, guilt, and fear all coalescing as "melancholy" - and a clear turning-away from God.

However, this definition overlooks the innate co-occurrence of negative affect and unerring belief in early modern Christianity. Protestant doctrine, by shifting value from earthly joys and toys to the wayfaring Christian's private relationship with God, is known to have foregrounded the importance of negative emotion. "Forced continually to the recognition of their moral insufficiency and corruption", writes Jeremy Schmidt, "the spiritually minded believer cultivated a fear and sorrow appropriate to the acknowledgement of human worthlessness as both the substance of godliness and the means of certainty to salvation" (54). It was not only the "introspective inclinations of the Reformation and Counter-Reformation" which "heightened self-consciousness and personal experience", Swiss and Kent note, but so too the influence of the Renaissance cult of melancholy (8). The affective condition produced out of the collision of the two was melancholy still, but melancholy as an outgrowth of faith; not related to a "sinful disposition", but rather to the "impasse between the desire for union with God and the feeling of hopelessness deriving from the taedium vitae that endlessly deferred this goal" (Agamben, as paraphrased in Schiesari 98). Rather than serving to indicate a lapse in faith, therefore, the presence of melancholy feeling could be understood instead as a proof of belief in the Lapse, and thus as the natural affective mate of the postlapsarian condition. Accordingly, this chapter operates according to the notion that the zealous belief in the Edenic Fall as it is written in the Old Testament - and the conviction of mankind's utter concupiscence thereafter - is a religious doctrine which generates a uniquely postlapsarian form of melancholy.

Of the many religious women writers whose verse communicates this postlapsarian melancholy, Lucy Hutchinson (1620-1681) is both representative and 
outstanding. ${ }^{95}$ Hutchinson has long been lauded for her translation of Lucretius' De rerum natura, and for her authorship of Memoirs of the Life of Colonel Hutchinson, the classic work of seventeenth-century biography. Largely thanks to the efforts of David Norbrook in recent decades, Hutchinson's two poetical works, Order and Disorder (1679) and the "Elegies" (1667-8), have also emerged as favourite academic texts. ${ }^{96}$ I base my discussion in this chapter around the "Elegies", whilst drawing also on Hutchinson's verse retelling of Genesis, Order and Disorder, and Milton's Paradise Lost (1667). The latter two texts tell of prelapsarian bliss and postlapsarian loss through the familiar biblical figures of Adam, Eve, and their issue. Hutchinson's "Elegies", I argue, do much the same, but in the language of personal grief, and via the allegorically-placed figures of Hutchinson and her deceased husband. Weaving together Neoplatonic imagery and Christian typology, Hutchinson brings about in the "Elegies" a world-splitting which results in exactly the "rubbish-heap" (Benjamin 139) view of human existence that Protestant theology authorised.

\section{Melancholy after the Fall}

When Gary Kuchar claims that "Christianity is nothing if not a vast technology of mourning" (I), he condenses into a phrase the progression of suffering that was thought to begin with Adam and Eve's expulsion from Eden, achieve its apogee in the passion of Christ, and replay in perpetuity for all mortals thereafter. It is this lesser-advertised brand of religious melancholy that hides amidst the quotational patchwork of the Anatomy of

\footnotetext{
${ }^{95}$ Other women poets whose verse overtly alludes to the Fall and its consequences include Anne Bradstreet, Alice Sutcliffe, Jane Cavendish, Aemilia Lanyer, and Ester Sowernam.

${ }^{96}$ A crusade so effective, in fact, that by Norbrook's own admission, the Memoirs has "fallen into eclipse" in recent years (Norbrook, "Theology, Gender, and Translation" 142).
} 
Melancholy's beginning, far prior to Burton's lengthy exposition on the "Religious Melancholy" with which we are better acquainted. It reads:

But this most noble Creature [Man], heu tristis, \& lachrymose commutatio (one exlaimes) $O$ pittifull change! is fallen from that he was, and forfeited his estate, become miserabilis homuncio, a cast-away, a catiffe, one of the most miserable creatures of the World, if he be considered in his owne nature, an unregenerate man, and so much obscured by his fall that (some few reliques excepted) he is inferiour to a beast. Man in honour that understandeth not, is like unto beasts that perish, so David esteemes him: a monster by a stupend Metamorphosis, a fox, a dogge, a hogge, what not? Quantum mutatus ab illo? How much altered from that he was, before blessed and happy, now miserable and accursed [.] (1:122)

Here in Burton, as in many religious writers before and after him, Adam and Eve's misstep in Eden is presented as the font of all ensuing misery. Indeed, far prior to the Anatomy, melancholy was understood as a leading affective consequence of the Fall. One of the first writers to forge this correlation was St. Hildegard of Bingen (1098-1179), the only recorded premodern female commentator on melancholy. Before Adam ate of the fruit, alleges Hildegard,

what is now melancholy in man shone in him like the dawn and contained in itself the wisdom and perfection of good works; but when Adam broke the law, the sparkle of innocence was dulled in him, and his eyes, which had formerly beheld heaven, were blinded, and his gall was changed to bitterness, and his melancholy to blackness. ${ }^{97}$

From this, Juliana Schiesari concludes that Hildegard views melancholia as "an essential and inescapable condition of all post-lapsarian human existence, a condition of sin itself" (156). However, Schiesari then connects this kind of guilt-induced melancholy to scepticism and even to ignorance of God, which I am more reluctant to do (155-6). It is my purpose in this chapter, instead, to pursue a religiously-motivated melancholy which has as its core criterion not the acedic's self-punishing complaint regarding her own "grand sinn of Atheisme" (as Burton puts it), but rather a religious melancholy produced

\footnotetext{
${ }^{97}$ As quoted in Klibansky, Panofsky and Saxl, p. 80.
} 
by or framed in terms of the seventeenth-century believer's engagement with Old Testament scripture.

For the postlapsarian melancholic, the Fall is the pre-structure of understanding which comes to determine and totalise all subsequent perceptions. The literary content of the Bible "creates the supernatural world in the imagination, exerts almost absolute precedence over any merely empirical knowledge" (Kemp 111). Of this literary content, the idea of primal innocence becomes the curiously-detached object of loss for which religious life on earth is a protracted experience of mourning. As Kuchar writes, "original sin, and with it the world of the flesh, can be part of experience but not part of consciousness; the human subject is constituted between sinful forgetting and impossible remembering" (201). ${ }^{98}$ The famously-melancholic Luther adds food to this theory, writing in his Commentary on Romans that the iniquity of original sin "enters into us; we do not commit, but we suffer it. We are sinners because we are the sons of a sinner" (95). ${ }^{99}$ Luther does not recognise the original sin as his crime, exactly, and yet it has the force of an episteme, a regime of knowledge that shapes his being in the world. Lucy Hutchinson's theological treatise, "On the Principles of the Christian Religion", communicates a similarly deterministic view of fallen existence:

Corruption is [man's] mother and the worme his father; that blood that dances so pleasantly in the vaines is loathsome pollution; when the vitall fire ceases to boyle it, the pampered praised idolized flesh turns into wormes and rottennesse. were not this glory such a glowworme such an ignis fatuis such a falling starre which blazing in its descent is found upon the ground a corrupt gelly yet hath he no

\footnotetext{
${ }^{98} \mathrm{Cf}$. Paul Ricoeur on the curious distance between the subject and the loss of innocence as related to Adamic myth: "The idea is suggested of an evil that was always already there in experience and yet is fundamentally contingent in the primordial order. It is philosophically interesting in that a distance is established in this way between the agent and the action. The action is henceforth universally reputed to be evil and as such universally deplorable and deplored. But something of the subject is exempt from this ..." (465).

${ }^{99}$ Cf. David, in Psalms 51:5: "Behold, I was brought forth in iniquity, and in sin my mother conceived me" (679).
} 
reason to esteeme himselfe for himselfe for he is not his owne hath no power in nor over himself ... (254)

In Hutchinson's evocative summary of man's corrupt and transient condition, the subject assents to the belief that "he is not his owne", has "no power in nor over himself". It is this - each individual believer's abstract self-identification with the dramatis personae of Genesis, their adoption of an irretrievable memory as a patterning ontology - which creates the religious culture of guilt and worldly melancholy that Hutchinson imports into the "Elegies".

As has been stated in Chapter 1, however, ardently-Puritan writers were apt to view melancholy as another of the indulgences, and so in many cases to ascribe excessive melancholy to apostate actors. ${ }^{100}$ But the strain of sadness and mourning which permeates religious writers' ruminations on the Fall is indubitably, is almost by definition, melancholic. ${ }^{101}$ It is simply a melancholy that dares not speak its name. By virtue of this subtle treatment, the religious writer heralds with their commentary on worldly exile the abstraction of melancholy from the body to the wider poetic landscape. Postlapsarian melancholy is not a melancholy comprised of references to black bile, coagulating bodily fluids, and the triumphant ability to philosophize; it is instead much closer to an affective mood, to a pathetic fallacy which pervades both the mortal body and its earthly environs. This kind of melancholy emanates not from the spleen, but from the faculty of memory itself.

\footnotetext{
${ }^{100}$ See David Norbrook's footnote 231 in Order and Disorder, with reference to the tale of Lot: "Excessive melancholy was a familiar theme of anti-Puritan writing; Sylvester has the Sodomites term Lot a 'Puritan"' (172). See also Femke Molekamp: "Excessive grief, like melancholy, was rejected by philosophical systems in the early modern period as pernicious" (141).

${ }^{101}$ Cf. Julius Rubin: "the Puritan theology of conversion, the practice of piety, and the ethos of innerworldly asceticism structured experiences of melancholy" ("Melancholy" 294).
} 


\section{The "Elegies": An expanding object, and a garden in ruins}

Elegies are acts of memory-work, and in hers, Hutchinson seeks "both to mourn something that has been lost to her, and to ensure its continuing existence through her writing" (Chedgzoy 153). This something is, for Hutchinson, her spouse. John Hutchinson died imprisoned in Sandown Castle in 1664, following arrest for his part in the regicide of Charles I. The "Elegies" seem to date to at least a few years after his death, evidencing the protracted process of grief undertaken by the widowed Lucy Hutchinson during her retirement to the family estate of Owthorpe. Appositely, Hutchinson's reception of her husband's death in the "Elegies" has been described in terms of circular obsession and inertia. For example, Elizabeth Scott-Baumann notes that with the elegies Hutchinson forges a new poetics of "grief, absence, and loss" ("Lucy Hutchinson's Elegies" 147); Erica Longfellow discerns a "circling around grief in an attempt to understand the process and keep hold of that which is lost" (192); Susan Wiseman states that "the poems refuse consolation in part by their pointed refusal to relinquish the beloved as a sexual object" (212); and finally, Sarah C.E. Ross writes that the elegies "Circl[e] inconsolably around John Hutchinson as the elegiac subject" (“"I see our neere ..." 175). Elise Lonich Ryan comes closest to diagnosing the "Elegies" as melancholy when she remarks that the lost object of John is at once omnipresent and "difficult to grasp", a "disappearing signifier" who, though he "animates both Lucy’s consciousness and her poetic forms" (222), remains but a shadow. Despite her enigmatic comments, however, Ryan settles upon the descriptor of "melancholy" only at the very end of her article on the "Elegies". Ryan is not alone, as melancholy is rarely applied to the poems even adjectivally. I already depart from existing critical interpretations, then, in reading the "Elegies" as expressions of pronounced melancholy. I differentiate my reading further 
by positing that Hutchinson espouses in her poetic series a distinctly postlapsarian mode of the affect.

Like Hester Pulter's act of self-marmorisation in honour of her daughter, Hutchinson's elegies for her husband go beyond occasional mourning to make of John's loss a temporally-insurmountable and ever-expanding event. In words not unlike a certain Danish prince's, Hutchinson refuses in her fourteenth elegy to cut her mourning short:

As mourners who Their blacks Cast by

New flowers The bankes \& trees adorne

But still greifes Sable Levery

In my Sad heart \& Eies is worne ... (17-20) ${ }^{102}$

The typical mourner might be able to cast their nighted colours off, but for Hutchinson "griefes Sable Levery" is more than a temporary accessory. She wears it over her eyes, and it veils her view of the new life that better seasons might bring. ${ }^{103}$ Through such a melancholy lens, every element of the poetic landscape is transformed into a form, mood, and shape of grief.

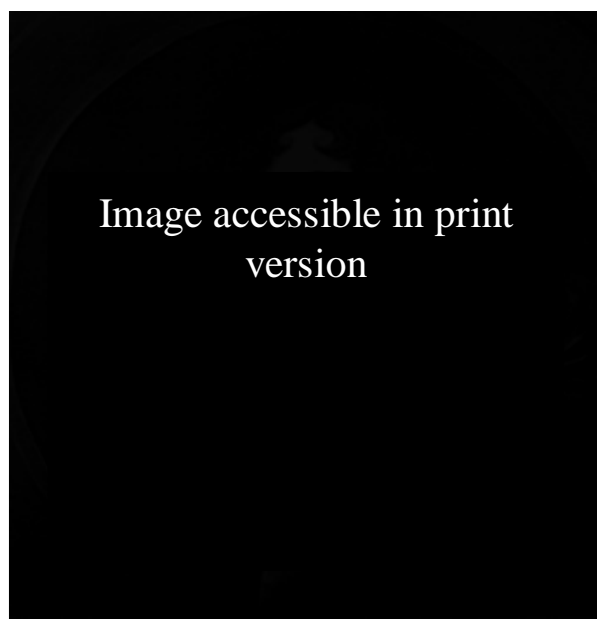

Figure 5: The Nottinghamshire Castle Museum portrait of John Hutchinson.

\footnotetext{
${ }^{102}$ I quote directly from David Norbrook's text of the "Elegies", attached to his article "Lucy Hutchinson's 'Elegies' and the Situation of the Republican Woman Writer".

${ }^{103}$ Cf. with Hamlet's "veilèd lids" (1.2.70).
} 
Hutchinson's myth-making is at its most transparent in the elegies which have the garden at Owthorpe at their centre. Imprinting in every unkempt corner the absence of its primary tender (John Hutchinson, as the type of Adam), the garden is a clear analogue of Eden following the expulsion of its human labourers. Elegy 7 begins by surveying a past scene replete in "shining frutetrees" and youthful exuberance - but too soon arrives the pitiful change:

... he is gone \& These gone w: $:^{\text {th }}$ him too

Let now Thy flowers rise Chargd $\mathrm{w}^{\text {th }}$ weeping dew

And missing him shrink back into their beds

Soe my poore virgins hang Their drooping heads

And missing $\mathrm{y}^{\mathrm{e}}$ deare object of their sight

Close vpe Their Eies in Sorrows Gloomy Night

Let Thy young trees wh: $:^{\text {ch }}$ sade $\&$ fading stand

Dried upe Since They lost his refreshing hand

Tell me too sadely how $\mathrm{y}:{ }^{\mathrm{r}}$ noblest Plant

Degenerates if it vsuall Culture want (16-26)

As David Norbrook comments in his preface to the modern edition of the "Elegies", Hutchinson here casts herself - and, by extension, the garden - "as Milton does his Eve, depending on her husband's support" (476). An Eden without its master, evidently, is an Eden no more. The elegy continues:

Too much alas This Parallil I find In $\mathrm{y}^{\mathrm{e}}$ disordred passions of my mind But Thy late louelinesse is only hid Mine like $y:^{\mathrm{e}}$ shadow with its substance fled Annother Gardiner \& another Spring May into $\mathrm{y}^{\mathrm{e}}$ new grace $\&$ new lustre bring While beauties seedes doe yet remaine aliue But ah my Glories neuer can reviue (31-8)

In this second extract, Hutchinson refers to the psychical "Parallil" which impels her to relate the garden's degradation to her husband's passing and, beyond that, to the loss of Eden. It is this inescapable urge to analogize - to allegorize - which keeps Hutchinson from the future regeneration that she extends to other parties in the quickening couplet at lines 35-6. In contrast to so many biblically-layered poems, Hutchinson's “Elegies" lack 
the polemical or didactic impulse which applies the allegorical map of the Fall in order to impress the whole of mankind's sinful condition. Here and elsewhere in Hutchinson's "Elegies", the offering of utopian promise to the prospective new inhabitants of the Owthorpe estate indicates the poet's awareness of where her own melancholic subjectivity ends, and thus where the subjectivities of other, unjaded individuals begin. ${ }^{104}$ “Annother Gardiner \& another Spring / May into y new grace \& new lustre bring”, reads Elegy 7 ,

But ah my Glories neuer can reuiue

No more $y:^{\text {n }}$ new leaues or new smiling fruite

Can reinvest $\mathrm{y}^{\mathrm{t}}$ tree Thats dead at roote

To me That resurrection would be vaine

And like vngathred flowers would die againe

In vaine would doting time $\mathrm{w}^{\text {ch }}$ can no more

Giue Shuch a Louer Lovelinesse restore (38-52)

Clearly, Hutchinson's own consciousness is closed to affective renovation. With trees "dead at roote" and "Lovelinesse" impossible to restore, Hutchinson's central garden elegy announces her artistic and epistemological failure to reconstitute a primordial landscape of innocence. Left behind is an accumulation of signs which refer only to what has been lost - sketching nothing, in sum, but a "field of ruins" (Mosès 100).

When the elegiac object disappears, his or her memory traces are firmly embossed on the mourning subject's realm of thought. Such an extenuation of mourning puts into motion the alteration of the lost object from what it once may have been, to something far less containable and definable, something more. ${ }^{105}$ Since under the influence of

\footnotetext{
${ }^{104}$ As in Elegy 11, towards the end of which Hutchinson acknowledges the particularity and insularity of her own habitus of grief:

But new Inhabitants may restore

The grace $\&$ beauty This Place had before

I a Polluted Pallace must remaine

No ornaments can decke me vp againe (48-55)

${ }^{105}$ For more on the melancholic's creative relation to their lost object, refer to the introduction to this thesis (p. 16).
} 
melancholy "one cannot see clearly what it is that has been lost" (Freud 245), the melancholic subject is driven to erect an impersonal, mythologizing scaffold around their object of desire - a scaffold which augments woe by adding alien content to it, hence justifying the mourner's inability to cast off grief. Hutchinson might not be able to access the knowledge of Eden as it once was, but she can in the elegies call on her impressed memory of the marital bliss she enjoyed prior to her husband's demise to evoke the loss of innocence which ruins her subjective world. The passing-away of Hutchinson's personal paradise with the loss of her husband is thus not a loss which remains terrestrially located, but one which is absorbed into a loss of inestimably biblical proportions. Due to his status as a "disappearing signifier" within Hutchinson's melancholic discourse, the emblem of John can cope with this kind of allegorical inflation, with this rewriting as a central figure in Christian eschatology.

\section{Shadowy types}

In one of the epigraphs to this chapter, Walter Benjamin asserts that "Allegories are, in the realm of thoughts, what ruins are in the realm of things" (178). Although Benjamin's statement is directed toward baroque tragedy, Hutchinson's poems invite the same treatment. In the "Elegies" as much as in a baroque tragedy like Hamlet, the forms and shapes of fallen reality are "like a play of hieroglyphs hiding no meaning" (Mosès 99). For Hutchinson, John's death further fissures the earthly field of ruins from the celestial world of Ideas, and hence the prevailing aesthetic of her elegies emerges as one of barrenness and impoverishment, of allegorical landscapes always desiring better content.

As Benjamin recognises, the nature of this desire is both biblical and Platonic. The synthesis of the two, of course, was the work of Renaissance culture. As has been briefly alluded to in this thesis' introduction, Marsilio Ficino, the chief proponent of scholarly melancholy in the European Renaissance, is also now celebrated for his role in 
repackaging Platonism for the Christianized West. Such a project involved the devaluation of matter in favour of things incorporeal, in an effort to clamber heavenwards to the One. ${ }^{106}$ The same philosophical orientation is shared by Lucy Hutchinson and John Milton, for whom Christian belief presents no hindrance to their engagement with Neoplatonic discourse. Indeed, the latter is in many respects a testament to their strength of faith in the former, for it is the ultimate show of religious deference to depreciate earthly copies against their perfect ur-models. ${ }^{107}$

Perhaps the most famous passage in support of this idea is from Book 5 of Paradise Lost, where the angel Raphael stops to ponder how to translate divine notions into Adam's lower register:

what surmounts the reach

Of human sense I shall delineate so

By lik'ning spiritual to corporal forms

As may express them best. Though what if Earth

Be but the shadow of Heav'n and things therein

Each to other like more than on Earth is thought? (571-6) ${ }^{108}$

Order and Disorder constructs a similar dialectic, this time between derivative earth, and perfect eternity:

in God's visible productions we

What is invisible in some sort see;

While we, considering each created thing,

Are led up to an uncreated spring,

And by gradations of successive time

At last unto Eternity do climb (1.65-70)

\footnotetext{
${ }^{106}$ See Klibansky, Panofsky, and Saxl: "from the system of humours in Galen and Aristotle, in Ficino we come to a platonizing of the melancholic genius, a new vision of the melancholic man as one whose quest for knowledge is inspired by an eros that finds his desire for a relationship with the transcendent" (115).

${ }^{107}$ For more on the principles of Christian Neoplatonism, see Pauliina Remes, "The Neoplatonic Legacy", Neoplatonism, Routledge, 2008, pp. 199-208. See also Lewalski: “Augustinian allegorical exegesis is based firmly upon a Platonic conception of mimesis in which all things and all linguistic forms are symbols of a reality which transcends them but to which they may help to elevate the soul. The movement is through words to a silent, intuitive grasp of divine reality" (75).

${ }^{108}$ I quote from the 2005 Norton edition of Paradise Lost, ed. Gordon Teskey.
} 
As is made clear in both Milton's and Hutchinson's accounts of Neoplatonic reality, the ambition to climb beyond the terrestrial to a place of full and unadulterated presence is every Christian's to covet, even if that knowledge is not rightfully theirs to possess.

In Paradise Lost, however, Milton's narrator temporarily overcomes his lack of knowledge of the Forms to take up, with the aid of his Muse, the task of picturing the "things" in Heaven. The success of this endeavor is not universally granted (consider especially C.S. Lewis' accusation that Milton tries to make his Heaven "too like Olympus" [131]), but the effort itself is bold, and constitutes a direct contrast to Hutchinson's comparative reticence in Order and Disorder. Hutchinson's retelling of Genesis is narrated by a speaker who regularly halts herself from over-reaching into the world of Forms that she cannot know. In the preface to Order and Disorder, Hutchinson recalls with remorse a youth spent enamored by the work of poets and philosophers who, she claims, wrongfully imagined "the original of things" (3). Realizing her fault, Hutchinson

resolved never to search after any knowledge of him and his productions, but what he himself hath given forth. Those that will be wise above what is written may hug their philosophical clouds, but let them take heed they find not themselves without God in the world, adoring figments of their own brains, instead of the living and true God. (3-4)

A similar attitude receives expression at the beginning of the poem proper, where after briefly musing on the mechanics of Heaven, Hutchinson chastises herself and her reader with the following:

Treating of which, let's waive Platonic dreams Of worlds made in Idea, fitter themes For poets' fancies than the reverent view Of contemplation, fixed on what is true And only certain, kept upon record In the Creator's own revealed Word, Which, when it taught us how our world was made, 
Wrapped up th'invisible in mystic shade. (1.173-80)

Hutchinson's reluctance to climb, via the unreliable faculty of the imagination, beyond the immediately visible is a noble principle. What this commitment to empiricism effects, however, is a redoubling of her dissatisfaction with fallen ontology and epistemology, a "Wrapp[ing] up" of herself in "shade". It is right and just for the Christian believer to confine their ken to what is visible, but this means they irreparably confine themselves to living in the shadows - amidst that "rubbish heap of partial, inauthentic actions" which constitutes the fallen world in the wake of the Reformation. The firmer the subject's belief that truth and beauty exist in a divine elsewhere, the more shadow-like earthly impressions are cast.

There is no better theological "parallil" for this situation - that is, for the melancholy coming-together of Platonic metaphysics and Christian theology - than the theory of biblical typology. Thomas Aquinas famously split the methods of biblical exegesis into four: the literal, the allegorical or typological, the tropological or moral, and the anagogical. ${ }^{109}$ It is the second, figural mode of interpretation which is pertinent to my reading of Hutchinson's "Elegies". ${ }^{110}$ This is because typology, with its reflective pairing of the Old and New Testaments (the first full of mere "shadows", the second their fullyrealized expressions) is thoroughly Platonic. According to a typological reading of the Bible, the events and characters of the New Testament are understood as a curative to those of the old. ${ }^{10}$ The following, a translated quotation from Nonconformist theologian

\footnotetext{
${ }^{109}$ This fourfold method of biblical exegesis was referred to as the Quadriga (see Brownlee 4041).

${ }^{110}$ I here group together and somewhat blur the boundaries of typology and allegory, as was apt to be done by seventeenth-century exegetes. See Lisa Frankiel: "one cannot rigorously distinguish between typology and allegory any more than one can rigorously demonstrate the legitimacy of a given meaning" (Reading Shakespeare's Will: The Theology of Figure from Augustine to the Sonnets [Columbia University Press, 2002]).
} 
John Owen which appears among Lucy Hutchinson's theological writings, testifies to the Puritan stance on typology in the later-seventeenth century: "The old Testament held forth only a shadow without substance in its figures [sic] The new exhibits the truth and substance it selfe". ${ }^{111}$

As in much religious poetry of the seventeenth century, there is a rich sense in both Order and Disorder and Paradise Lost that Old Testament types figure as insolvent shadows, yearning always for their New Testament mates. For example, in Hutchinson's retelling of Genesis, the creation of Eve out of Adam (and their subsequent union) is explicitly presented as the type of Christ's marriage to the Church. ${ }^{12}$ Further, the last two books of Paradise Lost trace how, via a procession of messianic figures, "shadowy types" will move in the New Testament to become "truth", "flesh to spirit", "imposition of strict laws to free / Acceptance of large grace" (12.363-5). Differentiating his religious verse once more from Hutchinson's, however, Milton grants his Old Testament types partial fulfilment. In Paradise Regained (1671), the companion poem to Paradise Lost, Milton details Christ's triumph over Satan in the wilderness - the typological fulfilment, according to Christian exegetes, of Adam and Eve's fatal lapse in Eden. The relation of Paradise Regained to Paradise Lost is thus essentially reparative, restoring at least part of what has been lost, and proving the worth of even mortal virtue. Hutchinson, by contrast, ends her poetic career without fulfilling the prophecies and types that appear in Order and Disorder. Hutchinson's biblical poem may be the last of her works to exhibit a preference for type over antitype, but as this chapter argues, it is by no means the only.

\footnotetext{
${ }^{111}$ Owen, as translated by Hutchinson in Works, p. 38.

${ }^{112}$ As Eve out of the sleeping Adam is formed, Hutchinson prophesies, "So from the second Adam's bleeding side / God formed the Gospel Church, his mystic bride" (3.467-8). Cf. Paul in Ephesians 5:22-23: "Wives, submit yourselves to your own husbands as you do to the Lord. For the husband is the head of the wife as Christ is the head of the Church, his body, of which he is the saviour".
} 
The "Elegies" deny the offer not only of restorative events or figures, but of reparative worlds more generally - and they enact this denial to far more melancholy effect, I contend, than Hutchinson's literalist narration of scripture allows.

To linger briefly on the discussion of typology, it is worth noting that in Christian usage, "type" and "shadow" are synonymous terms. As a case in point, Barbara Lewalski isolates an instance in Hebrews where the word "skia" ("shadow") is employed to describe the "shadows of reality to come in Christ" (112). ${ }^{113}$ This yoking of type and shadow becomes particularly pertinent when one considers Hutchinson's insistent selffiguration across her writings as the shadow of her husband. Hutchinson's depiction of herself in relation to John has historically troubled feminist critics, and on the basis of this oft-quoted passage from the Memoirs, one can appreciate why: ${ }^{114}$

$[\mathrm{H}] \mathrm{e}$ soone made her more equall to him than he found her, for she was a very faithfull mirror, reflecting truly, though dimmely, his own glories upon him, so long as he was present; but she, that was nothing before his inspection gave her a faire figure, when he was remoov'd was only fill' $d$ with a darke mist, and never could againe take in any delightfull object, nor returne any shining representation. (32-3)

Hutchinson's first elegy proffers an extension of the melancholy tale of widowhood that this passage from the Memoirs briefly evokes. With the removal of her cosmos' centre of illumination in John, Hutchinson's own status as a shadow-body is revealed:

Leaue of yee pittying friends; leaue of in vaine Doe you perswade $\mathrm{y}^{\mathrm{e}}$ dead to liue againe In uaine to me $\mathrm{y}^{\mathrm{r}}$ comforts are applied For, 'twas not he; twas only I That died In That Cold Graue which his deare reliques keepes My light is quite extinct where he but sleepes My substance into $\mathrm{y}^{\mathrm{e}}$ darke vault was laide And now I am my owne pale Empty Shade (1-8)

\footnotetext{
${ }^{113}$ See also Penelope Anderson: "Within discussions of typology, 'figure' clusters with 'type' and 'shadow' as the initial term that waits to come to fulfilment" (255).

${ }^{114}$ Hutchinson "has caused difficulties for feminist critics" because her religious affiliations dictate "wifely inferiority and submission" (Longfellow 186).
} 
The movement this verse traces from the collective (those unwanted "friends"), to the Other (John), and then finally to the sole ("I"), is revealing. The stark caesurae which split the first and fourth lines rise like gates to keep other subjects out, and allow the poet to supplant them with isoconolic clauses which are near identical apart from in their eradication of second- or third-person pronouns. The reader advances from the contracted binary of John-versus-Lucy ("twas not he; twas only I that died") to its expanded version in the third couplet, which with its teleological emphasis on the grave's preservative holding of John's bones - note the concurrence of "keepes" and "sleepes" - further underlines Lucy's contrasting assertion of self-extinction in its middle ("My light is quite extinct"). And then, in a curious erasure of the original elegiac object, the last couplet figures a self-interment of sorts, an act of poetic kenosis by which Lucy empties herself of "substance" and steals John's place as the dead body to bury. All other presences are absented save Lucy's own representative signifiers, as the self-as-shadow paradoxically emerges as the star of the elegy. The burdened stresses of "laide" and "Shade" mimic the final dull thumps of Hutchinson's content dropping into the "darke vault", as her subjectivity - merely silhouetted to begin with, as we know - is doubly excavated, rendered the "pale Empty Shade" of itself.

\section{Pale death}

Elegy 1's self-emptying vision demonstrates the cataclysmic effect of John's allegorically-figured loss on the poetic landscape of the "Elegies". Benjamin says of allegory that the authorial deployment of symbol strips the surface-text of meaning, thus confronting the observer with "the facies hippocratica of history and a petrified, primordial landscape" (166). Nowhere is this idea more plainly manifest than in Hutchinson's “Elegies", where John is made the glistening monstrance which renders all else plainly monstrous. Because John, in Lucy's elegies, is made to mean so much more 
than just what he is (made the type, amongst other things, of Adam, salvific death, and ultimately the higher realm), he impoverishes the rest of the elegiac landscape of which he is both the central lack, and the ineffable object of comparison.

To illustrate what I mean by this, it is useful to compare Hutchinson's "Elegies" with a better-known elegy, John Donne's “The First Anniversary: An Anatomy of the World". Written in 1611 to commemorate the death of 15-year-old Elizabeth Drury the year before, "The First Anniversary" features the same bold use of allegorical symbolism as Hutchinson's poetic series. In Donne's elegy, too, the worldly loss of the object of mourning is identified as the sole source of material reality's transformation into a figurative wasteland. ${ }^{115}$ Like Hutchinson treating her husband's demise, Donne finds in Drury's death an opportunity to replay the effects of the original Fall for all mankind. ${ }^{116}$ In order to throw the rest of the earth into postlapsarian shadow, however, Donne must first figure Drury as perfect. He does this first by purging her of the stain of femininity:

She took the weaker sex; she that could drive The pois'nous tincture and the stain of Eve, Out of her thoughts, and deeds; and purify All by a true religious alchemy ... (179-182)

No equivalent gender purification is required of Hutchinson's elegiac object, but this does not mean that the poetic emblem of John is exempt from the "religious alchemy" that transmogrifies Drury from weak vessel to unstained spirit. Hutchinson's sixth elegy, “On the Picture of ye Prisoner", depicts the crossing-over of John Hutchinson from his imprisonment at Sandown to a demesne of divine sublimation. The Bible is the route to

\footnotetext{
115 The continuation of Donne's poem's title reads, rather unambiguously, "Wherein, by Occasion of the Untimely Death of Mistress Elizabeth Drury, the Frailty and the Decay of this Whole World is Represented".

${ }^{116}$ For an expansion of this reading of Donne's poem, see Gary Kuchar, "John Donne and the poetics of belatedness: Typology, trauma, and testimony in An Anatomy of the World", The Poetry of Religious Sorrow in Early Modern England (Cambridge, 2009), pp. 184-215.
} 
this passage: "This booke", writes Hutchinson, "Holds forth ye Pannople of heauenly light" (29) that in John's "darkist solitude ... his soule with God \& heauen acquaints" (21-5). The Word of God succeeds in "Changing his Soule Through ye strong Power of loue" - so that

Into Those glorious Things he sees aboue By [easily] perceiud degrees he went By sweete Humillity begun Th'ascent To perfect Selfe denial rose; Then stept Into Gods strengthening loue \& yt loue kept Him from appostacy \& did aduance To ye next Staire of Cherefull Sufferance In patient meekenesse yet he higher Climbd Then holinesse his mounting Soule subblimd $(22-42)$

Not only is John's ascent upwards "easily" achieved, but it is stopped right at the point of apostasy (implied, here, as the vice of impatience) by the Puritan virtues of humility, selfdenial, and meekness. John's elevation to a holy state is figured in terms even more absolute in Elegy 1, as Hutchinson again borrows the trope of alchemical purification to foretell of John's miraculous resurrection by the "Sacred flame" (13) of God:

When this pure flame had burnt away ye drosse

It made him rich by Vniuersall Losse

Out of ye Pile a Pheanix did arise

Enlightend with quick penetrating Eies (23-6)

With both John Hutchinson and Elizabeth Drury figured in these ineffable terms, their respective elegaic landscapes cannot but be rendered, in a melancholy chiaroscuro, more painfully dark in contrast. Indeed, the breathless moments of remembrance given above read like epiphanies in the most religious of senses, recalling also Plato's divine frenzy, the "recollection of an otherworldly realm of supracelestial light recaptured only in moments of ecstasy" (Klibansky, Panofsky \& Sax1 41). The corollary of any experience of gestalt, however, is the relativisation of mundane reality. For Donne and Hutchinson, the experience of a bliss reminiscent of Paradise (whether personal, or hypothetical) is 
contingent on the existence of their now-lost objects. ${ }^{117}$ Both poets experience the world of Ideas only through the elegiac objects they position as symbols of it. Whilst Drury and John Hutchinson journey to districts salvific, Donne and Hutchinson anchor themselves to a fallen earth which can only sketch in shadows the original Forms that have been wrenched away. This sense of exile is native to allegory: "as a mode of expression", Bainard Cowan writes, "[allegory] arises in perpetual response to the human condition of being exiled from the truth that it would embrace" (114). ${ }^{118}$

Donne positions Drury as a sun-like figure in possession of the magnetic power "To draw and fasten sundered parts in one" (222). Without her cohering puissance, "The element of fire is quite put out, / The Sun is lost, and the Earth, and no man's wit / Can well direct him where to look for it" (206-8). Left bereft of its heliographic centre, the poetic universe of Donne's poem dislocates in quite the same way as Earth following Adam and Eve's Fall, said to bleed, mourn, have fits, and be generally "Quite out of joint" (192). Hutchinson's eleventh elegy depicts a comparable fall, as the poet turns from painful remembrance of a mansion buoyed by marital bliss, to a scene of domestic ruin:

\begin{abstract}
But Soone Those Actors left an empty stage The Nobler liuing guests $y^{t}$ filld those roomes Are now withdrawne \& shut vpe in their Tombs Even I whoe here did once in Splendor burne Doe now a dimme expiring snuffe returne [There] twas ([I sighd]) ah me twas euen Their Philocles breath $\mathrm{p}^{\mathrm{r}}$ fumed $\&$ warmd $\mathrm{y}^{\mathrm{e}}$ ayre That circled me; $\mathrm{w}^{\text {:h }}$ whilst he did respire Carried into my soule Life light \& fire But Since Pale death Those dores of motion seald My Joys Stand Still like streame $\mathrm{w}^{\text {th }}$ Ice Congeald No day Those amorous whispers can restore
\end{abstract}

\footnotetext{
${ }^{117}$ Much has been made of the seeming extravagance of Donne's grief for a "not particularly remarkable girl whom [he] never knew" (see Zailig Pollock, "'The Object, and the Wit': The Smell of Donne's 'First Anniversary'”, English Literary Renaissance, vol. 13, no. 3, 1983, pp. 301-318), p. 305. The distance between Donne's lost object and Hutchinson's is an obvious point of difference between their respective elegies.

${ }^{118}$ Cowan goes on: "Difficulty, above all, witnesses to the fact that there is no continuous passage from phenomena to the transcendent realm of ideas, that an unbridgeable gulf separates them" (114-5).
} 
[No] wounded ayre can heale me any more

Here kind instructions did I oft attend

Here a true merror Stood a faithfull friend

That taught me how to pollish $\mathrm{y}^{\mathrm{e}}$ rude masse

And dresse my Soule in That nere flattring glasse

But Sorrow age death rewin hath destroyd

Whatere I here or any elce where Enjoyd (24-42)

Elegy 11 reads as if ravaged by an iconoclast, house stripped of the ornament and polish which made it (perhaps too naively) an Eden on earth. The outlandish emptiness of the household after its master's passing is insistently conflated with Hutchinson's own interior, affective space, as we discern once again the resistance to consolation that so distinguishes her "Elegies". Refusing even the constant of daylight ("No day Those amorous whispers can restore"), Hutchinson creates the "nocturnal world" (Wiseman 207) which scrims her elegies. The memory traces of John's "Life light \& fire" become the shadow-casting sources of illumination which spill over, as above, into scenes of utter solitude, defilement, and stasis. With the salvific light of the Bible in reach, John's earthly gaol was no literal prison; the Hutchinson mansion after his death, on the other hand, has bars all around. ${ }^{119}$

Noteworthy about the allegorical vista of Elegy 11, moreover, is Hutchinson's subtle distinction at line 35 between her own and her departed spouse's experiences of death. "Pale death", reads the line, "Those dores of motion seald". "Pale" is a favourite word for Hutchinson throughout the "Elegies". When used to describe death, it approximates the meaning of "type" in Christian usage, presaging future fulfilment in the form of mortal death's antitype. To be pale, then, is to be in a posture of expectation over fulfilment (Lewalski 142). By this definition, all mortal death is "pale", is incomplete, until the raising of mankind on Judgment Day. This applies even to the death of John, who notwithstanding Elegy 7's euphoric vision of sublimation, is doctrinally tied to the

\footnotetext{
${ }^{119}$ Cf. Julius Rubin: "The Protestant Reformation built a prison in which believers chose to live" (Religious Melancholy 3).
} 
earth until the final Resurrection. There are multiple degrees, however, to this typology of postlapsarian death. John, because on the other side of the threshold separating literal existence from non-existence, is a world closer to regaining Paradise, and his martyr-like sacrifice to the Republican cause edges him yet closer to God. Hutchinson repeatedly points to her husband's readiness for the Second Coming of Christ in the elegies she pens for his headstone, emphasizing in these epitaphical verses the ideal state of matter that John enjoys following his mortal death. Consider "An Epitaph": "This weeping Stone doth his deare reliques hide / Waiting The blessed day when our Great King / Shall new Life to his Martiers Cold dust bring" (18-20). Strengthening this presentation of John's remains as in a mere posture of death, soon to be revived and regenerated, is Hutchinson's reference in another of her epitaphs to "The Consecrated Attoms sleeping here" ("Elegy $11 " 1$, emphasis mine). ${ }^{120}$

By representing John's posthumous condition as a kind of auspicious dormancy, Lucy reserves for him a different allegorical realm than the one she finds herself trapped in. John, we have seen, is just one apocalyptic event away from full restoration. His wife, conversely, endures a painfully underdeveloped typology of mortality in which she can only register (and, mirror-like, reflect) death, never to experience it herself. John's posthumous pale is one of light and allegory, but it is highly exclusive, a caveat that Hutchinson acknowledges when in the Memoirs she writes of her husband's "being taken into that region of light which admitts of none", whilst she is left to "vani[sh] into nothing" (33) . Despite Lucy's binding herself to him so closely, John cannot bear her with him over the boundary that separates the fallen world and its inferior copies from that of the divine. If, in other words, John is the type of salvific death - the equivalent of

${ }^{120}$ Recall, too, the line in Elegy 1: "My light is quite extinct where he but sleepes" (6). 
Eden, in that he is nearly but not quite tantamount to Heaven - then Lucy is the melancholy type of John, a derivative layer of shade once more over.

\section{Conclusion}

In the surviving manuscript copy of the "Elegies", a rogue poem appears between the second and third elegies. Headed "These verses transcribd out of my other Book", this short poem is in fact Eve's postlapsarian lament from Order and Disorder, lifted out of that biblical context and carrying all of its lapse-related resonances into Hutchinson's meditations on her husband's death. Eve's lament is laced with self-hatred, suicidal sentiment, and spousal guilt. Despite having just received the redemption clause from God (the edict that woman shall "Recover all the hurt of her first fall / When, in mysterious manner, from her womb / Her father, brother, husband, son shall come" [2268]), Eve sees no remedy to her fate but in a death she is not granted:

\footnotetext{
ah! why doth death its latest stroke delay if we must Leue $\mathrm{y}^{\mathrm{e}}$ light, why do we stay? by slow degrees, more paynefully to die, $\&$ languish in a Long calamitye.

Have we not lost by one false cheating Sin, All peace $\mathrm{w}^{\text {th }}$ out all sweet Repose within? Is there a pleasure yet $\mathrm{y}^{\mathrm{t}}$ life can shew, doth not each moment multiply our woe? (1-8)
}

Here, as in Elegy 11, it is not death itself which Hutchinson's speaker fears. Indeed, she welcomes it, as the first step to reunification with the Eden she is to lose. What horrifies Hutchinson instead are the "slow degrees" of increasing woe and languishment that stand between fallen (wo)man and the sweet release of death. In the fallen world, every lived woe is like a stroke of death that does not betoken the "latest". Death constitutes precisely this mocking promise in Elegy 9, "Another Night":

The shades of death hath hemd me round My late Crowne lyes in ye Cold ground And my glories are become Only the trickments of a tombe (53-6) 
Though the ephemerality of earthly joy and life is the only structuring rule of the elegies, this transience is, paradoxically, not the poet's own, and so she lives a Sibyl amidst a poetic wasteland that records the mere "shades of death" (these being, apparently, the degrees between her former "glories" and her current fallen state). Her elegies thus read, cumulatively, as a facies hippocratica that eternally portends, never achieving its end in concrete non-being. If only the pain of life were as quick to ebb as Hutchinson makes it out to be in her theological treatise:

Man that is borne of a woman (sayth holy job) is of few dayes and full of trouble He cometh forth like a flower and is cut downe, he flies also as a shadow, and continueth not. He vanishes like sleepe in the morning; is like grasse that growes up and flourishes in the morning, in the evening is cut down \& wither'd, his life passing away as a tale that is told, and as a hasty flijing Post. ("On the Principles of the Christian Religion" 253)

But the Hutchinson of the "Elegies", on the contrary, is locked into a cyclical term of recollection and mourning which pushes resolution - resolution in the form of emancipatory death - further out of sight. In this melancholy world, complaints are on loop, as the speaker yearns for a passage between the earthly and divine (the proximate and the allegorical) realms, yet cannot in all good Christian conscience infringe upon the domain of holy death for which her husband is destined a place. ${ }^{121}$

A sense of lack as severe as that which tears the very centre out of the "Elegies" is, as Francesca Southerden says of Vittorio Sereni's poetry, the cause of a "backward-looking desire, whose point of origin is synonymous with its final destination, in a finite and closed circle - an endless circling of self-destruction" (219). Seventeenth-century writer Alice Sutcliffe's poem "Of our loss by Adam, and our gain by Christ” (1634) perfectly encapsulates this melancholy feeling of backwardness, connecting it quite explicitly to the postlapsarian condition:

Still barren is this world of true content,

${ }^{121}$ See especially Elegy 11: "Me Thoughts That hauing a vast circle run / Hither I came \& where I first begun" (9-10). 
Fruitfull enough in procreating woes, Thorny afflictions towards us are bent,

But certain joys still backwards from us goes;

Who thinks to catch them does a shadow chase,

And like Ixion doth a cloud embrace. (421-5)

The religious poet suffers the dire fate of belonging to a universe that is doomed always to foreshadow, and yet never to fulfil, the promise of a bliss played before. This is certainly the case in Hutchinson's "Elegies", where the typological symbolism at play rids the rendered world of "true content", and irrevocably binds the elegiac speaker to a past paradise which, despite all her poetic labours, resists restoration. For the postlapsarian melancholic, the "overinflated, hyperbolic past" comes to fill "all the dimensions of psychic continuity" (Kristeva 60).

Even for the most fervent of believers, this obsession with the past is a dangerous one, for melancholy affect in the face of such a world-cleaving loss threatens to overwhelm what remains of the subject's belief in cure (soteriological, or otherwise). No theologian would call Hutchinson irreligious for her renunciation of the fallen world in preference of the higher. But the poet's penchant for Neoplatonic imagery and epistemology does not, as Elizabeth ScottBaumann suggests, allow her to better mediate between the visible and invisible realms. ${ }^{122}$ Instead, it so starkly cleaves Hutchinson's pale of being from that of her husband that the first is made a purgatory generative of shades upon shades. The believing Puritan rightly performs her doctrinal duty by measuring the fallen world against what she believes of the higher, and subsequently judging the lower a place of sin, suffering, and limbo. It is the realisation that she cannot bridge the two, however, which lends to Hutchinson's latter elegies the same nihilism that suffuses modern poetry that mourns the death of God. Consider Hutchinson's very last elegy, devastating in its brevity:

Farewell my Joyes

122 "If the Fall from Eden provides a model of loss and disconnection for Hutchinson and [Aemilia] Lanyer, Platonic imagery allows a connection with the object of their praise" (Baumann "Paper Frames" [671]). 


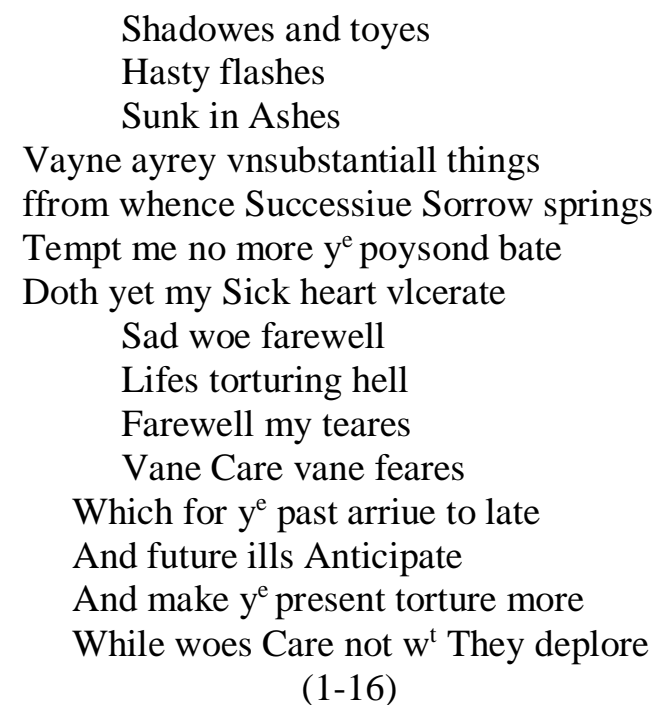

In this, Hutchinson has entirely abandoned the enterprise of regaining Paradise by writing her spousal loss into the larger mythological narrative of the Fall. Indeed, the lost object of John has by Elegy 23 altogether disappeared, and with him the sublime promise of celestial reunification that Hutchinson upholds in many of her elegies. The denigration of "Things below" is unflinching, as she closes off hope of consolation in all directions, from belated past, to ill-foreboding future, to empty present. All that remains is a pure, despondent melancholy which sees loss in every thing.

This mourning for mourning's sake sounds much like the melancholy which some have claimed to permeate postmodernity. And yet both the atheistic brand of melancholy espoused by many of today's philosophers and the seemingly-hopeless affective state that Hutchinson espouses in the "Elegies" are more religious than they may seem. Both, it can be said, pine for a Christian past which is beyond reclamation. For Hutchinson, existence without John comes off badly in the elegies' relativist clash with what used to be, as his loss is conflated with the loss of man's first happiness. For modern nonbelievers, it is the bygone religious episteme itself that constitutes the bliss that cannot be reinstalled. ${ }^{123}$ The sorrow and fear of the

\footnotetext{
${ }^{123}$ Although we try to reclaim it via imitation: John Gray, for example, considers atheism to simply replace God with humanity. In a review of Gray, Terry Eagleton writes of a modern transcendence which is without content, citing the paradigmatic example of "Hollywood spirituality" (see paragraph 5).
} 
postlapsarian melancholic (whether of Hutchinson's age, or ours) cannot, therefore, be wholly attributed, in Burtonic style, to "lov[ing] the world too much; God too little", but rather to that subject's all-too-ardent preservation of a divine yesteryear which the fallen world can only render in shadows. 


\section{Conclusion}

Hutchinson's final elegy represents her affective nadir, the culmination of the "dark night of the soul" that her poetic series charts. But there is a case to be made for the psychic turn which might chase the hopeless finish of Hutchinson's "Elegies", which might see the darkness of mortal woe sublimed to light. Indeed, one could argue that postlapsarian melancholy is by definition a transient state, the affective waiting-room for a death which will - eventually - arrive. Hutchinson's "dark night of the soul" would become then a necessary purgation, an emptying of the self in order to be filled with God's divine will. "Only the person who had cleared this inner space", writes Julius Rubin, "could become an empty vessel that would subsequently be filled by the godhead" ("Melancholy" 299). In this reading, the elegies can be seen to project the same prospective vision as T.S. Eliot's “The Wasteland", apparent barrenness revised as a mere blip in a cycle which will, ultimately, revolve its way back to some form of vitality. The "Elegies" would then read more like An Collins' religious lyrics, which sing of cruel April being overcome with "Secret Meditacion and Contemplacion / Of heavenly blis" ("Another Song [The Winter of my infancy]" 54-5), and with hope that "though Spring be lat / Perhaps my Sommerage may be ... beneficiall enough for me" (47-50).

Even if Hutchinson prophesies no future glory for herself beyond her final elegy, the notion of purgation holds much currency in the discussion of literary melancholy. No matter how impoverished the state of the psyche, writing is a vital therapy for the 
dispositional melancholic. ${ }^{124}$ It is perhaps, as Nietzsche writes of Dionysian man, the only therapy available to the melancholic imprisoned in thought: "at this juncture, when the will is most imperilled, art approaches, as a redeeming and healing enchantress; she alone may transform these horrible reflections on the terror and absurdity of existence into representations with which man (sic) may live" (23). As Nietzsche's remark suggests, the making of art is for the melancholic not a wholesale cure for world-weariness so much as a satiating act of transformation, an activity which transforms an invisible experience into a thing that is real, has matter. This thing, the melancholic text, has all the hazy edges of the lost object itself. Like all texts, the melancholic text is a written monument, immortalizing its writer's subjectivity so that future generations may resurrect ghosts through words. What distinguishes the artist controlled by melancholy, however, is the already-ghostly nature of their subjectivity. The melancholic writer thus inscribes into their work a personhood "Whose presence, absence, absence presence is" (Sidney “Sonnet 60" 13). ${ }^{125}$

The female melancholic, too, is cursed - or blessed - with this liminality of self. Take An Collins' censorship of her melancholy in Divine Songs, which certainly leaves a sense of emotional personhood wanting. More straightforwardly, Lucy Hutchins on's "Elegies" paint absence in allegorical strokes, her poetic landscape figured as a heap of broken images which have all but lost their ties to divine reality. But the woman melancholic does not exclusively aim to create a piece of art which, recording absence, denies the physical world and the material body. As has been discussed with reference to Hester Pulter, the marmorising melancholic seems willingly to encase herself in the

\footnotetext{
${ }^{124} \mathrm{Cf}$. Freud: "The complex of melancholia behaves like an open wound, drawing to itself cathectic energies ... and emptying the ego until it is totally impoverished" (253). 125 "Blist in [his] curse, and cursed in [his] bliss" (14), the Petrarchan lover of Sidney's Astrophel and Stella shares much in common with the dispositional melancholic.
} 
material, achieving in the process a blending of mind and matter, philosophical activity and corporeal existence. This monist view of melancholy may involve the body, but it is distinct from the culturally-theorized disorder which located Renaissance woman's suffering in "her restless and greedy body rather than her restless and creative mind" (Hodgkin Voicing Women 75). Indeed, if this thesis arrives at any sweeping conclusion, it is that when - if - early modern woman writes melancholy from her body, or when she concretizes grief objectally, she in no way excludes herself from the "category of genius" (Radden Moody Minds 47) that attended male melancholy.

As has been illustrated across this thesis' three chapters, melancholy is for the woman speaker less a similizing structure than a many-forked path to religious, psychological, artistic, and philosophical expression. The argument of my first chapter effectively problematized the notion of the female melancholic's straightforward "expression" altogether, suggesting that neither the uninhibited complaint of Shakespeare's madwomen nor Collins' confessional discourse is designed to conjure a substantial melancholy subjectivity. From verbal stoicism to material stoicism, Chapter Two argued for a form of maternal grief-cum-melancholy in three canonical works of Jacobean drama, and in the poetry of Hester Pulter. The analogical doctrines of Ovidian metamorphosis and alchemical change were posed to coalesce around literary events involving female loss, thereby monumentalizing women's transitive grief into melancholy. Progressing further through the seventeenth century, my third and final chapter explored the "Elegies" of Lucy Hutchinson. Drawing on Walter Benjamin's notion of allegory as inherently melancholic, I demonstrated how Hutchinson fuses Neoplatonist and Christian typological thought to figure fallen reality as a mere melancholy shadow. 
So irreducible is the matter of female melancholy that it opens up myriad avenues for scholarly discussion beyond those that I have chosen to pursue. ${ }^{126}$ Further attention needs be drawn to the kinds of conceptual engineering that female speakers (and especially women writers) perform when they adopt melancholy as an affect of their own - when the writing woman moves to displace, in the words of Helene Cix ous, the place she holds within man's discourse, to "explode it, overturn it, grab it, make it hers, take it in, take it into her woman's mouth, bite its tongue with her woman's teeth, make up her own tongue to get inside it" (196). This is a project which will necessarily go further than I have, beyond the few short centuries of the Renaissance, and beyond the delimited space and language of early modern England. For now, though, my project attests that there is much matter to early modern female melancholy, and many a "foul ... vapour" (Ham. 2.2.263) still to be purged.

\footnotetext{
${ }^{126}$ These avenues include: the manifestation of melancholy in the writings of self-declared melancholics such as Margaret Cavendish and Mary Wroth; the place of the female or the feminine within male melancholy; and the way in which melancholy is replaced by, or is reinvented as, the gendered illnesses of hysteria and neurasthenia as one literary period rolls over into another.
} 


\section{Appendix}

Table A: References in the Jailer's Daughter's speech:

\begin{tabular}{|c|c|}
\hline \multicolumn{2}{|c|}{ Jailer's Daughter } \\
\hline Reference & Referent \\
\hline $\begin{array}{l}\text { Song: "For I'll cut my green coat a foot above } \\
\text { my knee" (3.4.19) }\end{array}$ & From "Child Waters" \\
\hline $\begin{array}{l}\text {... "He s'buy me a white cut forth for to ride/ } \\
\text { And I'll go seek him through the world that is so } \\
\text { wide" (3.4.22-3) }\end{array}$ & $\begin{array}{l}\text { "Related to some version of "Lord Thomas and } \\
\text { Fair Annet" (Child ballad 73), according to } \\
\text { Waith }\end{array}$ \\
\hline $\begin{array}{l}\text { (3... "O, for a prick now like a nightingale" } \\
(3.4 .25)\end{array}$ & Philomel myth | \\
\hline .... "I shall sleep like a top else" (3.4.26) & Proverbial \\
\hline $\begin{array}{l}\text { Song: "This George Alow came from the south" } \\
\text { (3.5.54) }\end{array}$ & $\begin{array}{l}\text { "George Aloo and the Swiftstake", } 1611 \\
\text { popular ballad }\end{array}$ \\
\hline Song: "The one he scid if was an owl" (3.5.63) & $\begin{array}{l}\text { Likely an earlier ballad - named "The Three } \\
\text { Huntsmen" in Opie's collection of folksongs }\end{array}$ \\
\hline $\begin{array}{l}\text { "Sirrah tinker, / Stop no more holes but what } \\
\text { you should" (3.5.76-7) }\end{array}$ & $\begin{array}{l}\text { Part of children's counting rhyme "Tinker, tailor, } \\
\text { soldier, sailor" }\end{array}$ \\
\hline $\begin{array}{l}\text { "let him play / Chi passa oth'bells and bones" } \\
(3.5 .78-9)\end{array}$ & Popular song - "Chi passa per questa strada" \\
\hline $\begin{array}{l}\text { The Wooer reporting:] "Then she sung / Nothing } \\
\text { but 'Willow, willow, willow'" (4.1.80) }\end{array}$ & $\begin{array}{l}\text { Popular burden for songs in } 16^{\text {th }} \mathrm{C} \text { - Willow, } \\
\text { Willow (also sung by Desdemona, Othello } \\
4.3 .40-52 \text { ) }\end{array}$ \\
\hline $\begin{array}{l}\text { Song: "May you never more enjoy the light" } \\
\text { (4.1.103) }\end{array}$ & Unknown \\
\hline $\begin{array}{l}\text { "I can sing 'The Broom' / And 'Bonny Robin'"' } \\
\text { (4.1.108-9) }\end{array}$ & $\begin{array}{l}\text { "Bonny Sweet Robin" and "The Broom" } \\
\text { (possibly a version of All Flowers of the Broom, a } \\
\text { dance tune) }\end{array}$ \\
\hline Song: "O fair, O sweet, \&c" (4.1.113) & Seventh of Sidney's Certain Sonnets \\
\hline $\begin{array}{l}\text { "He'll tickle'f up / In two hours it his hand be in" } \\
(4.1 .137-8)\end{array}$ & Proverbial \\
\hline $\begin{array}{l}\text { Song: "When Cynthia with her borrowed light, } \\
\text { \&c" (4.2.155) }\end{array}$ & $\begin{array}{l}\text { Unknown- but line appears in Thomas } \\
\text { Sackville's } 1563 \text { The Mirror for Magistrates }\end{array}$ \\
\hline $\begin{array}{l}\text { "The burden on' } \mathrm{l} \text { was 'down- } \mathrm{a} \text {, down-a'" ( } 4.2 .9 \text { - } \\
\text { 10) }\end{array}$ & Popular refrain \\
\hline "pick flowers with Proserpine" (4.3.29) & Classical myth \\
\hline $\begin{array}{l}\text { Song: "I will be true, my stars, my fate, } 8 \mathrm{c} \text { " } \\
\text { (4.3.46) }\end{array}$ & Unknown \\
\hline $\begin{array}{l}\text { "And gallops to the tune of "Light o'love'" } \\
(5.2 .54)\end{array}$ & $\begin{array}{l}\text { Dance tune mentioned also in Much Ado } \\
\text { About Nothing and The Two Gentlemen of } \\
\text { Verona }\end{array}$ \\
\hline $\begin{array}{l}\text { "How far is' now to th'end o'th' world, my } \\
\text { masters?" (5.2.76) }\end{array}$ & Proverbial \\
\hline
\end{tabular}

Table B: References in Ophelia's speech:

\begin{tabular}{|c|c|}
\hline \multicolumn{2}{|c|}{ Ophelia } \\
\hline Reference & Referent \\
\hline $\begin{array}{l}\text { Song: "How should I your true love } \\
\text { know [...]" (4.5.23) }\end{array}$ & $16^{\text {th }} \mathrm{C}$ Walsingham ballad \\
\hline $\begin{array}{l}\text { "They say the owl was a baker's } \\
\text { daughter" (42) }\end{array}$ & Popular folktale \\
\hline $\begin{array}{l}\text { Song: "Tomorrow is Saint } \\
\text { Valentine's day" (4.5.48) }\end{array}$ & Unknown \\
\hline $\begin{array}{l}\text { Song: "By Gis and by Saint Charity" } \\
(4.5 .58)\end{array}$ & $\begin{array}{l}\text { Unknown (but similar to invocations } \\
\text { to Saint Charity as found in } \\
\text { Spenser) }\end{array}$ \\
\hline $\begin{array}{l}\text { Song: "They bore him bare-faced } \\
\text { on the bier / Hey nonny" (4.5.164- } \\
\text { 5) }\end{array}$ & $\begin{array}{l}\text { "hey nonny" a common burden in } \\
\text { love ditties }\end{array}$ \\
\hline $\begin{array}{l}\text { "You must sing a-down a-down" } \\
(4.5 .170)\end{array}$ & $\begin{array}{l}\text { Popular refrain - cf. The } \\
\text { Shoemaker's Holiday, England's } \\
\text { Helicon }\end{array}$ \\
\hline $\begin{array}{l}\text { "It was the false steward that stole } \\
\text { his master's daughter" (4.5.171-2) }\end{array}$ & $\begin{array}{l}\text { "false steward" a suspected (but } \\
\text { sofar undiscovered) reference }\end{array}$ \\
\hline $\begin{array}{l}\text { Flowers: "There's rosemary, that's } \\
\text { for remembrance }[\ldots] \text { " }(4.5 .174-5 \text {, } \\
177-181)\end{array}$ & $\begin{array}{l}\text { Various cultural associations - } \\
\text { flattery, ingratitude, sorrow, } \\
\text { springtime }\end{array}$ \\
\hline $\begin{array}{l}\text { Song: "For bonny sweet Robin is all } \\
\text { my joy" (4.5.182) }\end{array}$ & $\begin{array}{l}\text { "Bonny Sweet Robin " - popular } \\
\text { ballad }\end{array}$ \\
\hline $\begin{array}{l}\text { Song: "And will a not come } \\
\text { again?" (4.5.185) }\end{array}$ & Unknown \\
\hline
\end{tabular}


Figure 6: References in An Collins' Divine Songs and Meditacions

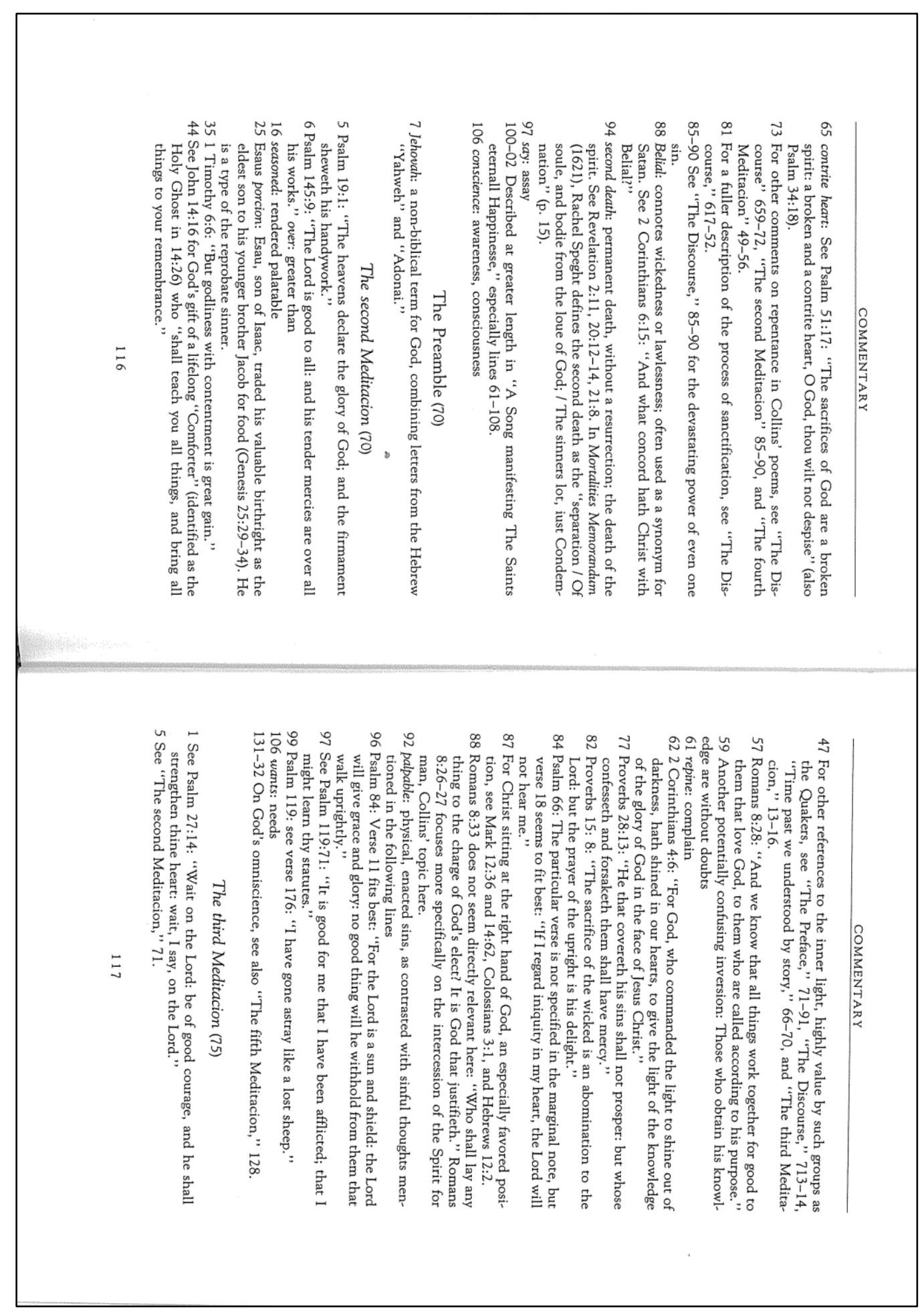

[From Gottlieb, pp. 116-7] 


\section{Works Cited}

Abraham, Lyndy. A Dictionary of Alchemical Imagery. Cambridge University Press, 1998.

---. Marvell \& Alchemy. Scolar Press, 1990.

Anderson, Penelope. "Lucy Hutchinson's Sodom and the backward glance of feminist queer temporality". The Seventeenth Century, vol. 30, no. 2, 2015, pp. 249-264.

Archer, Jayne. "A 'Perfect Circle'? Alchemy in the Poetry of Hester Pulter". Literature Compass, vol. 2, no. 1, 2005, pp. 1-14.

Bakhtin, Mikhail. The Dialogic Imagination: Four Essays by M.M. Bakhtin. Translated by Michael Holquist (also editor) and Caryl Emerson, University of Texas Press, 1991.

Bayer, Penny. "From Kitchen Hearth to Learned Paracelsianism: Women and Alchemy in the Renaissance”. Mystical Metal of Gold: Essays on Alchemy and Renaissance Culture, edited by Stanton J. Linden, AMS Press, 2007, pp. 365386.

Benjamin, Walter. The Origin of German Tragic Drama. Translated by John Osborne, Verso, 1977.

Bradley, A.C. Shakespearean Tragedy. $7^{\text {th }}$ ed. Macmillan, 1992.

Breitenberg, Mark. Anxious Masculinity in Early Modern England. Cambridge University Press, 1996.

Britland, Karen. "Conspiring with Friends: Hester Pulter's Poetry and the Stanley Family at Cumberlow Green”. The Review of English Studies, New Series, pp. $1-23$.

Brownlee, Victoria. Biblical Readings of Literary Writing in Early Modern England, 1558-1625. Oxford University Press, 2018.

Burton, Robert. The Anatomy of Melancholy. Edited by A.R. Shilletto, G. Bell and Sons, 1912. 3 vols.

Chalk, Brian. Monuments and Literary Posterity in Early Modern Drama. Cambridge University Press, 2015.

Chauncy, Henry. The Historical Antiquities of Hertfordshire. J.M. Mullinger, London, 1826. 
Chedgzoy, Kate. Women's Writing in the British Atlantic World: Memory, Place, and History, 1550-1700. Cambridge University Press, 2007.

Christian, Stefan Graham. The poems of Lady Hester Pulter (1605?-1678): An Annotated Edition. PhD Thesis, University of Massachusetts Amherst, 2012.

Cixous, Celene. “The Laugh of the Medusa”. Signs, vol. 1, no. 4, 1976, pp. 875-893. Clarke, Danielle and Marie-Louise Coolahan. "Gender, Reception, and Form: Early Modern Women and the Making of Verse". The Work of Form: Poetics and Materiality in Early Modern Culture, edited by Elizabeth Scott-Baumann and Ben Burton, Oxford University Press, 2014, pp. 145-162.

Clark, Sandra. “The Broadside Ballad and the Woman's Voice”, Debating Gender in Early Modern England, 1500-1700, edited by Christina Malcomson and Mihoko Sizuki, Palgrave Macmillan, 2002, pp. 103-120.

Collins, An. Divine Songs and Meditacions. Edited by Sidney Gottlieb, Medieval \& Renaissance Texts \& Studies, 1996.

Connolly, Ruth. “Hester Pulter's Childbirth Poetics”. Women's Writing, 2016, pp. 122.

Cowan, Bainard. "Walter Benjamin's Theory of Allegory". New German Critique, no. 22 (Special Issue on Modernism), 1981, pp. 109-122.

Cummings, Brian. The Literary Culture of the Reformation: Grammar and Grace. Oxford University Press, 2002.

Daniel, Drew. The Melancholy Assemblage: Affect and Epistemology in the English Renaissance. Fordham University Press, 2013.

De Grazia, Margreta. "Soliloquies and Wages in the Age of Emergent Consciousness". Textual Practice 9, 1995, pp. 67-92.

Derrida, Jacques. "Signature, Event, Context”. Margins of Philosophy, translated by Alan Bass, University of Chicago Press, 1982, pp. 309-330.

Dixon, Laurinda S. The Dark Side of Genius: The Melancholic Persona in Art, ca. 1500-1700. Penn State University Press, 2015.

Donne, John. Selected Letters. Edited by P.M. Oliver, Routledge, 2002.

---. The Poems of John Donne. Edited by Robin Robbins, Longman, 2008. 2 vols.

Eagleton, Terry. "Seven Types of Atheism by John Gray review - is every atheist an inverted believer?". The Guardian, 11 April 2018, www.theguardian.com

Eardley, Alice. “'Saturn (whose aspects soe sads my soule)': Lady Hester Pulter's feminine melancholic genius". New Ways of Looking at Old Texts, IV: Papers 
of the Renaissance English Text Society, 2002-2006, edited by Michael Denbo, ACMRS, pp. 239-254.

Eliot, Thomas Stearns. "Hamlet and His Problems". Selected Essays, Harcourt, Brace and Company, 1932, pp. 121-6.

Enterline, Lynn. Shakespeare's Schoolroom: Rhetoric, Discipline, Emotion. University of Pennsylvania Press, 2012.

Felski, Rita. Beyond Feminist Aesthetics. Harvard University Press, 1989.

Ferrand, Jacques. Erotomania: or, A Treatise Discoursing of the Essence, Causes, Symptomes, Prognosticks, and Cure of Love, or Erotique Melancholy. Oxford, 1640. Early English Books Online, eebo.chadwyck.com

Fish, Stanley. "Thou thyself art the subject of my discourse: Democritus Junior to the Reader". Self-Consuming Artifacts, University of Berkeley Press, 1972, pp. 303-352.

Flatley, Jonathan. Affective Mapping: Melancholia and the Politics of Modernism. Harvard University Press, 2008.

Foucault, Michel. The History of Sexuality, Volume One: An Introduction. Translated by Richard Hurley, Penguin, 1990.

---. Madness and Civilisation: A History of Insanity in the Age of Reason. Translated by Richard Howard, Routledge, 2005.

---. The Order of Things. Routledge, 2002.

Fox, Ruth A. The Tangled Chain: The Structure of Disorder in the Anatomy of Melancholy. University of California Press, 1976.

Freud, Sigmund. "Mourning and Melancholia". The Complete Psychological Works of Sigmund Freud: Volume XIV (1914-16), translated by James Strachey in collaboration with Anna Freud, Hogarth Press, 1957, pp. 243-258.

Gilbert, Sandra and Susan Gubar. "Sexual Linguistics: Gender, Language, Sexuality". New Literary History, vol. 16, no. 3, 1985, pp. 515-543.

Goethe, Johann Wolfgang von. Wilhelm Meister's Apprenticeship, Volume 2. Translated by Thomas Carlyle, Oliver \& Boyd, 1824, pp. 90-91.

Goldberg, Jonathan. James I and the Politics of Literature. Johns Hopkins University Press, 1983.

---. Voice Terminal Echo: Postmodernism and English Renaissance Texts. Methuen, 1986. 
Goodland, Katharine. Female Mourning and Tragedy in Medieval and Renaissance English Drama. Ashgate, 2006.

Harman, Barbara Leah. Costly Monuments: Representations of the Self in George Herbert's Poetry. Harvard University Press, 1982.

Hartmann, Franz. The Life \& Doctrines of Phillippus Theophrastus. London, 1887.

Herbert, George. The Complete English Works. Edited by Ann Pasternak Slater, Everyman's Library, 1994.

Hodgkin, Katharine. "Dionys Fitzherbert and the Anatomy of Madness". Voicing Women: Gender and Sexuality in Early Modern Writing, edited by Kate Chedgzoy, Melanie Hansen and Suzanne Trill, Duquesne University Press, 1997, pp. 69-92.

---. "Scurvy Vapours and the Devil's Claw: Religion and the Body in SeventeenthCentury Women's Melancholy". Studies in the Literary Imagination, vol. 44, no. 2,2011 , pp. 1-21.

Hodgson, Elizabeth. Grief and Women Writers in the English Renaissance. Cambridge University Press, 2015.

Hutchinson, Lucy. Memoirs of the Life of Colonel Hutchinson. Edited by James Sutherland, Oxford University Press, 1973.

---. 1679. Order and Disorder. Edited by David Norbrook, 2001.

---. The Works of Lucy Hutchinson, Vol. II: Theological Writings and Translations.

Edited by Elizabeth C. Clarke, David Norbrook, and Jane Stevenson, Oxford University Press, 2018.

Jehlen, Myra. “Archimedes and the Paradox of Feminist Criticism”. Signs, vol. 6, no. 4, 1981, pp. 575-601.

Jung, Carl. Psychology and Alchemy. The Collected Works of C.G. Jung, vol.12. Edited by Gerhard Adler and R.F.C. Hull, Princeton University Press, 1968.

Kemp, Anthony. The Estrangement of the Past: A Study in the Origins of Modern Historical Consciousness. Oxford University Press, 1991.

Kern Paster, Gail. Humouring the Body: Emotions and the Shakespearean Stage. University of Chicago Press, 2004.

Klibansky, Raymond, Erwin Panofsky and Fritz Saxl. Saturn and Melancholy. Nelson, 1964.

Kristeva, Julia. Black Sun: Studies in Depression and Melancholia. Translated by Leon S. Roudiez, Columbia University Press, 2009. 
Kuchar, Gary. The Poetry of Religious Sorrow in Early Modern England. Cambridge University Press, 2009.

Laing, R.D. The Divided Self: An Existential Study in Sanity and Madness, Volume 1. Routledge, 2006.

Lewalski, Barbara. Protestant Poetics and the Seventeenth-Century Religious Lyric. Princeton University Press, 1979.

Lewis, C.S. A Preface to Paradise Lost. Oxford University Press, 1942.

Linden, Stanton J., editor. The Alchemy Reader: From Hermes Trismegistus to Isaac Newton. Cambridge University Press, 2003.

Longfellow, Erica. Women and Religious Writing in Early Modern England. Cambridge University Press, 2004.

Lopez, Jeremy. "Reviewing Ophelia". The Afterlife of Ophelia, edited by K.L. Peterson and D. Williams, Palgrave, 2012, pp. 29-41.

Luther, Martin. Commentary on Romans. Translated by J. Theodore Mueller, Kregel, 2004.

Mansfield, Katherine. Journal of Katherine Mansfield. Edited by John Middleton Murray, Constable \& Company, 1928.

Marvell, Andrew. The Poems of Andrew Marvell (Revised ed.). Edited by Nigel Smith, Longman, 2007.

Maus, Katharine. Inwardness and Theater in the English Renaissance. University of Chicago Press, 1995.

Milton, John. Paradise Lost. Edited by Gordon Teskey, Norton, 2005.

---. The Complete Shorter Poems (2 $2^{\text {nd }}$ ed). Edited by John Carey, Longman, 2007.

Molekamp, Femke. Women and the Bible in Early Modern England: Religious Reading and Writing. Oxford University Press, 2013.

Mosès, Stephane. "Metaphors of Origin: Ideas, Names, Stars". The Angel of History: Rosenzweig, Benjamin, Scholem, translated by Barbara Harshav, Stanford University Press, 2009.

Neely, Carol Thomas. Distracted Subjects: Madness and Gender in Shakespeare and Early Modern Culture. Cornell University Press, 2004.

---. “Documents in Madness': Reading Madness and Gender in Shakespeare's Tragedies and Early Modern Culture". Shakespeare Quarterly, vol. 42, no. 3, 1991, pp. 315-338. 
Neill, Michael. Issues of Death: Mortality and Identity in English Renaissance Tragedy. Oxford University Press, 1997.

Nietzsche, Friedrich. The Birth of Tragedy. Translated by Clifton P. Fadiman, Dover, 1995.

Norbrook, David. 'Lucy Hutchinson's 'Elegies' and the Situation of the Republican Woman Writer (with text)". English Literary Renaissance, vol. 27, no. 3, 1997, pp. 468-521.

---. "Lucy Hutchinson: Theology, Gender, and Translation". Seventeenth Century, vol. 30, no. 2, pp. 139-162.

Norcliffe, Mary Eleanor. "Garden and Antigarden in the Song of Songs and Divine Songs and Meditacions". An Collins and the Historical Imagination, edited by W. Scott Howard, Routledge, 2014, pp. 87-104.

Ovid. Metamorphoses. Translated by Arthur Golding (c. 1565), edited by Madeleine Forey, Johns Hopkins University Press, 2002.

Pensky, Max. Melancholy Dialectics and the Play of Mourning. University of Massachusetts Press, 1993.

Phillippy, Patricia. “'Chain'd up in Alabaster': Awakening Remembrance in The Winter's Tale and Comus". Shaping Remembrance from Shakespeare to Milton, Cambridge University Press, 2018, pp. 190-227.

---. "The Mat[t]er of Death: The Defense of Eve and the Female Ars Moriendi". Debating Gender in Early Modern England, 1500-1700, edited by Christina Malcolmson and Mihoko Suzuki, Palgrave Macmillan, 2002, pp. 142-160.

Price, Bronwen. "The 'image of her mind': Self, Dissent, and Femininity in Divine Songs and Meditacions". An Collins and the Historical Imagination, edited by W. Scott Howard, Ashgate, 2014, pp. 155-170.

---."Women's Poetry 1550-1700: "not Unfit to be Read"”. A Companion to Early Modern Women's Writing, edited by Anita Pachecho, 2002, pp. 282-302.

Pulter, Hester. Poems, Emblems, and The Unfortunate Florinda. Edited by Alice Eardley, Centre for Reformation and Renaissance Studies, 2014.

Radden, Jennifer. Melancholic Habits: Burton's Anatomy \& the Mind Sciences. Oxford University Press, 2006.

---. Moody Minds Distempered: Essays on Melancholy and Depression. Oxford University Press, 2009.

---, editor. The Nature of Melancholy. Oxford University Press, 2000. 
Reed, Robert R. Bedlam on the Jacobean Stage. Harvard University Press, 1952.

Ricoeur, Paul. Memory, History, Forgetting. University of Chicago Press, 2004.

Rosenberg, Marvin. The Masks of Hamlet. University of Delaware Press, 1992.

Ross, Sarah C.E. “'I see our nere, to be reenterd paradice': Lucy Hutchinson's

'Elegies' and Order and Disorder'. Women, Poetry, and Politics in

Seventeenth-Century Britain, Oxford University Press, 2015, pp. 174-210.

--- and Elizabeth Scott-Baumann, editors. Women Poets of the English Civil War.

Manchester University Press, 2018.

Rubin, Julius. "Melancholy". The Oxford Handbook of Religion and Emotion, edited

by John Corrigan, Oxford University Press, 2008, pp. 290-309.

---. Religious Melancholy and Protestant Experience in America. Oxford University Press, 1991.

Ryan, Elise Lonich. 'Gardens of Grief: Lucy Hutchinson's 'Elegies', the Garden of Gethsemane, and Formal Uses of Betrayal". Exemplaria, vol. 28, no. 3, pp. 212-229.

Schiesari, Juliana. The Gendering of Melancholia. Cornell University Press, 1992.

Schmidt, Jeremy. Melancholy and the Care of the Soul: Religion, Moral Philosophy and Madness in Early Modern England. Routledge, 2009.

Scott-Baumann, Elizabeth. "Lucy Hutchinson's Elegies, the Country-House Poem, and Female Complaint". Forms of Engagement: Women, Poetry and Culture 1640-1680, Oxford University Press, 2013, pp. 144-170.

---. “'Paper Frames': Lucy Hutchinson's Elegies and the Seventeenth-Century Country House Poem”. Literature Compass, vol. 4, no. 3, 2007, pp. 664-77.

Shakespeare, William. The Norton Shakespeare ( $3^{\text {rd }}$ ed.). Edited by Stephen Greenblatt, Walter Cohen, Suzanne Gossett, Jean E. Howard, Katherine Eisaman Maus, and Gordon McMullen, W.W. Norton, 2016.

Sidney, Philip. Selected Writings. Edited by Philip Dutton, Carcanet, 1987.

Southerden, Francesca. “"Memorie triste', 'passi perduti”: The Melancholy Journey and the Return to Dante". Landscapes of Desire in the Poetry of Vittorio Sereni, Oxford University Press, 2012, pp. 186-258.

Stewart, Stanley. "An Collins: Fiction and Artifact". An Collins and the Historical Imagination, edited by W. Scott Howard, Ashgate, 2014, pp. 155-170.

Sutcliffe, Alice. Meditations of man's mortalitie. Or, A way to true blessednesse. London, 1634. Early English Books Online. eebo.chadwyck.com 
Swiss, Margo and David A. Kent, editors. Speaking Grief in English Literary Culture: Shakespeare to Milton. Duquesne University Press, 2002.

Trevor, Douglas. The Poetics of Melancholy in Early Modern England. Cambridge University Press, 2004.

The Contemporary Parallel Bible: New King James Version, New International Version. Edited by John R. Kohlenberger II, Oxford University Press, 2004.

Vaught, Jennifer C. Masculinity and Emotion in Early Modern English Literature. Ashgate, 2008.

Wall, Wendy. "Temporalities: Preservation, Seasoning and Memorialisation". Recipes for Thought: Knowledge and Taste in the Early Modern English Kitchen, University of Pennsylvania Press, 2015, pp. 167-208.

Walton, Izaak. "The Life of Dr John Donne". Lives of Donne and Herbert, edited by S.C. Roberts, Cambridge University Press, 2014, pp. 1-58.

Webster, John. The Duchess of Malfi. Edited by Michael Neill, Norton, 2015.

Wilcox, Helen. “'A Grain of Glorie': George Herbert and Seventeenth-Century Devotional Lyrics". Writing and the English Renaissance, edited by William Zunder and Suzanne Trill, Longman, 1996, pp. 159-175.

Wiseman, Susan. 'No 'public funerall'? Lucy Hutchinson's elegy, epitaph, monument”. The Seventeenth Century, vol. 30, no. 2, 2015, pp. 207-228.

\section{Figures}

Figure 1, p.5: "Melencolia 1", Metropolitan Museum of Art, www.metmuseum.org/art/collection/search/336228

Figure 2, p.37: “Sir John Everett Millais Bt. Ophelia 1851-2", Tate, www.tate.org.uk/art/artworks/millais-ophelia-n01506

Figure 3, p. 56: "Elizabeth I", (C) 2018 Dean and Chapter of Westminster, www.westminster-abbey.org/abbey-commemorations/royals/elizabeth-i/

Figure 4, p. 59: "Niobe's Rock", Manila History, www.manisahistory.com/niobe50.html

Figure 5, p. 93: "Nottinghamshire Castle Museum Portrait of John Hutchinson", Nottinghamshire History www.nottshistory.org.uk/articles/tts/tts1914/hutchinson1.html 
Figure 6, p. 118: Gottlieb, Commentary to Collins' Divine Songs and Meditacions, Renaissance English Text Society, 1996, pp. 116-7. 